ROSÂNGELA SPAGNOL FEDOCE

MODELO DE GESTÃO DO CONHECIMENTO PARA O SETOR DE INFRAESTRUTURA DE TELECOMUNICAÇÕES

Tese apresentada à Escola Politécnica da Universidade de São Paulo para a obtenção do título de Doutor em Ciências. 
ROSÂNGELA SPAGNOL FEDOCE

\section{MODELO DE GESTÃO DO CONHECIMENTO PARA O SETOR DE INFRAESTRUTURA DE TELECOMUNICAÇÕES}

Tese apresentada à Escola Politécnica da Universidade de São Paulo para a obtenção do título de Doutor em Ciências.

Área de Concentração:

Engenharia de Sistemas

Orientador: Prof. Dr. José Roberto Castilho Piqueira 


\section{Catalogação-na-publicação}

Fedoce, Rosângela Spagnol

Modelo de Gestão do Conhecimento para o Setor de Infraestrutura de Telecomunicações / R. S. Fedoce -- São Paulo, 2016.

$158 \mathrm{p}$.

Tese (Doutorado) - Escola Politécnica da Universidade de São Paulo. Departamento de Engenharia de Sistemas Eletrônicos.

1.Gestão do conhecimento 2.Educação corporativa 3.Tecnologia educacional 4.Comunicação interna 5.Telecomunicações I.Universidade de São Paulo. Escola Politécnica. Departamento de Engenharia de Sistemas Eletrônicos II.t. 
Dedico este trabalho aos meus pais, Rita e Christóvão. 


\section{AGRADECIMENTOS}

Ao professor José Roberto Castilho Piqueira, pela orientação, pela constante motivação, pelo exemplo profissional e pela dedicação incondicional durante todo o doutorado.

Aos professores Cristina Borba, José Reinaldo Silva, Renato de Oliveira Moraes, Romero Tori e Sebastião Squirra, pelos ensinamentos e pela participação ativa em meu processo de desenvolvimento acadêmico.

A todos os colaboradores da Escola Politécnica, em especial, à bibliotecária Ana Maria Badiali, pelo apoio na busca por referências e pela disponibilidade no esclarecimento de dúvidas.

Aos meus pais Rita e Christóvão, irmãos Aline e Júnior, sobrinha Lívia e a todos os familiares, pela motivação e pelo apoio emocional tão essenciais nesta etapa.

Ao meu marido, Leandro, pelo companheirismo e compreensão nesta fase de dedicação à pesquisa.

Aos amigos Carolina Araújo, Cristiane Batistela, Diego Ferruzzo, Itamar lliuk, Marcelo e Natália Schots, pelo apoio e amizade, e a todos que colaboraram, direta ou indiretamente, na execução deste trabalho. 
As organizações que realmente terão sucesso no futuro serão aquelas que descobrirem como cultivar nas pessoas o comprometimento e a capacidade de aprender em todos os níveis da organização. 


\section{RESUMO}

A pesquisa visa a estruturar um modelo de gestão do conhecimento (GC) para a área de infraestrutura de telecomunicações, a partir da análise de dois setores: serviços móveis de valor agregado (SMVA) e implantação e operação e manutenção (O\&M) de equipamentos. A fundamentação teórica baseia-se em um estudo transdisciplinar, que integra GC, educação corporativa (EC), e comunicação interna. Os métodos utilizados são: estudo de caso, realizado na maior integradora brasileira do mercado de SMVA; e pesquisa-ação, desenvolvida na principal empresa de implantação e O\&M de equipamentos de telecomunicações do país. Representantes de operadoras de redes móveis (ORMs), principais clientes de ambas as empresas estudadas, também participaram da pesquisa por meio da aplicação de questionários. Verifica-se que a GC desenvolvida pela integradora resulta em valor agregado a seus serviços e à vantagem competitiva dos demais segmentos do mercado. O setor de SMVA opera sob a lógica da coopetição, consolidando um ecossistema inserido em um contexto de constantes atualizações tecnológicas e modelos de negócio. Assim como a integradora, a empresa de implantação e O\&M também conta com desafios significativos relacionados à dinamicidade do mercado, aos quais se somam o crescimento significativo de seu quadro de colaboradores, em um curto período de tempo; a atuação em diversos estados nacionais; e a necessidade de qualificação profissional, de acordo com a superação tecnológica. A partir da análise de gestão desta empresa, da validação de provas de conceito em grupos de controle e das estratégias verificadas no estudo de caso, propõe-se um modelo de GC para o setor de infraestrutura de telecomunicações, que integra ações de EC e comunicação interna, com destaque para o uso de dispositivos móveis. A proposta principal consiste na conversão de conhecimento tácito em conhecimento explícito, assim como o processo inverso, em um ciclo contínuo de GC, que releva o capital intelectual (Cl). Além de considerar a externalização (tácito para explícito), o modelo engloba a dinâmica da internalização (explícito para tácito), relevando as experiências individuais e as demandas de informação dos colaboradores. Ao detalhar o processo de elaboração do modelo, almeja-se que esse possa ser replicado e/ou alterado por outras organizações com características e desafios semelhantes.

Palavras-chave: Gestão do conhecimento. Educação corporativa. Tecnologia Educacional. Comunicação interna. Telecomunicações. 
The research aims to design a knowledge management (KM) model for the telecommunication infrastructure section from the analysis by analyzing two sectors: mobile value added service (MVAS), and implantation and operation and maintenance (O\&M) of telecommunication equipment. The theoretical review is based on a transdisciplinary study that integrates GC, corporative education, and corporative communication. We conducted a case study in the main Brazilian integrator, and an action research in a large company of implantation and O\&M of telecommunication equipment. Representatives of mobile network operators (MNOs), main customers of the companies studied, have also participated in this research by means of questionnaires application. The KM developed by the integrator is verified to result in added value to its services, and to the competitive advantage of the other market segments. The MVAS sector operates according to the concept of coopetition, consolidating an ecosystem inserted into a context featured by the continuous technological updating and by changes in business models. In the same way as the integrator, the implantation and O\&M company also faces challenges regarding the market dynamic, to which are added the relevant increase of its workforce in a short period of time; the operation in many places of Brazil; and the need of professional qualification according to the technological updating. From the analysis of this company's management, of the validation of proofs of concept in controls groups, and of the strategies verified in the case study, a $\mathrm{KM}$ model is proposed for the telecommunication infrastructure section that integrates actions of corporate education and internal communication, highlighting the use of mobile devices. Its main propose consists in converting tactical knowledge into explicit knowledge, and the inverse process, in a continuous KM cycle, which highlights the intellectual capital (IC). Besides the model taking into account the externalization process (tactical to explicit), it also encompasses the internalization (explicit to tactical) dynamic, considering the individual experiences and the employees' information needs. Detailing the process of the model building, we hope this can be replicated and/or changed by other companies with similar features and challenges.

Keywords: Knowledge management. Corporate education. Educational technology. Internal communication. Telecommunication. 


\section{LISTA DE GRÁFICOS}

Gráfico 1 Regiões de atuação da empresa de implantação e O\&M..........................41

Gráfico 2 Faixa etária dos colaboradores da empresa de implantação e O\&M......42

Gráfico 3 Inteligências múltiplas predominantes entre os colaboradores da

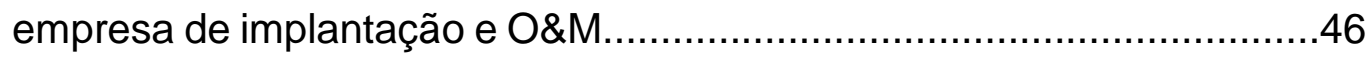

Gráfico 4 Inteligências múltiplas por setores de atuação da empresa de implantação e O\&M.

Gráfico 5 Anos de empresa dos colaboradores da empresa de implantação e O\&M.

Gráfico 6 Escolaridade dos colaboradores da empresa de implantação e O\&M.....56

Gráfico 7 Resultados da pesquisa de satisfação categoria "empresa"....................57

Gráfico 8 Resultados da pesquisa de satisfação categoria "trabalho".....................58

Gráfico 9 Resultados da pesquisa de satisfação categoria "informações institucionais". .59

Gráfico 10 Resultados da pesquisa de satisfação categoria "ambiente de trabalho"

Gráfico 11 Resultados da pesquisa de satisfação categoria "reconhecimento e realização profissional"

Gráfico 12 Resultados da pesquisa de satisfação categoria "aprendizado". 60

Gráfico 13 Resultados da pesquisa de satisfação categoria "gestão"

Gráfico 14 Ações que a empresa poderia considerar para melhorar a comunicação entre os colaboradores.

Gráfico 15 Sugestões e críticas em relação aos treinamentos desenvolvidos pela empresa

Gráfico 16 O que você espera de sua atuação na empresa em relação à satisfação pessoal e profissional.

Gráfico 17 Principais vantagens de se trabalhar na empresa. .66

Gráfico 18 Principais desvantagens de se trabalhar na empresa.

Gráfico 19 Sugestões para que se consolide como uma excelente empresa para se trabalhar. 68

Gráfico 20 Avaliação do conteúdo do curso Integração.........................................75

Gráfico 21 Avaliação da organização do curso Integração........................................76

Gráfico 22 Avaliação dos recursos educacionais do curso Integração.......................76 
Gráfico 23 Avaliação geral do curso Integração..................................................

Gráfico 24 Avaliação do perfil de aprendizagem - curso Integração.........................78

Gráfico 25 Categorias das respostas qualitativas da avaliação de reação

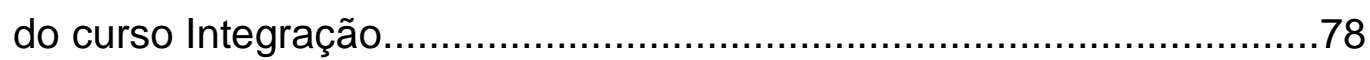

Gráfico 26 Avaliação do conteúdo do curso TCP/IP...........................................

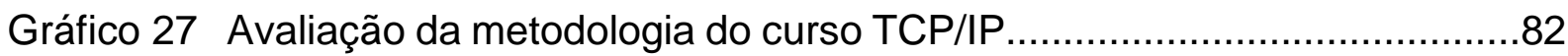

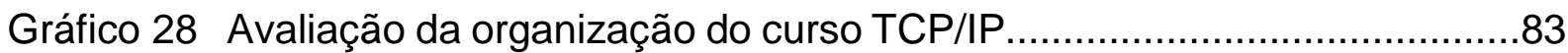

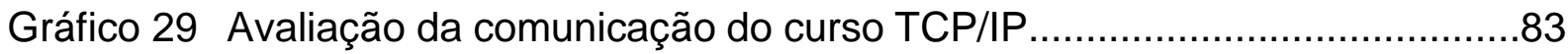

Gráfico 30 Avaliação dos recursos educacionais do curso TCP/IP...........................84

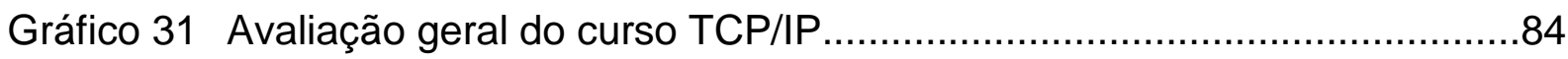

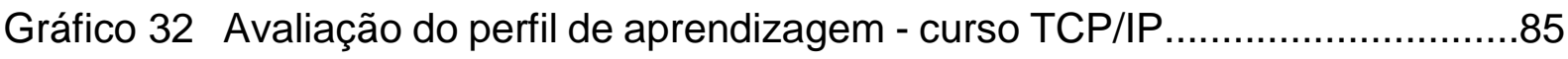

Gráfico 33 Categorias das respostas qualitativas da avaliação de reação do TCP/IP. .85

Gráfico 34 Média final da avaliação conceitual do curso TCP/IP............................86

Gráfico 35 Dispositivos utilizados para acessar os cursos....................................87

Gráfico 36 Frequência com que utiliza informações sobre TCP/IP.........................87

Gráfico 37 Resultados da avaliação de reação do jogo TCP/IP..............................92

Gráfico 38 Principais tipos de informação disponibilizadas pela integradora

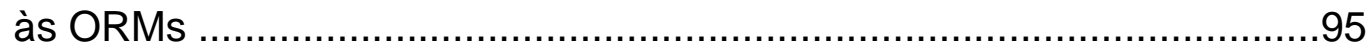

Gráfico 39 O que os dispositivos conectados à Internet e as lojas de aplicativos representam para o negócio das ORMs e para o setor de SMVA brasileiro 


\section{LISTA DE FIGURAS}

Figura 1 Ecossistema padrão de SMVA.............................................

Figura 2 Ecossistema brasileiro de SMVA............................................. 35

Figura 3 Tela principal do site interno acessada de um notebook.....................52

Figura 4 Tela principal do site interno acessada de um smartphone...................52

Figura 5 Descrição dos itens do menu do site interno...................................54

Figura 6 Etapas de produção dos cursos online........................................71

Figura $7 \quad$ Exemplos de telas do curso Integração.........................................74

Figura 8 Exemplos de telas do curso TCP/IP......................................... 81

Figura 9 Tela de abertura e de apresentação do desafio do jogo........................89

Figura 10 Exemplos de questões do jogo TCP/IP......................................90

Figura 11 Telas de encerramento do jogo TCP/IP......................................91

Figura 12 Representação gráfica do modelo de GC para o setor de infraestrutura de telecomunicações..............................................105

Figura $131^{0}$ recorte do modelo de GC: conhecimento tácito...........................106

Figura $142^{\circ}$ recorte do modelo de GC: canal de comunicação interna.................106

Figura $153^{\circ}$ recorte do modelo de GC: conhecimento explícito.........................107

Figura $164^{0}$ recorte do modelo de GC: SEC ............................................... 108 
BI Inteligência de Negócios - do inglês Business Intelligence

Cl Capital Intelectual

EAD Educação a Distância

EC Educação Corporativa

GC Gestão do Conhecimento

IC Inteligência Competitiva

OMV Operadora Móvel Virtual

ORM Operadora de Rede Móvel

O\&M Operação e Manutenção

RH Recursos Humanos

SEC Sistema de Educação Corporativa

SMVA Serviços Móveis de Valor Agregado

TI Tecnologia da Informação

TIC Tecnologias da Informação e Comunicação 


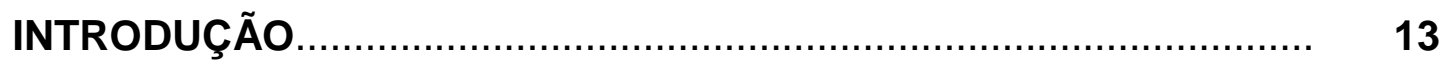

1 REVISÃo DA LITERATURA

2 METODOLOGIA

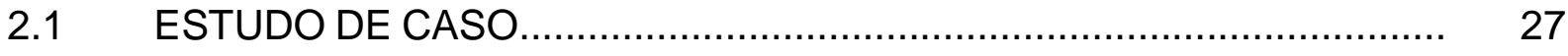

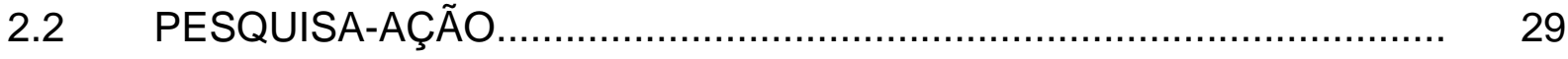

3 SETOR DE SERVIÇOS MÓVEIS DE VALOR AGREGADO (SMVA)... 33

3.1 O ECOSSISTEMA DE SMVA................................................... 33

3.2 O PAPEL DA INTEGRADORA NO MERCADO NACIONAL DE SMVA... 36

4 SETOR DE IMPLANTAÇÃO E O\&M DE EQUIPAMENTOS DE TELECOMUNICAÇÕES.......................................................... 40

4.1 DESCRIÇÃO DA EMPRESA ESTUDADA..................................... 40

4.2 PERFIL DE APRENDIZAGEM DOS COLABORADORES.................... 45

4.3 ANÁLISE E PLANEJAMENTOS DAS AÇÕES.................................... 47

4.4 PROVAS DE CONCEITO...................................................... 50

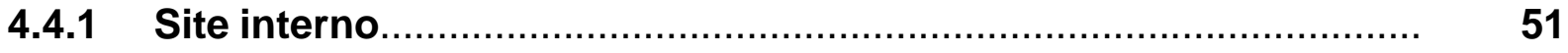

4.4.2 Cursos

4.4.2.1 Curso Integração..................................................................... 72

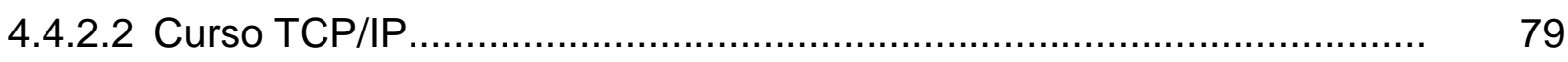

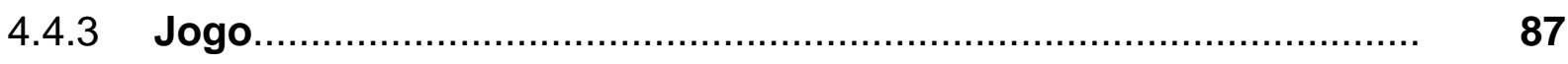

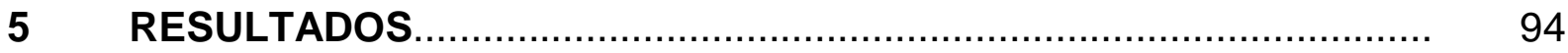

5.1 GESTÃO DO CONHECIMENTO NO SETOR DE SMVA....................... 94

5.2 DEMANDAS DE GESTÃO DO CONHECIMENTO DO SETOR DE IMPLANTAÇÃO E O\&M DE EQUIPAMENTOS DE TELECOMUNICAÇÃOES.................................................................. 97

6 DISCUSSÃO. 
APÊNDICE A - QUESTÕES SOBRE SMVA E A ESTRUTURA DO MERCADO BRASILEIRO DE TELECOMUNICAÇÕES (Integradora).. APÊNDICE B - QUESTÕES SOBRE SMVA E A ESTRUTURA DO MERCADO BRASILEIRO DE TELECOMUNICAÇÕES (ORMS).

APÊNDICE C - ROTEIRO DA ENTREVISTA SEMIESTRUTURADA REALIZADA NA EMPRESA DE IMPLANTAÇÃO E O\&M.

APÊNDICE D - FORMULÁRIO DE LEVANTAMENTO DE DADOS E INFORMAÇÕES - EMPRESA DE IMPLANTAÇÃO E O\&M.

APÊNDICE E - QUESTÕES SOBRE SERVIÇOS DE IMPLANTAÇÃO DE O\&M (ORMS)..

APÊNDICE F - QUESTÕES SOBRE SERVIÇOS DE IMPLANTAÇÃO DE O\&M (EMPRESA ESTUDADA).

APÊNDICE G - TERMO DE CONSENTIMENTO LIVRE E ESCLARECIDO (CEO E GERENTES DA INTEGRADORA)

APÊNDICE H - TERMO DE CONSENTIMENTO LIVRE E ESCLARECIDO (PRESIDENTE EMPRESA IMPLANTAÇÃO E O\&M) APÊNDICE I - QUADRO COM DADOS QUALITATIVOS DO ESTUDO REALIZADO COM AS ORMS.

APÊNDICE J - PESQUISA DE SATISFAÇÃO APLICADA NA EMPRESA DE IMPLANTAÇÃO E O\&M.

APÊNDICE K - QUADROS COM RESULTADOS QUALITATIVOS DA PESQUISA DE SATISFAÇÃO.

APÊNDICE L - AVALIAÇÃO DE REAÇÃO DOS CURSOS (PROVAS DE CONCEITO DA PESQUISA-AÇÃO).

APÊNDICE M - QUADROS COM RESULTADOS QUALITATIVOS DAS AVALIAÇÕES DE REAÇÃO DOS CURSOS

APÊNDICE N - DESCRIÇÃO DOS ELEMENTOS DA PROVA DE CONCEITO JOGO SÉRIO TCP/IP.

APÊNDICE O - AVALIAÇÃO DE REAÇÃO DA PROVA DE CONCEITO JOGO SÉRIO TCP/IP 


\section{INTRODUÇÃO}

O setor de telecomunicações tem apresentado crescimento significativo nas últimas décadas, redimensionando distâncias físicas e culturais por meio da ampliação do acesso à informação. Além de estabelecer novas formas de comunicação, a atuação desse mercado potencializa novos modelos de trabalho, aprendizagem, entretenimento, relacionamento, comércio, entre outros.

O mercado de telefonia móvel, por exemplo, conta com expansão a nível mundial, conectando pessoas e evoluindo de acordo com o dinamismo tecnológico. Há 3,4 bilhões de assinantes exclusivos no mundo, o que representa uma penetração de $47 \%$. Esta porcentagem aumenta para $79,3 \%$ na Europa; $70 \%$ na América do Norte; e 52,6\% na América Latina (GSMA Intelligence, 2014).

De acordo com GSMA e BCG (2013), a América Latina conta com 10\% do mercado global de telefonia móvel no que tange à receita, e com 164 milhões de assinantes de banda larga móvel. O mercado latino-americano encontra-se em fase de maturação, com desenvolvimento de novos serviços e aplicações e com a ampliação do acesso à banda larga móvel. $O$ acesso aos smartphones tem se expandido entre as classes média e baixa, graças à viabilização de planos com custos mais acessíveis (BIBOLINI; LANCASTER, 2014).

No Brasil, o número de assinantes/conexões de celulares, por exemplo, passou de 174 milhões, em 2009, para 280 milhões, em 2014, atingindo a densidade de 138 celulares para cada 100 habitantes. $O$ investimento total no setor, que representa 4,7\% do Produto Interno Bruto (PIB) do país, incluindo serviços fixos e móveis, foi de 31,7 bilhões em 2014, 12,7 bilhões a mais quando comparado com o investimento realizado em 2009. Em relação à banda larga móvel, nos primeiros nove meses de 2015, a porcentagem da população atendida chegou a 94,2\% (TELECO, 2014).

O setor de telecomunicações caracteriza-se, portanto, pelo dinamismo, com contínuo crescimento do número de usuários e de serviços e com constantes atualizações tecnológicas. Devido a esse crescimento, em 1997, foi criada a Lei Geral das Telecomunicações (LGT), no Brasil, autorizando a privatização do Sistema Telebrás e criando a Agência Nacional de Telecomunicações (Anatel).

Antes da privatização, os serviços de telecomunicações constituíam responsabilidade do Estado, por meio de suas empresas e institutos de pesquisa, que integravam o Sistema Telebrás (BATAGLIA; PINTO, 2004). Com a privatização, 
ocorrida em 1998, o monopólio público transformou-se em um sistema de concessão pública com operadoras de rede móvel (ORMs) privadas, que disputam a concorrência no mercado. As redes base passaram a operar vários serviços simultaneamente (voz, dados e imagens) e a fiscalização e outorga das radiofrequências foram assumidas pela Anatel (TATSCH, 2003).

O artigo 60 da LGT define o conceito de telecomunicação como "a transmissão, emissão ou recepção, por fio, radioeletricidade, meios ópticos ou qualquer outro processo eletromagnético, de símbolos, caracteres, sinais, escritos, imagens, sons ou informações de qualquer natureza" (BRASIL, 1997). De acordo com Telebrasil e Teleco (2014), o setor é dividido em três segmentos:

- serviços de telecomunicações: empresas que detêm a concessão ou autorização para prestação de serviços, como as ORMs e as operadoras móveis virtuais (OMVs);

- produtos e serviços para prestadoras de serviços de telecomunicações: fornecedores de equipamentos e suporte à prestação de serviços de telecomunicações;

- serviços de valor agregado: provedores de acesso à Internet, centrais de atendimento, entre outros serviços de valor adicionado, que envolvem empresas prestadoras de serviço que têm como suporte principal serviços de telecomunicações.

As ORMs representam o segmento com maior faturamento no mercado e que estabelece relação direta com o consumidor final. As empresas dos demais segmentos são responsáveis por fornecer equipamentos e serviços que preveem suporte operacional e produção de conteúdo/aplicações ao negócio das ORMs. Entre essas, destacam-se as integradoras e as empresas de implantação e operação e manutenção (O\&M) de equipamentos de telecomunicações.

A integradora faz parte do segmento de serviços móveis de valor agregado (SMVA) no Brasil, intermediando a relação entre provedores de conteúdo e ORMs. De acordo com Pure (2012), a integradora foi introduzida no mercado brasileiro para fornecer suporte e tecnologia para o uso da plataforma operacional, incluindo a telefonia como um canal de mídia. Sua função principal é fornecer serviços tecnológicos aos provedores de conteúdo para que possam expandir e monetizar seus produtos, além de dar suporte ao negócio das ORMs. 
As empresas de implantação e O\&M de equipamentos de telecomunicações, por sua vez, atuam no segmento de produtos e serviços para prestadoras de serviços, fornecendo suporte às redes das ORMs. Entre suas principais atividades, estão a execução de projetos de instalação e manutenção de equipamentos de telecomunicações, com destaque para a supervisão das torres de transmissão de dados e voz.

Ambas as empresas atuam no suporte de infraestrutura às ORMs e aos demais setores do mercado, garantindo a eficácia dos serviços de telecomunicações. A integradora não conta com concorrência agressiva no mercado, mas possui desafios importantes no atual ecossistema de produção de SMVA. Fries (2011) identificou a possibilidade de conexão direta entre provedores de conteúdo e ORMs como uma ameaça para sua atuação no atual ecossistema. Para o autor, as integradoras poderiam reverter esta ameaça, investindo na melhoria das ferramentas de análise, na qualificação profissional e em serviços diferenciais, com geração de relatórios e análises mais eficientes.

As empresas que atuam na implantação e O\&M de equipamentos de telecomunicações também contam com desafios significativos, como as constantes alterações tecnológicas; a expansão significativa do quadro de colaboradores, de acordo com a ampliação do acesso aos serviços; a dispersão geográfica das equipes; e a resolução de ocorrências de modo cada vez mais instantâneo, considerando que esse é um diferencial nos processos de licitação.

Como é possível observar, os segmentos representados por estas empresas contam com desafios distintos, mas cuja superação demanda, entre outras ações, um processo eficaz de gestão do conhecimento (GC). As integradoras precisam oferecer mais do que uma plataforma tecnológica de integração para sobreviverem no mercado e as empresas da área de serviços para prestadoras de serviços necessitam capacitar novos colaboradores de acordo com a atualização tecnológica, integrá-los em uma mesma rede de comunicação e garantir um banco de dados que otimize o tempo de resolução de ocorrências, cumprindo prazos cada vez mais reduzidos.

De acordo com Castells (2007), que define o conceito de Sociedade da Informação, no novo modo informacional de desenvolvimento, a fonte de produtividade encontra-se na tecnologia de geração de conhecimentos, de processamento da informação e de comunicação de símbolos. Para o autor, a 
informação é a matéria-prima desta nova sociedade e as tecnologias são desenvolvidas para agir sobre a informação.

Desse modo, a tecnologia, por si só, não é a única responsável por agregar valor às empresas que dão suporte aos serviços de telecomunicações e à sociedade, pois o foco está na informação e na geração de conhecimentos, a partir dos dados e informações produzidos e/ou viabilizados por essas tecnologias. É necessário, portanto, analisar a necessidade de organizar/processar informações para a elaboração de conhecimento estratégico e, então, verificar os recursos humanos e tecnológicos adequados à otimização deste processo.

A GC é, portanto, fator-chave para a geração de valor na sociedade da informação, na medida em que promove o registro de rotinas de trabalho, o compartilhamento de experiências entre equipes e viabiliza o acesso e o resgate do conhecimento gerado pela empresa. O conhecimento organizacional é, portanto, a soma do que sabem todos em uma organização e que lhe proporciona uma vantagem competitiva no mercado e em relação ao seu futuro (CHIAVENATO, 2010).

Um dos caminhos para a GC envolve a educação corporativa (EC), que visa ao desenvolvimento do capital humano para um melhor aproveitamento dos ativos de conhecimento e para a promoção da inteligência competitiva (IC). De acordo com pesquisa realizada pela Confederação Nacional da Indústria (CNI, 2011), com 1.761 empresas brasileiras, $41 \%$ afirmaram que a má-formação profissional prejudica o setor. Além da falta de mão de obra qualificada, a baixa qualidade da educação básica resulta em dificuldades para as organizações na hora de capacitar seus profissionais (RICHARD, 2013).

Observa-se, portanto, a necessidade de qualificar a mão de obra e de nivelar o conhecimento dos colaboradores para que estejam aptos a exercer o trabalho e a compartilhar experiências. Muitas vezes, porém, as empresas associam a EC à contratação de empresas de treinamentos, desconsiderando a necessidade de promoção da aprendizagem contínua, a identificação das demandas de informação e as contribuições dos colaboradores no planejamento das ações de capacitação e atualização.

No processo de GC, a participação dos colaboradores é essencial, uma vez que detêm as informações do dia a dia de trabalho e que são capazes de fazer análises críticas, elaborando conhecimento a partir de suas experiências. Assim, as tecnologias devem ser utilizadas de forma a atender às demandas do fluxo de 
informação, de modo adequado às necessidades particulares de determinada organização.

Diante deste cenário, verifica-se a oportunidade de estudar o setor de infraestrutura de telecomunicações, analisando o processo de GC e o uso das tecnologias de acordo com suas necessidades de informação e de geração de conhecimento estratégico. Para realizar esta análise e, então, estruturar um modelo de GC, propõe-se dois estudos. O primeiro é um estudo de caso realizado na maior integradora do Brasil, com o objetivo de analisar como a empresa, que intermedia o setor de SMVA, desenvolve GC e agrega valor a seus serviços, garantindo, assim, a fatia de $90 \%$ do mercado.

O segundo estudo, por sua vez, trata-se de uma abordagem mais ampla, uma pesquisa-ação desenvolvida na principal empresa do país na área de implantação e O\&M de equipamentos de telecomunicações. Presente no mercado desde a década de 70 , essa conta com sede física em mais de 10 estados nacionais e tem apresentado rápido crescimento nos últimos anos. O objetivo deste estudo é conhecer a realidade da empresa e suas demandas de informação, planejar e implementar ações, analisar os resultados e estruturar uma solução para GC, integrando tecnologias e recursos necessários à sua promoção, assim como as estratégias eficazes identificadas no primeiro estudo.

Para complementar a análise, propõe-se a aplicação de um questionário, com questões qualitativas e quantitativas, a representantes das ORMs, envolvidos na relação comercial com as empresas de infraestrutura de telecomunicações. A coleta dessas informações visa a possibilitar uma análise mais ampla do tema pesquisado, considerando não apenas o ponto de vista e o contexto das empresas estudadas, mas, também, a percepção de seus principais clientes.

Desse modo, entre os objetivos gerais da pesquisa, destacam-se:

- analisar o processo de GC no mercado de SMVA, identificando diretrizes para a geração de valor a partir do conhecimento, em um contexto dinâmico;

- analisar o contexto e as demandas de uma empresa que atua na implantação e O\&M de equipamentos de telecomunicações, planejando e implementando ações que permitam testar a receptividade dos gestores e dos demais colaboradores a uma proposta inicial de GC;

- estruturar um modelo de GC, integrando os resultados de ambos os estudos e o referencial teórico e prevendo o uso das tecnologias disponíveis em prol 
de um processo que atenda às demandas do setor de infraestrutura de telecomunicações.

Com foco nos objetivos gerais, são propostos os seguintes objetivos específicos:

- identificar os principais segmentos envolvidos, os principais desafios e a dinâmica relacionada à produção de conteúdo no setor de SMVA;

- compreender o processo de GC desenvolvido pela integradora, que intermedia a cadeia produtiva de SMVA, conectando provedores de conteúdo e ORMs;

- analisar o setor de implantação e O\&M de equipamentos de telecomunicações, que fornece suporte às ORMs, compreendendo sua atuação no mercado, seu modelo de negócio e gestão, suas ferramentas de comunicação e seu processo de EC;

- conhecer as ações desenvolvidas, as expectativas e os principais desafios do setor de infraestrutura de telecomunicações, no que tange à GC;

- estruturar uma proposta inicial de GC, implementando e testando ações, por meio de provas de conceito, em grupos de controle;

- sintetizar um modelo de GC contextualizado ao setor de infraestrutura de telecomunicações e que possa ser replicado e alterado por organizações com desafios e características semelhantes. 


\section{REVISÃO DA LITERATURA}

Para a fundamentação teórica da pesquisa, foi desenvolvido um levantamento bibliográfico transdisciplinar. Considerando a conceituação de Nicolescu (1999), ao contrário da pluridisciplinaridade, que ultrapassa as disciplinas, mas mantém seu fim inscrito na estrutura da pesquisa disciplinar; e da interdisciplinaridade, que diz respeito à transferência de métodos de uma disciplina para outra; a transdisciplinaridade se refere àquilo que está ao mesmo tempo entre as disciplinas, através das diferentes disciplinas e além de qualquer disciplina. O desenvolvimento de um estudo transdisciplinar justifica-se pela abrangência da GC, que envolve recursos humanos, comunicação, TI, metodologias de EC, modelos de gestão, entre outros. Desse modo, este estudo bibliográfico relaciona três áreas principais: GC, comunicação interna e EC.

Para iniciar a abordagem sobre a GC, é importante definir os conceitos de dados, informação e conhecimento. De acordo com Ferreira (2004), dados são valores, medidas, fragmentos de realidade, afirmações desestruturadas, que não autorizam conclusões lógicas. Dados, portanto, são matérias-primas que, quando estruturadas, tornam-se informação. Informação é factual, consiste em números, estatísticas ou outros conjuntos de dados que interessam a pessoas e empresas (KAHANER, 1996). Conhecimento, por sua vez, significa informação estruturada e capaz de gerar e agregar valor.

De acordo com Takeuchi e Nonaka (2008), o conhecimento é formado por dois componentes dicotômicos e aparentemente opostos: conhecimento explícito e tácito. O conhecimento explícito é expresso em palavras, números ou sons, podendo ser compartilhado na forma de dados, fórmulas científicas, recursos visuais, fitas de áudios, especificações de produtos ou manuais (TAKEUCHI; NONAKA, 2008), capturado por sistemas de Tl e formalizado como propriedade intelectual (ERICKSON; ROTHBERG, 2009). De acordo com Pimenta (2007), esse tipo de conhecimento, em particular, é a base da padronização dos processos em uma empresa.

O conhecimento tácito, por sua vez, inclui o conhecimento pessoal, incorporado à experiência individual, envolvendo fatores intangíveis como crenças pessoais, perspectivas e sistemas de valor (PIMENTA, 2007). De acordo com Takeuchi e Nonaka (2008), esse está enraizado nas ações e nas experiências do indivíduo, como ideias, valores ou emoções que incorpora, contando com dimensões técnica e 
cognitiva. A dimensão técnica corresponde às habilidades informais e de difícil detecção, muitas vezes, captadas no termo "know-how" que se refere a competência ou ao "saber como". A dimensão cognitiva consiste em crenças, percepções, ideais, valores, emoções e modelos mentais tão inseridos em nós que os consideramos naturais.

A criação do conhecimento organizacional é um processo que amplifica 0 conhecimento criado pelos indivíduos e o cristaliza no nível do grupo através do diálogo, discussão, compartilhamento de experiência, atribuição de sentido ou comunidade de prática (TAKEUCHI; NONAKA, 2008). Os autores identificaram quatro modos de conversão do conhecimento, que compõem o modelo SECl: socialização (tácito para tácito), externalização (tácito para explícito), combinação (explícito para explícito), e internalização (explícito para tácito). De acordo com Oliveira (2001), os modos de conversão devem ser integrados como etapas de um processo contínuo, que ocorre em um grupo, coletividade ou comunidade de praticantes na organização. Como consequência, este autor destaca que o processo de desenvolvimento do conhecimento e de desenvolvimento da comunicação de praticantes é basicamente interdependente.

Assim, conhecimento não se reduz à informação. Conhecer implica trabalhar com informações, com classificação, análise e contextualização, e a arte de vincular conhecimento de maneira útil e pertinente denomina-se inteligência (PIMENTA, 2003). A IC consiste, portanto, em um programa sistemático de coleta e análise de informações sobre atividades da concorrência e tendências gerais do negócio para promover as metas da empresa (KAHANER, 1996). A atuação dos profissionais de inteligência deve focar em cinco estratégias: oportunidades de mercado, ameaças dos concorrentes, riscos competitivos, vulnerabilidades chave e pressupostos essenciais (FAHEY, 2007).

Silva (2009) complementa a afirmação de Kahaner e Pimenta, explicando que a GC se refere à busca pelo conhecimento útil com origem na experiência e na análise minuciosa sobre o mercado, os processos de busca pela expertise coletiva da organização e de sua distribuição para garantir maior retorno. Assim, "o novo conhecimento gerado permite que a organização desenvolva novas habilidades e capacidades, crie novos produtos e serviços, aperfeiçoe os antigos, e melhore seus processos organizacionais" (ALVARENGA NETO, 2008, p. 81). 
A GC preocupa-se em identificar o melhor aproveitamento de ativos de conhecimento da organização. O capital intelectual (Cl) tem foco nos ativos intangíveis, envolvendo capital humano (habilidades, treinamento, experiência), estrutural (sistemas de tecnologia da informação - TI, cultura corporativa) e relacional (conhecimento interno relativo a setores externos, como clientes e fornecedores). Segundo Chiavenato (2010), o capital humano das organizações passou a ser uma questão vital para o sucesso do negócio, o principal diferencial competitivo das organizações bem-sucedidas. Neste contexto, cada colaborador deve atuar como uma frente de onda na busca de novas soluções e prepará-lo continuamente para este novo papel tem sido a motivação de reinventar as organizações, orientando-as para a aprendizagem (PINTO, 2011).

De acordo com Fleury e Oliveira (2001), o conhecimento existente na empresa e que não pertence apenas a um indivíduo, mas a grupos de indivíduos, e que é tácito, pois está na cabeça das pessoas, é a base das competências essenciais da organização, desenvolvidas por meio de processos de aprendizagem e que constituem fonte de vantagem competitiva. Neste contexto, Oliveira (2001) destaca que a função central da empresa é administrar o conhecimento de forma a otimizar o desempenho organizacional:

\footnotetext{
Por um lado, é importante identificar como o conhecimento individual pode ser transformado em uma propriedade coletiva da empresa. Por outro, é central descobrir as formas pelas quais o conhecimento organizacional pode ser disseminado e aplicado por todos como uma ferramenta para o sucesso da empresa (OLIVEIRA, 2001, p. 132).
}

De acordo com Heinrichs e Lim (2003), somado à capacidade de conversão de informação em inteligência, o sustento da vantagem competitiva demanda a combinação de três pré-requisitos: equipe capacitada e qualificada, cultura corporativa, focada na aprendizagem e no uso de ferramentas tecnológicas de ponta para a GC efetiva. Os recursos tecnológicos devem ser empregados de acordo com as demandas e projetos para a geração de valor a partir do conhecimento tácito e coletivo, e não como a solução única para a promoção de efetiva GC.

De acordo com Valle (2013, p. 123), "a maior parte das informações está dormindo no banco de dados em uma planilha na gaveta de alguém" e a inteligência de negócios (business intelligence - $\mathrm{BI}$ ) deve estar baseada em uma visão estratégica dos negócios para ter suas potencialidades bem aproveitadas, gerando resultados positivos para as organizações. Desse modo, a GC deve integrar ações que envolvam 
todos os setores e pessoas da empresa em prol da consolidação de uma cultura corporativa voltada para a troca de experiências e para 0 uso inteligente das informações disponíveis, ou seja, do conhecimento elaborado organizacionalmente.

Desse modo, em estudos de GC, a cultura corporativa e o comportamento têm se tornado questões chaves para lidar especialmente com a transferência do conhecimento tácito (MARUTA, 2014). A cultura corporativa é o conjunto de hábitos e crenças, estabelecidos por normas, valores, atitudes e expectativas, compartilhado por todos os membros da organização, podendo ser um fator de sucesso ou de fracasso às mesmas (CHIAVENATO, 2010). A tarefa de promover o relacionamento com os públicos não se restringe, portanto, aos profissionais de comunicação da empresa, mas demanda a implementação de uma cultura de comunicação, que mobilize e capacite todos os colaboradores a desempenharem a função de comunicar (BUENO, 2009).

Neste contexto, a comunicação interna, que é o esforço para vender a empresa e seus produtos aos próprios colaboradores (FERREIRA, 2004), torna-se relevante para promover a cultura corporativa, a EC e a GC. O senso de pertencimento a uma instituição demanda o conhecimento de seus valores, missão e visão, além da participação ativa no compartilhamento de informações e do conhecimento coletivo.

Pimenta (2007) destaca que a divulgação dos elementos que compõem a cultura corporativa da empresa disponibiliza um conjunto de referências sobre sua conduta ética e a maneira como trabalha. Desse modo, conforme afirma Lima (2013, p. 26), o sucesso de um projeto organizacional passa pelo envolvimento dos empregados, sendo fundamental que todos se identifiquem com a causa e que as ações sejam centradas no conhecimento: "que gera a crença e faz com que as pessoas passem a acreditar, realmente, que estão compartilhando a responsabilidade pelas melhorias e benefícios".

Segundo Senge (2006), as organizações de sucesso serão aquelas que descobrirem como cultivar nas pessoas o comprometimento e a capacidade de aprender em todos os níveis da organização, desenvolvendo uma visão compartilhada. Para o autor, a aprendizagem tende a se tornar mais importante do que o controle e a sua regra básica é considerar que as pessoas aprendem o que precisam aprender. A produção do conhecimento é, portanto, seletiva de acordo com os interesses e expectativas do sujeito (FISCHER; AMORIM, 2010). 
Para Sabbag (2010), as competências individuais e coletivas devem resultar em ativos da organização e a EC deve atender aos propósitos de ser um diferencial competitivo e um fator de mudança cultural e organizacional. Neste contexto, "os Sistemas de Educação Corporativa (SECs) têm desempenhado um papel estratégico na construção da competitividade empresarial por meio do desenvolvimento das competências humanas de forma atrelada às competências empresariais" (EBOLI, 2010, p. 140).

No processo de capacitação/atualização profissional, deve-se considerar, portanto, o conceito de aprendizagem, que coloca o colaborador como ator principal do processo, e descartar métodos que se preocupam apenas com o produto final, uma vez que a eficiência no aprendizado será obtida não por "o que estudar", ou seja, pelo conteúdo, mas sim no "como" estudar, enfatizando tanto o procedimento como as estratégias (IGNÁCIO, 2007). Assim, dentro de uma organização, os profissionais devem ser motivados a participar e colaborar do processo de aprendizagem, utilizando os recursos e conteúdos disponíveis da melhor forma possível para resolver problemas do dia a dia e trocar experiências.

De acordo com Burnham et al. (2005), a criação e o compartilhamento do conhecimento perpassam pelo processo de aprendizagem através da conversão de conhecimento tácito em explícito. Os autores destacam ainda que não existe um modelo único de EC, pois cada empresa tem características e culturas diferenciadas.

Neste processo, o uso das tecnologias também pode a agregar, possibilitando novas formas de interação e modalidades de educação, como a educação a distância (EAD). No Brasil, 56,9\% das instituições desenvolvem EC e 75\% de seus cursos são online (ABED, 2014). O uso mais intensivo da Internet representa o início da quarta geração de EAD. A primeira geração foi marcada pelo ensino por correspondência; a segunda pelo uso de tecnologias como o rádio, a TV, a teleconferência e o videotape; e a terceira pelo o uso das redes de computadores, das videoconferências e do CDROM, com desenvolvimento de programas de computadores e softwares educacionais (MOREIRA, 2009).

De acordo Tori (2010, p.19), que propõe o conceito de educação sem distância, ao considerar que o termo EAD enfatiza o problema, e não a solução, uma vez que se pretende ensinar apesar da distância, na educação apoiada por tecnologias interativas, os conteúdos e ferramentas digitais assumem papel de destaque e oferecem novas formas de trabalho e de aprendizagem. 
Em aplicações educativas, as tecnologias da informação e comunicação (TIC) podem gerar condições para um aprendizado mais interativo, por meio de caminhos não lineares nos quais o estudante determina seu ritmo, sua velocidade, seus percursos (NUNES, 2008). O modelo de educação centrado no estudante propicia flexibilidade e aprendizagem just-in-time, conceito que faz uma analogia com a administração e se refere à necessidade de um gerenciamento flexível para se adaptar às demandas (DE LUCA, 2011). As tecnologias não são, portanto, passivas no processo de educação, pois um novo tipo de linguagem gera uma nova forma de pensar o mundo e de estruturar relações (NOVA; ALVES, 2002).

$\mathrm{Na}$ relação estabelecida pela aprendizagem interativa o estudante assume, portanto, o centro do processo educacional e, neste contexto, conforme Referenciais (2007), a interatividade entre professores, tutores e estudantes consolida-se um dos pilares para garantir a qualidade de um curso a distância, processo facilitado pelo avanço das TIC. Assim, quando adequadamente orientados, os alunos são capazes de gerenciar a resolução de tarefas e problemas, tornando-se protagonistas de seu processo de aprendizagem (GUISASOLA; FURIÓ; CEBERIO, 2006). Desse modo, sendo o aluno o centro do processo de aprendizado, no qual sua experiência e interesses são peças fundamentais, identificar e saber tirar proveito do conhecimento dos estilos de aprendizagem pode ser garantia de sucesso (MOZZAQUATRO; MEDINA, 2009).

De acordo com Nunes (2008, p. 2), "a educação a distância é voltada especialmente (mas não exclusivamente) para adultos que, em geral, já estão no mundo corporativo e dispõem de tempo suficiente para estudar, a fim de completar sua formação básica ou mesmo fazer um novo curso". A solução, porém, não se restringe à contratação de cursos prontos, mas envolve a compreensão das demandas particulares de determinada empresa, do perfil dos colaboradores e dos recursos educacionais mais adequados. De acordo com Alves (2008), constata-se, em alguns cursos online, a mera transposição das práticas presenciais para a web, sinalizando uma dificuldade em interagir com a lógica instaurada nesses espaços de aprendizagem.

De acordo com Rosen (2009), muitas empresas investem em projetos e tecnologias sem conseguirem o esperado, pois não têm uma visão clara, focada em objetivos e no melhor caminho para mensurar os objetivos de aprendizagem. Para a autora, o objetivo do treinamento deve ser a criação de uma força de trabalho mais 
flexível, capaz de encontrar informações, ao invés de simplesmente memorizar procedimentos. Desse modo, os colaboradores devem ter "as competências necessárias para um bom desempenho profissional, além de ter acesso às informações e às ferramentas necessárias para um bom desempenho individual e grupal que leve em conta um contexto global” (MORAES, 2001, p. 119). O perfil do colaborador burocrático, que se limita a executar suas funções, é substituído por um novo perfil, que envolve autonomia, espírito crítico, liderança e flexibilidade (DE LUCA, 2011).

Deve-se considerar, também, as características e demandas do mercado e da sociedade nos quais a organização está inserida. A formação profissional contemporânea não se restringe à aquisição de instruções para a execução de trabalhos operacionais estabelecidos, mas deve se basear em um processo de aprendizagem contínua. De acordo com Zhang e Li (2011), nós aprendemos através do espaço, aplicando ou desenvolvendo recursos de aprendizagem elaborados em um local em outro; e através do tempo, relembrando conhecimentos elaborados anteriormente em um contexto diferente e através de ideias e estratégias elaboradas em anos anteriores, propiciando uma estrutura para uma vida de aprendizagem.

Segundo a Unesco (2014, p. 21), no cenário ideal da aprendizagem contínua, o aluno uitiliza vários recursos tecnológicos de acordo com as oportunidades que surgem e com as características dos mesmos: "a mobilidade de um smartphone, por exemplo, ou a superioridade do teclado de um computador de mesa - para manter a continuidade da experiência de aprendizagem ao passar de um dispositivo ou ambiente ao outro".

A aprendizagem com tecnologias móveis, por exemplo, caracteriza-se por disponibilizar treinamento de forma individualizada, disponível a qualquer hora e em qualquer lugar, com ferramentas colaborativas que proporcionam ambientes flexíveis para a aprendizagem (TUCKER; WINCHESTER, 2011). Mozzaquatro e Medina (2009) definem a aprendizagem móvel como a fusão de diversas tecnologias de processamento e comunicação de dados, que permite maior interação a alunos e professores. Neste estudo, considera-se aprendizagem móvel aquela disponibilizada via computador de mão/portátil, smartphones, telefones celulares, e-books e tablets. Conforme Keegan (2005), a definição deve estar focada na mobilidade, considerando dispositivos que possam ser carregados em uma bolsa de mão ou, até mesmo, no bolso. 
As mídias móveis se destacam também por permitirem o acesso ubíquo, ou seja, onipresente - a qualquer hora e em qualquer lugar - a informações, redes sociais, ferramentas para aprendizagem e produtividade, entre outros; e por serem, cada vez mais, a primeira escolha para acesso à Internet (JOHNSON et al., 2014). De acordo com Traxler (2009), os dispositivos móveis criam não apenas novas formas de conhecimento e novos caminhos para acessá-lo, mas também novas formas de arte e desempenho, novas formas de comércio e atividade econômica. Desse modo, o autor destaca que a aprendizagem móvel não é sobre mobilidade ou aprendizagem, mas integra uma nova concepção móvel de sociedade.

Os dispositivos móveis, quando adequados aos objetivos de aprendizagem e ao perfil dos estudantes e das instituições, potencializam o papel central do aluno no processo de educação, ampliando as possibilidades de acesso à informação, os formatos dos recursos educacionais e os trajetos rumo à elaboração de conhecimento. Segundo Wang, Yu e Sun (2010), a aprendizagem móvel amplia a flexibilidade da aprendizagem, permitindo diversos modelos de estudo, individualizado, coordenado, baseado em discussões, entre outros. O compartilhamento de competências, conhecimento e habilidades via tecnologias móveis e avançadas torna a aprendizagem colaborativa e o processo de aquisição do conhecimento adaptável (YORDANOVA, 2007).

A partir deste estudo bibliográfico, verifica-se que a GC envolve a conexão de diferentes áreas do conhecimento e a possibilidade de uso de diversos recursos e tecnologias. Observa-se, portanto, a necessidade de se considerar as demandas e particularidades de determinada empresa ou setor, o público envolvido, a cultura corporativa e as tecnologias disponíveis para, então, estruturar um modelo de GC efetivo, com potencial para gerar conhecimento estratégico e otimizar o $\mathrm{Cl}$. 


\section{METODOLOGIA}

Para a realização da pesquisa, foram utilizados dois métodos, estudo de caso e pesquisa-ação, e técnicas qualitativas e quantitativas, considerando a importância de coletar dados estatísticas e, também, informações relacionadas à percepção, conhecimento e experiências dos profissionais envolvidos no estudo. Desse modo, conforme propõe Richardson (1999), os métodos qualitativos irão auxiliar a pesquisa quantitativa, melhorando a formulação do problema, o levantamento de hipóteses e a determinação da amostra. Já os métodos quantitativos irão contribuir para a delimitação do problema estudado e das informações coletadas na pesquisa qualitativa.

O estudo de caso foi realizado entre 2012 e 2013 na maior integradora do país, com o objetivo de analisar a GC no setor de SMVA. O desenvolvimento de um estudo de caso único justifica-se pela representatividade da empresa estudada, que possui homologação com todas as ORMs do país, sendo responsável por, aproximadamente, 90\% das integrações nacionais, além de contar com escritórios em outros países, como Itália e México. A pesquisa-ação, por sua vez, foi realizada, entre 2013 e 2016, na principal empresa brasileira de implantação e O\&M de equipamentos de telecomunicações, tendo como proposta verificar a necessidade de informação do setor, planejar e implementar ações, analisar os resultados e, então, estruturar um modelo de GC.

\subsection{ESTUDO DE CASO}

O estudo de caso permite uma investigação que preserva as características holísticas e significativas dos acontecimentos na vida real, tais como processos organizacionais e administrativos (YIN, 2005). A estratégia de pesquisa estudo de caso demanda avaliação qualitativa, pois seu objetivo é a investigação de uma unidade social que se analisa profunda e intensamente (MARTINS; THEÓPHILO, 2007). A escolha da integradora entre as partes interessadas do mercado deve-se à sua característica estratégica de intermediar o fluxo de troca de informação entre provedores de conteúdo e ORMs.

Desse modo, foram realizadas entrevistas semiestruturadas, que têm como objetivo principal compreender os significados que os entrevistados atribuem às 
questões e situações relativas ao tema de interesse (GODOY, 2006). Foram entrevistados o diretor executivo, o gerente comercial e o gerente de operações da integradora. O gerente comercial atua na abertura de novos negócios da empresa, conquistando novos parceiros e buscando soluções para os principais clientes, que são as ORMs. Este profissional também é responsável pelo projeto de expansão da empresa para outros países do continente americano. O gerente de operações é responsável pela equipe de suporte, que atende às solicitações internas e externas dos parceiros, pelos sistemas, plataformas e infraestrutura de banco de dados e de servidores, que mantêm os serviços em funcionamento.

A pauta utilizada como guia para as principais abordagens dos entrevistados contou com 12 questões-chave relacionadas ao mercado de SMVA (apêndice A), à atuação da integradora, à GC e à IC. Todas as entrevistas, realizadas de forma presencial e online, foram gravadas em áudio para registro e posterior transcrição, evitando-se a perda de informações importantes e dinamizando seu processo de coleta.

Para complementar e validar as informações coletadas com os gestores da empresa estudada, foi desenvolvido um questionário com questões qualitativas e quantitativas, aplicado a gerentes e consultores de quatro das principais ORMs que atuam no país. Mais de 20 profissionais foram contatados por meio de mensagens online, mas apenas quatro concordaram em participar da pesquisa. Os gerentes e consultores respondentes representam quatro das cinco principais ORMs do país. O questionário (apêndice B), que também contou com 12 questões, foi respondido por um gerente de planejamento de rede, um gerente de gestão de rede e controle, um consultor de marketing de SMVA e um gerente de marketing SMVA.

As análises dos dados e informações coletadas nas entrevistas e nos questionários foram feitas de acordo com a categorização de informações. Conforme propõe Duarte (2005), as categorias derivam da revisão de literatura e se consolidam na pauta das questões propostas. Com base nesta técnica, as informações convergentes foram estruturadas em tópicos descritivos relacionados aos principais temas abordados no estudo, que visa a clarificar o entendimento do papel da integradora no setor de SMVA. A partir desta categorização, uma análise interpretativa foi realizada. De acordo com Gil (1994), essa difere da análise de conteúdo, uma vez que o foco está no conteúdo das categorias, e não na frequência dos códigos. 


\subsection{PESQUISA-AÇÃO}

A pesquisa-ação é um tipo de investigação-ação, e, portanto, visa aprimorar a prática pela oscilação sistemática entre agir no campo da prática e investigar a respeito dela (TRIPP, 2005). De acordo o autor, nesta metodologia, planeja-se, implementa-se, descreve-se e avalia-se uma mudança para a melhora de sua prática, aprendendo mais no decorrer do processo, tanto a respeito da prática quanto da própria investigação. O pesquisador atua, portanto, como um facilitador ou consultor, que auxilia as partes interessadas na definição clara de seus problemas e as engaja no trabalho de encontrar soluções efetivas para esses (STRINGER, 2007).

A fim de estudar o setor de implantação e O\&M de equipamentos de telecomunicações, para conhecer as expectativas e os desafios relacionados à GC, foi realizada uma pesquisa-ação na maior empresa que atua nesta área no Brasil. $A$ motivação para a escolha desta empresa deve-se a uma série de fatores, como: tempo significativo de operação no mercado brasileiro de telecomunicações, permitindo-a vivenciar o período anterior e posterior à privatização do setor de telefonia; sua atuação na área de infraestrutura, apontada por Vieira (2013) como um dos desafios para a expansão do mercado nacional ao lado da burocracia e da alta carga tributária, uma vez que a legislação dificulta o processo de implantação de antenas; aumento expressivo do número de colaboradores; dispersão dos colaboradores em diversas localidades do país, o que representa um desafio para o desenvolvimento de ações de EC, comunicação interna e integração das equipes; relacionamento com outros setores do mercado, como as ORMs e os fornecedores de equipamentos; e disponibilidade de seu presidente e de seus gestores para a troca de informações e colaboração para o estudo.

A estrutura para a realização da pesquisa segue a proposta de Stringer (2007), que consiste em observar, pensar e agir. A primeira etapa está relacionada à coleta de informações relevantes e à descrição do contexto estudado. A fase "pensar" envolve a exploração, análise, interpretação e explicação dos fatos. O "agir", por sua vez, corresponde ao planejamento, implementação e avaliação da ação proposta. Desse modo, as atividades de desenvolvimento da pesquisa foram organizadas a partir destas três etapas. Na etapa de observação, foram utilizadas as seguintes técnicas: 
- entrevista semiestruturada (apêndice C), realizada com o presidente e o supervisor de treinamentos, a fim de compreender o contexto e a atuação da empresa, a partir de informações como principais serviços, clientes, concorrentes e fornecedores; modelo de negócio anterior e posterior à privatização do Sistema Telebrás; perfil profissional dos colaboradores; e ações de GC, comunicação e EC;

- aplicação de um formulário de levantamento de dados e informações (apêndice D), preenchido pela coordenadora de recursos humanos $(\mathrm{RH})$, pelo gerente técnico, pelo supervisor de treinamentos e pelo gerente de operações, com questões que visam à compreensão do perfil dos colaboradores, das ferramentas de comunicação, do formato de EC e dos perfis profissionais desejados;

- observação participante de um curso presencial da área técnica, ministrado para novos colaboradores, a partir da qual é possível identificar o formato dos conteúdos ministrados, os recursos didáticos, comunicacionais e tecnológicos utilizados e a receptividade/interação dos colaboradores;

- identificação do perfil dos colaboradores (escolaridade, área/tempo de atuação, cargo, entre outras), por meio do acesso a uma planilha de dados cadastrais, disponibilizada pela coordenadora de $\mathrm{RH}$;

- identificação dos principais estilos de aprendizagem dos colaboradores, por meio do uso da Ferramenta de Identificação do Perfil de Aprendizes (FIPA), desenvolvida por Bativa (2011), com base na teoria das inteligências múltiplas de Gardner (1995), com o propósito de auxiliar no processo de planejamento de ações de EC.

A etapa do "pensar" contou com análise dos dados e informações coletadas na primeira fase da pesquisa; estudo teórico sobre os temas relacionados às características e demandas da empresa estudada; e reuniões realizadas de forma presencial e online com o presidente da empresa e com a equipe responsável pelo departamento de treinamentos (supervisor de treinamentos, técnico de telecomunicações sênior e gerente técnico). As ferramentas de conversa online instantânea e o e-mail foram recursos utilizados massivamente para a comunicação com os colaboradores participantes da pesquisa. Nesta etapa, foram relacionados, 
juntamente com a empresa estudada, as principais demandas de informação e os principais desafios para a promoção da GC.

$\mathrm{Na}$ terceira etapa do projeto, o "agir", constam o planejamento, a implementação e a avaliação das provas de conceito desenvolvidas em trabalho conjunto com os gestores para testar recursos e linguagens e, então, permitir a estruturação de um modelo de GC adequado às necessidades identificadas na coleta de informações e validadas pelos colaboradores. O formato das provas de conceito, os grupos de controle e as estratégias para divulgar a proposta e promover o engajamento dos colaboradores, além da especificação dos dispositivos e softwares e dos recursos utilizados para avaliação das ações, também foram atividades realizadas nesta etapa. Entre os fatores considerados para o desenvolvimento e a implementação das ações, destacam-se o perfil dos colaboradores, as tecnologias disponibilizadas pela empresa, o modelo de negócio, a forma como a empresa se organiza e o uso de softwares gratuitos e abertos.

Para complementar a pesquisa e a elaboração do relatório final, que consolida os resultados das avaliações propostas e a análise do pesquisador em relação a todo o processo de pesquisa, foram desenvolvidos dois questionários (apêndices $E$ e F), com questões dissertativas sobre a relação comercial no setor de serviços de implantação e O\&M de equipamentos de telecomunicações. Esses questionários foram aplicados ao gerente comercial da empresa estudada e a representantes das ORMs, que atuam no relacionamento com empresas que prestam serviços na área de infraestrutura. Por meio da rede social de negócios, Linkedin, foram contatados 30 profissionais, com retorno e participação final de sete respondentes, para os quais não foi informada a identidade da empresa estudada.

Participaram da pesquisa profissionais de cinco das principais ORMs que atuam no país, com as seguintes áreas de atuação: O\&M de redes, engenharia de telecomunicações, planejamento e engenharia de redes, consultoria de núcleo de rede e engenharia de implementação de redes. A aplicação dos questionários visa à comparação da percepção da equipe comercial e de representantes das ORMs, principais clientes da empresa estudada, em relação aos serviços prestados, à equipe profissional e ao relacionamento comercial. Desse modo, o modelo proposto para a GC no setor de infraestrutura de telecomunicações prevê, também, as necessidades de informação identificadas pelos clientes. 
Os representantes das empresas estudadas no estudo de caso e na pesquisaação assinaram um termo de consentimento livre e esclarecido (apêndices $\mathrm{G}$ e $\mathrm{H}$ ), documento através do qual foram informados sobre os objetivos e a finalidade da coleta de informações, ambos restritos à elaboração deste estudo, e sobre a garantia de anonimato de sua identidade e da identidade da empresa. Os respondentes representantes das ORMs, por sua vez, assinalaram, no próprio questionário, a permissão para uso das informações neste estudo, também com garantia de anonimato. 


\section{SETOR DE SERVIÇOS MÓVEIS DE VALOR AGREGADO (SMVA)}

\subsection{O ECOSSISTEMA DE SMVA}

De acordo com Valle (2013), "um sistema de telecomunicações é um conjunto de hardware e software, utilizado para transferir informações, tais como texto, dados, gráficos, vídeo ou voz, entre dois locais". O serviço de voz foi, por um período relevante de tempo, o destaque no setor. Porém, com a 3G, as ORMs passaram a ter um canal de dados, ampliando a oferta de serviços de dados e de valor adicionado. De acordo com a Lei Geral das Telecomunicações, o serviço de valor adicionado é a atividade que acrescenta, a um serviço de telecomunicações que lhe dá suporte e com o qual não se confunde, novas utilidades relacionadas ao acesso, armazenamento, apresentação, movimentação ou recuperação de informações (BRASIL, 1997).

A receita de dados e de SMVA pode ser dividida em três componentes principais: serviço de mensagens curtas (SMS - short message service) e serviço de mensagem multimídia (MMS - multimedia messaging service); acesso à Internet (pacote de dados); e outros serviços de valor adicionado (serviços de mensagens, entretenimento, redes sociais, pagamentos, serviços de localização, entre outros) (TELECO, 2016). Nas principais ORMs $3 \mathrm{G}$ do mundo, a receita relacionada aos SMVA tem sido significativa para a receita líquida. No segundo trimestre de 2015, a porcentagem foi de 71,6\% na NTT DoCoMo (Japão); 70\% na Verizon (Estados Unidos); 51\% na Everything Everywhere (Europa); e 46,1\% na Vivo (Brasil).

Juntamente com as ORMs, os demais envolvidos neste mercado estruturam o setor de SMVA como um ecossistema, ou seja, conforme define Basole (2008), compõem um sistema de rede complexa na qual estabelecem relações interdependentes e simbióticas.

De acordo com GSMA et al. (2012), os segmentos desse ecossistema são: ORMs/over-the-top players (OTTPs), fabricantes de dispositivos móveis, fundações internacionais, desenvolvedores de conteúdo e sócios locais. Os OTTPs, como Skype, Netflix, Google, WhatsApp, PayPal e Facebook, criam novo valor para os serviços móveis. Esses vendem diretamente a seus clientes, usam sistemas de pagamento eletrônicos e faturam por serviços fornecidos (JAGANNATH, 2013). Na figura 1, é possível observar relações de interdependência entre os diferentes segmentos deste 
ecossistema, no desenvolvimento e disponibilização de diferentes produtos e serviços.

Figura 1 - Ecossistema padrão de SMVA

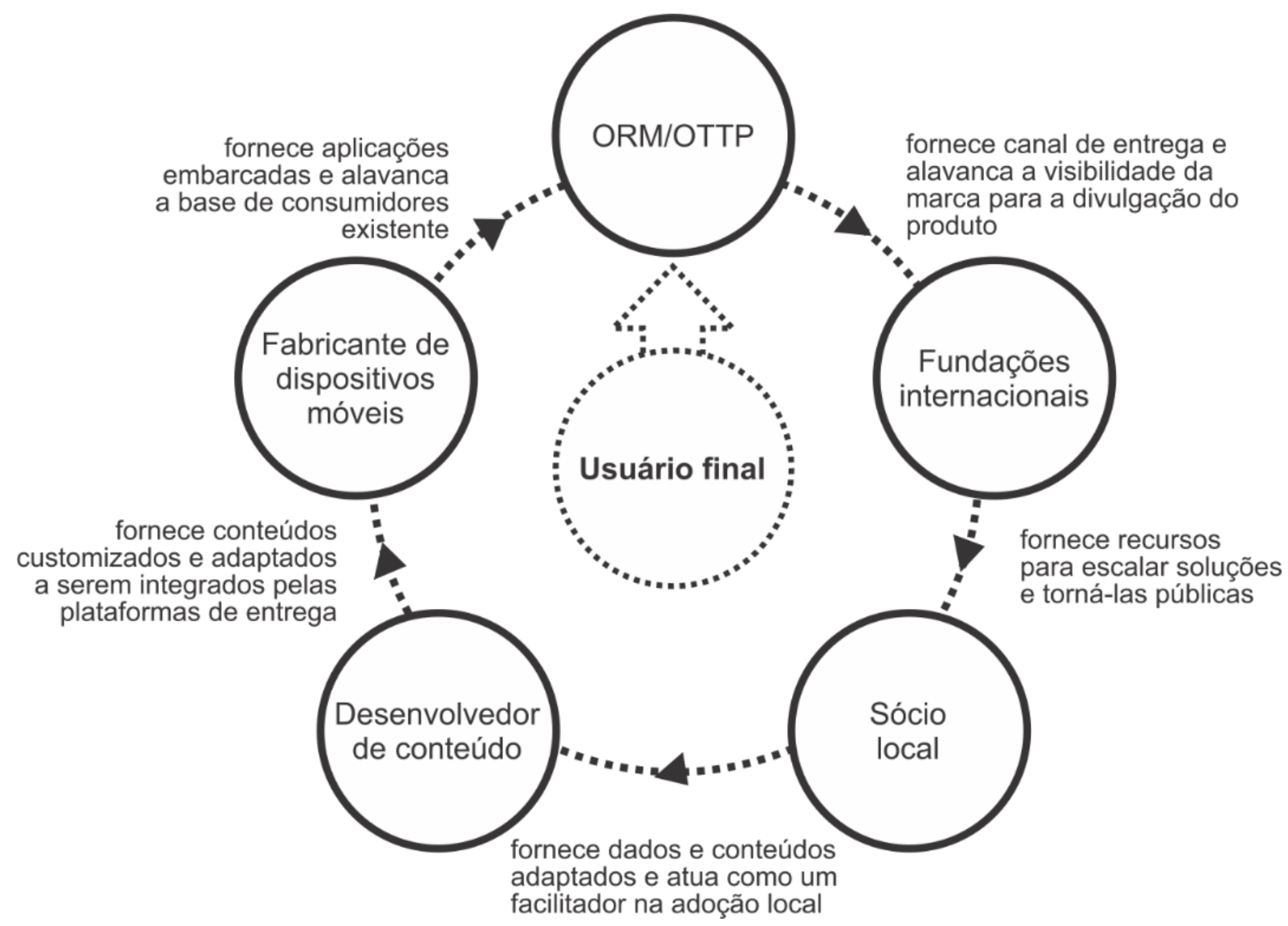

Fonte: GSMA mWomen et al. (2012).

No Brasil, por sua vez, os principais envolvidos no setor de SMVA são: ORMs, provedores de conteúdo e integradora. O serviço de integração é potencialmente multifacetado, incluindo modelos de negócio distintos, como configuração de portal móvel, agregação de conteúdo de várias fontes e customização de pacotes de serviços para diferentes segmentos do mercado (MYLONOPOULOS; SIDERIS, 2006).

Desse modo, conforme figura 2, no setor brasileiro de SMVA, provedores fornecem conteúdo a ser integrado pela integradora que, por sua vez, fornece tecnologia para disseminá-lo por meio das ORMs, alcançando os usuários finais. Outro fluxo alternativo ocorre quando os provedores apresentam projetos diretamente para as ORMs que, por sua vez, os enviam para a integradora. O setor é regulado pela Agência Nacional de Telecomunicações (Anatel), criada para promover o 
mercado brasileiro de telefonia móvel e que, em 2010, publicou leis relacionadas aos SMVA. Além da Anatel, há associações autorregulatórias, como o Mobile Entertainment Forum (MEF), associação global da indústria móvel que desenvolve códigos de conduta com procedimentos para serviços e publicidade móveis. As porcentagens indicadas na figura representam o faturamento aproximado de cada segmento deste mercado.

Figura 2 - Ecossistema brasileiro de SMVA

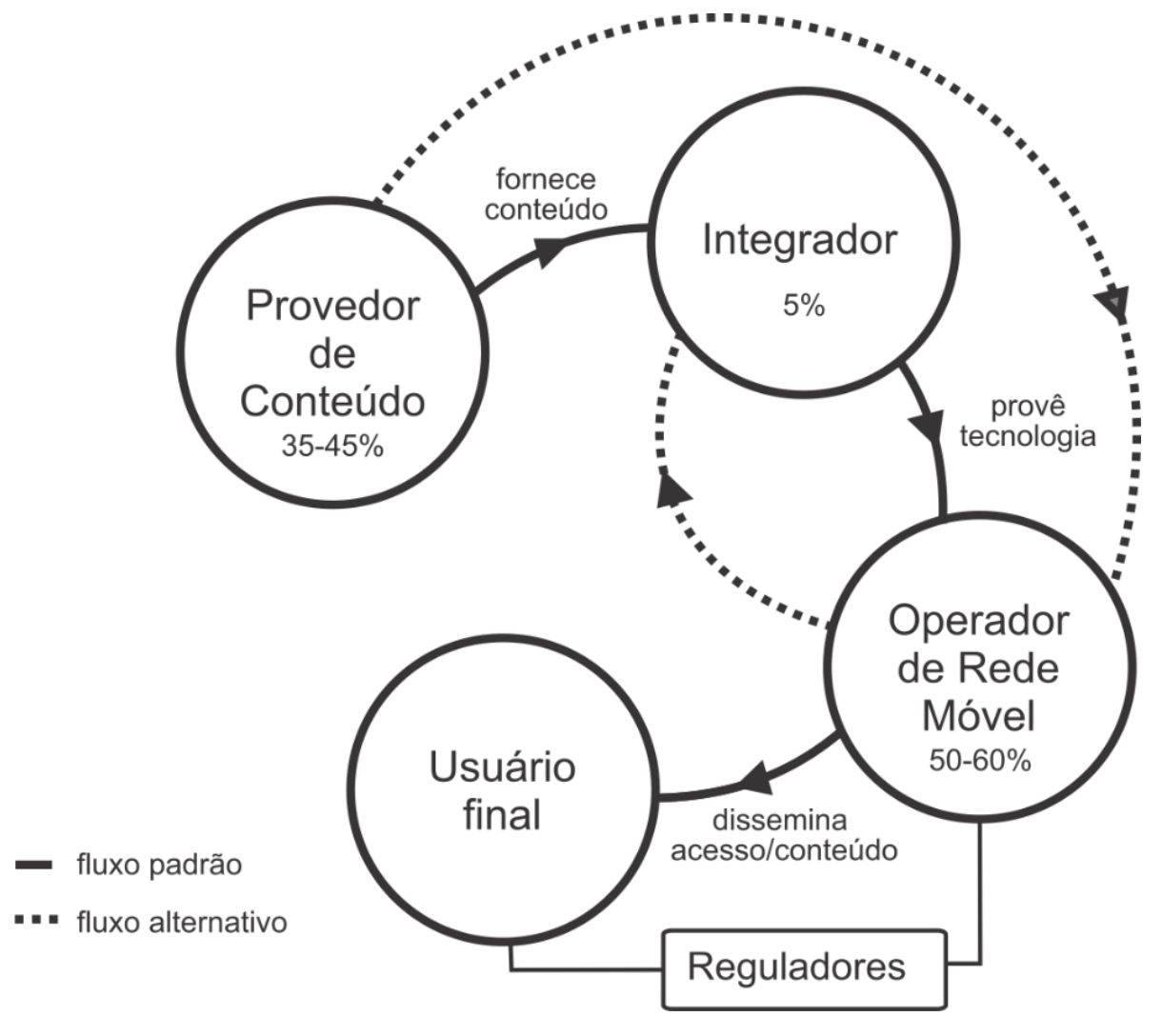

Fonte: Autora.

Os três segmentos do ecossistema brasileiro de SMVA atuam, portanto, em conjunto para criar um modelo de negócio lucrativo para todas as partes. Porém, a dinamicidade do mercado de telecomunicações, com a regulamentação recente, a convergência tecnológica e a expansão da venda de smartphones e tablets, por exemplo, tem promovido transformações de papéis neste setor. Silveira (2008) destaca que as ORMs têm sido o motor deste mercado, mas que os modelos de negócio têm passado por mudanças devido à entrada de novos atores, diretamente relacionados à convergência tecnológica. De acordo com Jenkins (2008, p. 40), "os 
velhos meios de comunicação não estão sendo substituídos. Mais propriamente, suas funções e status estão sendo transformados pela introdução de novas tecnologias".

Entre 2008 e 2015, o número de celulares 3G no país passou de 1.692 para 149.119 (TELECO, 2016). Com a ampliação do acesso à Internet móvel, surgem as lojas de aplicativos e expandem-se as possibilidades de produção e distribuição de conteúdo a empresas como Google e Apple, que apresentam autonomia em relação às ORMs.

Em relação aos usuários finais, há a priorização da utilidade da comunicação móvel e dos serviços de informação, assim como da usabilidade e da acessibilidade. Desse modo, os serviços devem ser desenvolvidos com os usuários finais, e não para os usuários finais, atentando-se para suas necessidades e preferências (NIKOU; MEZEI, 2013). Neste sentido, as novas tecnologias da computação e comunicação e o estabelecimento de sistemas de comércio global razoavelmente abertos fornecem mais escolhas aos consumidores, fazendo com que os negócios precisem ser mais centrados no consumidor (TEECE, 2010).

Inserido neste contexto de transformações tecnológicas e de modelos de negócios, o próximo item analisa o mercado de telefonia móvel brasileiro, focando no papel do integrador, que atua fornecendo infraestrutura para o ecossistema SMVA, e em suas ações para intermediá-lo diante dos desafios atuais. O estudo realizado na maior integradora brasileira analisa a GC e as soluções encontradas para garantir espaço e vantagem competitiva neste mercado.

\subsection{O PAPEL DA INTEGRADORA NO MERCADO NACIONAL DE SMVA}

Com base nas entrevistas realizadas com os gestores da integradora estudada, assim como nas informações coletadas de gerentes e consultores de quatro relevantes ORMs, é possível analisar o processo de intermediação do ecossistema de SMVA e as estratégias para atuação em um mercado dinâmico como o de telecomunicações.

Quando questionados sobre as principais diferenças observadas entre 0 mercado internacional e nacional de telefonia móvel, os representantes das ORMs destacam que o papel da integradora é mais comum na América Latina, enquanto em países como Espanha e Portugal, empresas com foco em integração são raras. Nestes países, são mais comuns empresas que operam com desenvolvimento e 
agregação de conteúdo juntamente com integração. Desse modo, a integradora representa um segmento diferencial do mercado latino-americano.

A integradora estudada define-se como uma empresa de faturamento do mercado de SMVA, cuja atividade principal é tarifar o usuário que deseja comprar serviços de provedores de conteúdo. Essa atua com modelos de assinatura ou downloads, interatividade, marketing móvel e protocolos de aplicações sem fio (WAP - Wireless Application Protocol).

Seus principais serviços são: votação via SMS, teletexto, pincode (promoções com código impresso em embalagens), quizz, transmissão, jogos, vídeos, canais de conteúdo e gestão de campanhas de marketing móvel. Há, ainda, o desenvolvimento de tecnologias que permitem transações de envio de SMS em programas de televisão, configuração de dispositivos móveis para receber atualizações de redes sociais, entre outras.

A empresa opera com contratos de compartilhamento de receitas e no modelo "empresa a empresa", conhecido pela sigla B2B (business-to-business), integrando conteúdos para comercialização pelas ORMs, sem participar da comunicação com os consumidores finais e sem representar concorrência aos demais segmentos do mercado.

Para compreender melhor o papel da integradora, as informações coletadas junto a seus gestores foram estruturadas em quatro categorias: $\mathrm{Cl}$, monitoramento ambiental, BI e IC (ver apêndice I). Em relação ao Cl, verifica-se um balanceamento, com foco nas três formas de Cl: capital humano, estrutural e relacional. Neste sentido, o gerente comercial destaca que não basta desenvolver as melhores tecnologias, sem contar com uma boa estrutura operacional e com um bom relacionamento com os clientes.

O CEO também ressalta a importância da equipe de gestão para o negócio da empresa e destaca que as empresas do futuro serão aquelas que valorizarem o capital humano. A empresa conta com profissionais da área técnica, com perfil mais moderado, conservador, factual e analítico; e da área comercial, com perfil mais agressivo e proativo.

O capital estrutural da empresa constitui-se de plataformas de integrações e de $\mathrm{Bl}$, que realizam a integração e geram registros sobre as transações diárias. A equipe técnica é responsável por desenvolver grande parte das tecnologias da empresa, o que garante a adequação dessas ao seu negócio. 
O capital relacional, por sua vez, é estratégico devido à atuação da integradora como segmento intermediário do mercado de SMVA. O gerente de operações destaca que a empresa é uma integradora pura, com foco somente no faturamento, não desenvolvendo serviços que não se enquadram ao seu escopo de atuação. O gerente comercial conclui que a empresa criou um padrão de mercado e atuou na regulamentação do mesmo, como um braço das ORMs, em uma relação de parceria.

De acordo com os gestores, a integradora tem operado, atribuindo maior ênfase ao capital humano e relacional, do que ao capital estrutural. As análises estratégicas, desenvolvidas por seus colaboradores, a partir dos dados coletados por meio das ferramentas de $\mathrm{Bl}$, e o bom relacionamento com as ORMs e com os provedores de conteúdo têm se mostrado relevantes para seu desempenho positivo no mercado de telecomunicações.

A integradora tem investido, ainda, na consolidação de uma equipe de TI mais proativa, promovendo melhorias na comunicação interna e externa. A empresa tem desenvolvido EC relacionada tanto à plataforma de integração, quanto à dinâmica do mercado de SMVA. Esses investimentos revelam a importância do bom relacionamento com empresas parceiras, juntamente com o desenvolvimento de uma equipe qualificada e de uma robusta base tecnológica.

No que se refere ao monitoramento ambiental, o foco da empresa está nos registros internos, e não na concorrência, que tem seus movimentos observados a partir de um modelo de visão não direcionada, que, de acordo com Choo (1999), objetiva detectar sinais precoces de mudanças, sem focar em informações específicas. O objetivo, portanto, é superar desafios próprios, com melhorias na gestão, a partir das análises das reclamações dos parceiros.

O gerente comercial destaca, ainda, a realização de pesquisas formais e informais para a promoção de melhorias nos serviços. São realizadas, por exemplo, pesquisas sobre a atuação de empresas estrangeiras, que tenham soluções que possam agregar valor aos serviços da integradora. O objetivo é observar, também, demandas para serviços como os de utilidade pública e pagamento móvel.

Em relação às ferramentas de $\mathrm{BI}$, a integradora conta com uma base de dados única, que auxilia no armazenamento de dados e no monitoramento ambiental, com geração de relatórios customizados. De acordo com o gerente de operações, as análises realizadas pela plataforma são básicas, com levantamentos de dados simples, como a comparação do número de usuários pós-pago e pré-pago que 
contratam determinado serviço. A integradora consegue observar também se o provedor conseguirá tarifar um usuário dez vezes ou uma só vez, o que auxilia as empresas parceiras no planejamento de ações estratégicas.

A plataforma de integração gera entre 20 a 30 milhões de registros por dia, o que demanda análises mais elaboradas para transformá-los em informações estratégicas. Essas análises, que consolidam a IC da empresa, são realizadas pela área de garantia de receita, que faz o monitoramento contínuo dos serviços, cliente a cliente, gerando relatórios comparativos de um determinado dia em relação aos dias anteriores. Esta área participa dos processos de tomada de decisão da organização, consolidando-se como um setor de planejamento que atua junto aos parceiros, buscando melhorias em seus resultados e desenvolvendo relatórios mensais com informações fundamentais à vantagem competitiva da empresa e de todos os segmentos do mercado de SMVA.

Com base nas análises realizadas, a integradora cria índices de comportamento de mercado. Desse modo, ao serem identificados desvios de padrão no tráfego de um provedor, por exemplo, esse é sinalizado imediatamente. Neste caso, devido à urgência da informação para a empresa parceira, a empresa não aguarda a geração de relatórios formais, enviados aos provedores no final de cada mês, para notificar o desvio. Além das análises estratégicas, a integradora também realiza consultorias, a fim de orientar sobre a viabilidade de projetos no mercado de SMVA.

Observa-se que a empresa desenvolve pesquisas sobre tendências de mercado e observa suas movimentações atentamente, identificando o comportamento dos usuários finais, conhecendo os melhores dias para consumo de bens virtuais no celular e os períodos nos quais os consumidores têm crédito, entre outras. Desse modo, além da integração, fornece valor agregado por meio de GC, gerando informações estratégicas, qualificando seus profissionais e estabelecendo um relacionamento de parceria com seus clientes. 


\section{SETOR DE IMPLANTAÇÃO E O\&M DE EQUIPAMENTOS DE TELECOMUNICAÇÕES}

\subsection{DESCRIÇÃO DA EMPRESA ESTUDADA}

A empresa estudada na pesquisa-ação atua, há mais de 30 anos, no setor de serviços para prestadoras de serviços de telecomunicações, na implantação e O\&M de redes; na instalação, realização de testes e comissionamento de equipamentos de telecomunicação; e na construção de estações rádio base e adaptação de infraestrutura.

De acordo com o presidente da empresa, o mercado nacional de telecomunicações conta com duas fases principais: antes e após a privatização do Sistema Telebrás, que era cliente único por meio das estaduais Telesp, Telemig, entre outras. Ele explica que a privatização promoveu mudanças tecnológica e institucional. Antes da privatização, os procedimentos de implantação e O\&M da infraestrutura de telecomunicações era replicado em todo o país. Não havia diversidade tecnológica, os padrões eram bem definidos, um trabalho durava meses e o conhecimento técnico aprendido era aplicável por até mais de quatro anos.

A atualização, em um curto intervalo de tempo, das redes $2 \mathrm{G}, 3 \mathrm{G}, 4 \mathrm{G}$ e, agora, $5 G$ tem alterado a dinâmica do mercado de telecomunicações, criando a necessidade de atualização constante de conhecimento técnico. Em relação à mudança institucional, as ORMs privatizadas apresentam concorrência significativa entre si, transferindo-a para a empresa de implantação e O\&M, com pressão para a redução de preço e de prazos na resolução de ocorrências.

A empresa estudada possui um centro de controle que, ao identificar ocorrências nas estações dos clientes, aciona o técnico mais próximo para solucionar o evento. As ocorrências não se resumem a defeitos técnicos, que representam menos de $20 \%$ do total, mas englobam também vandalismo, falta de energia, desastres ambientais, entre outros. Em relação aos prazos para resolução, há três tipos de criticidade: falha minoritária (até 12h); falha majoritária (até 6h) e falha crítica (até 3h - interrupção total do serviço em um determinado site/estação telefônica).

Com as transformações do mercado, aumentam-se os desafios da empresa, assim como a sua área de atuação. Em 2013, a empresa contava com 780 colaboradores, número que cresceu para 1962 em 2016. Em relação à abrangência, 
passou-se de 10 para 12 estados nacionais, no mesmo intervalo de tempo. Observe no gráfico 1, o percentual de colaboradores por regiões de atuação da empresa. A sigla NE representa todos os estados da região Nordeste nos quais a empresa atua.

Gráfico 1 - Regiões de atuação da empresa de implantação e O\&M

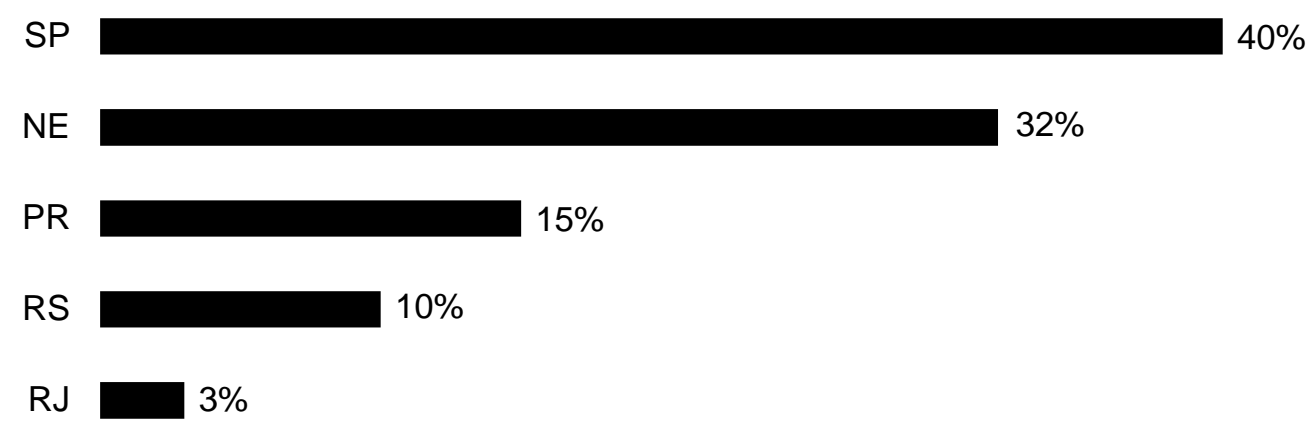

Fonte: Autora.

Somado a essas mudanças, encontra-se o desafio da qualidade profissional, com destaque para a mudança de postura dos recém-formados que, de acordo com o presidente da empresa, estão menos qualificados, não têm o mesmo interesse no aprendizado de novos procedimentos e tecnologias, assim como em seguir carreira técnica. Para colaborar com a preparação dos profissionais que atuarão na área de telecomunicações, a empresa tem investido em parcerias com escolas técnicas, ministrando palestras sobre o mercado e apresentando os equipamentos que são utilizados no setor de infraestrutura de telecomunicações.

A empresa conta também com um departamento de treinamento, com três profissionais, responsável pela formação de colaboradores e de multiplicadores. Os novos colaboradores, em sua maioria, realizam treinamentos práticos, com duração superior a um mês, sobre os equipamentos que serão utilizados no dia a dia de trabalho em campo.

A capacitação é feita, principalmente, para os colaboradores que atuam na área técnica, que representam $90 \%$ do total. Os setores administrativos e gerencial contam com poucas ações de EC, destacando-se a integração e um curso sobre normas de segurança do trabalho. De acordo com os gestores, não há avaliação adequada da eficácia dos treinamentos, ou seja, não há indicadores que validem/direcionem as ações de capacitação e atualização profissional. Devido ao crescimento expressivo do número de colaboradores e da dispersão dos mesmos em diversas localidades do país, a empresa encontra cada vez mais dificuldades para ministrar os treinamentos. 
Vale destacar que $82 \%$ trabalham exclusivamente em campo, enquanto somente $18 \%$ trabalham em escritórios.

Desse modo, os gestores consideram ações de EAD adequadas à atividade da empresa e ao perfil jovem de seus colaboradores (ver gráfico 2). Nos últimos anos, o departamento de treinamento tem testado o Ambiente Virtual de Aprendizagem (AVA) Moodle, com a aplicação de um questionário conceitual online, a fim de verificar o conhecimento técnico dos colaboradores e, então, desenvolver ações para padronizálo e aprimorá-lo. Em relação ao perfil comportamental e gerencial, ainda não foram promovidas ações de treinamento na plataforma.

Gráfico 2 - Faixa etária dos colaboradores da empresa de implantação e O\&M

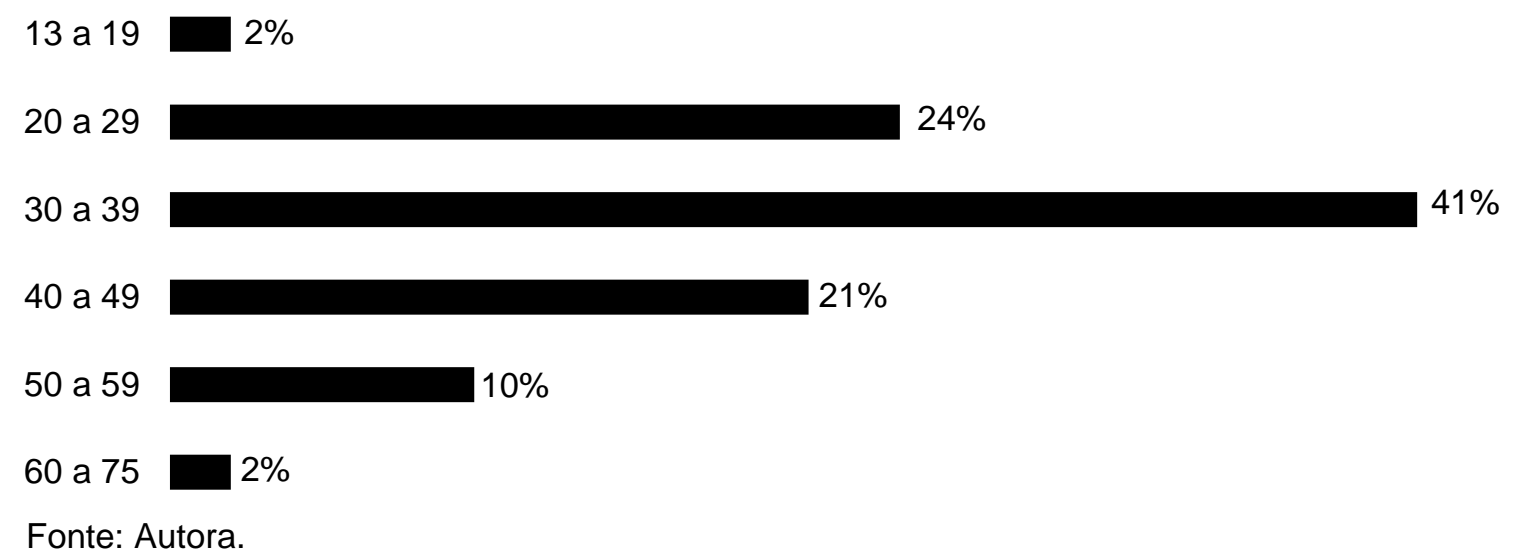

Entre as expectativas da empresa para aprimorar a EC, estão: o desenvolvimento de jogos educativos, que atendam às características da nova geração de colaboradores; a capacitação daqueles interessados em atuar como multiplicadores e tutores; a motivação para o registro de resoluções de problemas desenvolvidas nas diversas localidades em que atua; a priorização da experiência do usuário na elaboração dos treinamentos corporativos, a fim de que se tornem mais atrativos; a formação de organizadores de informação, e não só de consumidores; e a criação de um programa de certificação com o selo da empresa.

Em relação aos perfis desejados, os respondentes comentam a partir de deficiências identificadas nos três setores de atuação: técnico, gerencial e administrativo. Em relação ao setor técnico, além do conhecimento na área de formação técnica, espera-se raciocínio lógico, conhecimentos básicos em informática, facilidade com novas tecnologias e aplicativos, leitura e escrita profissional, eficiência, 
comunicação adequada, comprometimento, dinamismo, facilidade para trabalhar em equipe e um pouco de ambição para crescimento pessoal e profissional.

Quanto ao perfil gerencial, almeja-se, além das características destacadas para o setor técnico, conhecimentos administrativos básicos nas áreas de finanças, gestão de pessoas, gestão estratégica, economia e técnicas de negociação; visão sistêmica. e integridade. Já para o setor administrativo, além de conhecimentos administrativos, são previstos conhecimentos básicos em informática, facilidade com novas tecnologias e aplicativos, facilidade de relacionamento interpessoal, conhecimento na área de formação técnica, leitura e escrita profissional, equilíbrio emocional, educação, integridade, honestidade e comprometimento.

As deficiências técnicas observadas pelos respondentes devem-se, segundo eles, à falta de formação profissional, de treinamento e de interesse pessoal. Já as deficiências comportamentais são associadas ao perfil pessoal inadequado a determinadas funções, a falta de acompanhamento, orientação e treinamento. Entre as estratégias sinalizadas como importantes para aprimorar os perfis técnico e comportamental nos próximos treinamentos, eles destacam os resultados da pesquisa-ação como ponto de partida e a consideração dos seguintes aspectos no planejamento das ações de capacitação: área geográfica e cultura regional; níveis intelectuais diferentes em um mesmo cargo; nível de motivação; fator de injustiça ou ciúmes dentro de determinada equipe; definição de recompensas; e formação de orientadores pessoais (mentores).

Em relação às ferramentas de $\mathrm{Bl}$, de acordo com os respondentes, a empresa tem desenvolvido sistemas de TI para o gerenciamento dos colaboradores que atuam em campo, que permitem o controle de frota em tempo real, a marcação de ponto por voz e o controle interno de custos. A empresa, porém, não conta com ações específicas de GC.

Os dispositivos utilizados para a comunicação entre as equipes são smartphone e notebook, com destaque para o uso de chamadas telefônicas, Skype e e-mail. A maioria dos equipamentos tem acesso $3 G$ e sistema operacional Android. Em relação à eficácia da comunicação entre equipe técnica e supervisores, destacam-se falhas relacionadas, até mesmo, à forma como cada supervisor trata tecnicamente cada tipo de situação. Desse modo, destaca-se a necessidade de alinhamento entre os supervisores para a definição de padrões e diretrizes básicas de atuação, conforme direcionamento da empresa. 
A intranet e o website da empresa disponibilizam apenas documentação técnica e conteúdo sem atualização periódica, sendo que a intranet não é acessível a todos os colaboradores e não conta com ferramenta de registros de acessos. Mudanças feitas em ferramentas de $\mathrm{TI}$ de uso dos colaboradores, por exemplo, não são claramente discutidas e divulgadas, gerando frustações e perda de tempo a todos os envolvidos. Eventos de confraternização, por sua vez, ocorrem de forma não estruturada, em algumas regiões e, na maioria das vezes, por iniciativa dos próprios colaboradores.

Verifica-se que poucos colaboradores têm a noção clara de suas funções e de seu papel profissional e social. O estudo identifica, ainda, que muitos não têm conhecimento da empresa onde trabalham, uma vez que são remanejados de outras organizações, vencedoras nas licitações anteriores, e nem todos participam de atividades de integração. Neste sentido, observa-se colaboradores que, além de usarem e-mails pessoais, não se identificam como colaboradores da empresa estudada em seus e-mails e redes sociais. Somado a isso, os gestores relatam alta taxa de turnover (renovação de colaboradores por conta de pedidos de demissões).

A comunicação com os clientes e fornecedores ocorre por meio de conversas telefônicas, e-mail e reuniões, quando o contato é necessário. De acordo com o gerente de operações, a comunicação com os clientes demanda habilidade e conhecimento do gerente ou do coordenador, que precisam ser capacitados a entender as necessidades mútuas e buscar as melhores formas de colaboração e crescimento conjunto. Foram destacadas, ainda, deficiências na comunicação sobre ocorrências entre técnicos e supervisores, o que, segundo os gestores respondentes da pesquisa, poderiam ser superadas com treinamentos.

As falhas na comunicação relatadas pelos gestores têm resultado em prejuízos para a empresa, pois, devido a não compreensão das informações trocadas entre os colaboradores e à falta de uma relação de contatos internos (e-mail, telefone, local de atuação, ORM atendida, entre outros dados), têm ocorrido retrabalhos e atrasos na execução das operações. Destaca-se que muitas dificuldades técnicas poderiam ser evitadas ou resolvidas por meio da consulta aos acervos e manuais disponibilizados pela empresa na intranet.

A troca de ocorrências e de boas práticas do dia a dia da empresa não é estruturada, mas feita de modo informal e regionalizada. A empresa investiu na 
plataforma do Google, porém ainda não explorou as possibilidades das ferramentas para padronizá-las e torná-las e efetivas para a promoção da comunicação interna.

\subsection{PERFIL DE APRENDIZAGEM DOS COLABORADORES}

A fim de complementar a etapa de observação e desenvolver uma análise a partir de mais dados sobre o $\mathrm{Cl}$ da empresa estudada, propôs-se a aplicação da Ferramenta de Identificação do Perfil de Aprendizes (FIPA), desenvolvida por Bativa (2011), com base na teoria das inteligências múltiplas de Gardner. Para Gardner (1995), inteligência é a capacidade de resolver problemas ou de elaborar produtos que sejam valorizados em um ou mais ambientes culturais ou comunitários. O autor identificou nove inteligências que funcionam de modo integrado para resolver problemas. São elas: corporal-cinestésica, espacial, existencialista, interpessoal, intrapessoal, linguística, lógico-matemática, musical e naturalista. Os indivíduos possuem cada uma dessas capacidades em certa medida e se diferem no grau de capacidade e na natureza de sua combinação.

O teste conta 80 questões de múltipla-escola, com cinco alternativas cada. Ao finalizá-lo, o usuário tem acesso a um relatório com percentual de inteligências identificadas, a partir de suas respostas, e com a descrição das características de seu estilo de aprendizagem predominante. Desse modo, a partir do levantamento das inteligências múltiplas que se destacam entre os colaboradores, objetiva-se propor ações de EC que atendam ao perfil de aprendizagem da maioria.

O teste foi aplicado nos meses de dezembro de 2013 e janeiro de 2014, a partir de divulgação por e-mail, e contou com a participação de 200 colaboradores, o que corresponde a $25,4 \%$ do total neste período. Participaram colaboradores com atuação em todas as regiões da empresa, sendo $68,5 \%$ do setor técnico, $26 \%$ do gerencial e $5,5 \%$ do administrativo. O resultado geral revela que $34,3 \%$ da amostra de colaboradores têm a inteligência lógico-matemática predominante, seguida pela interpessoal (18\%) e pela musical (12,9\%). Veja gráfico 3. 
Gráfico 3 - Inteligências múltiplas predominantes entre os colaboradores da empresa de implantação e O\&M

Lógico-matemática

Interpessoal

Musical

Naturalista

Corporal-cinestésica

Intrapessoal

Linguística

Espacial

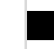

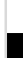

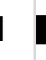

\section{+1.}

\section{-}
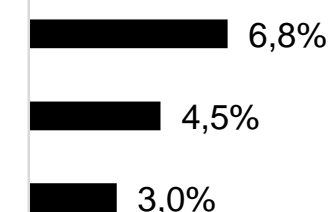

$4,5 \%$

Fonte: Autora.

Ao comparar os resultados por setores de atuação, observa-se que, enquanto nos setores gerencial e técnico prevalece a inteligência lógico-matemática seguida pela interpessoal, no setor administrativo os resultados se invertem: interpessoal (45,5\%) seguida pela lógico-matemática (27,3\%). Veja gráfico 4 .

Gráfico 4 - Inteligências múltiplas por setores de atuação da empresa de implantação e O\&M

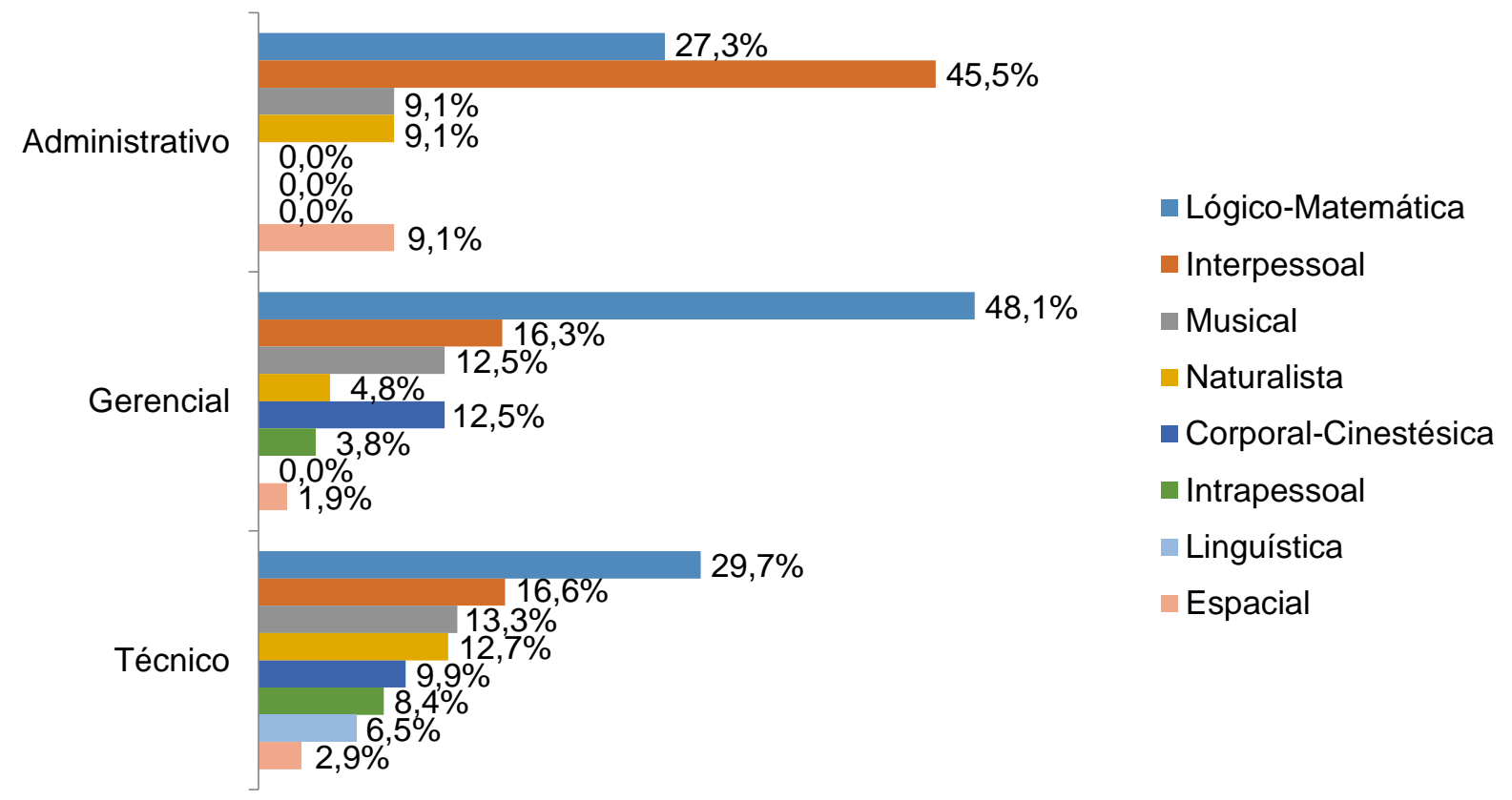

Fonte: Autora. 
De acordo com Gardner (1995), a inteligência lógico-matemática caracteriza-se pelo uso e avaliação de relações abstratas, com processo rápido de resolução de problemas. A inteligência interpessoal, por sua vez, refere-se à capacidade de compreender outras pessoas e à facilidade de comunicação, baseando-se na capacidade nuclear de perceber distinções entre os outros, como contrastes em seus estados de ânimo, temperamentos, motivações e intenções. Já a inteligência musical permite aos indivíduos que a desenvolvem comunicar e compreender significados compostos por sons, pois a notação musical oferece um sistema simbólico acessível e lúdico.

\subsection{ANÁLISE E PLANEJAMENTOS DAS AÇÕES}

A partir do levantamento inicial de dados e informações, foram realizadas reuniões presenciais e online com o presidente e com os gestores do departamento de treinamento, o que garantiu maior detalhamento do contexto e das demandas da empresa estudada. Primeiramente, é possível identificar a falta de registros da empresa em relação a seus processos de trabalho, boas práticas e, também, a seu $\mathrm{Cl}$. As normas, manuais e documentação técnica estão disponíveis na intranet, porém o acesso a esse canal de comunicação não é aberto a todos os colaboradores e não há divulgação massiva do mesmo.

Em relação à resolução de ocorrências, não há registro de boas práticas e de casos de sucesso, o que se revela essencial à GC e ao modelo de negócio de uma empresa cujos colaboradores não estão inseridos em um mesmo ambiente de trabalho. Desse modo, os técnicos que atuam, na maioria das vezes, individualmente nos sites de todo o país, não contam com espaço para esclarecer dúvidas e compartilhar inovações no atendimento às ocorrências diárias. Neste sentido, um banco de dados, que reunisse os registros de ocorrências e as boas práticas, poderia otimizar o tempo gasto em casos de reincidências de um mesmo problema em locais distintos.

Observa-se, também, deficiências quanto ao registro de dados dos colaboradores, que são coletados somente no ato de admissão, cabendo a esses sinalizar ao setor de RH sobre alterações em relação à sua vida pessoal e profissional. Desse modo, além de dificultar a análise periódica da formação e atualização dos colaboradores e, consequentemente, o planejamento de ações de EC adequadas às 
deficiências detectadas, o não conhecimento do ativo humano resulta na falta de engajamento e motivação citadas pelos respondentes, mas requeridas nos perfis desejados pela empresa.

A estruturação de um canal efetivo de comunicação interna apresenta-se, portanto, como uma demanda que visa a agregar diretamente à GC, na medida em que objetiva promover a integração dos colaboradores em um mesmo espaço de acesso às informações institucionais e de troca de experiências. Além de ter divulgação massiva e atualização periódica, este canal deve reunir dados dos colaboradores, facilitando o contato entre equipes e diferentes setores e estreitando a relação entre supervisores e técnicos.

O canal de comunicação interna deve contar, ainda, com acesso móvel, uma vez os smartphones são ferramentas de trabalho, ampliando a interação entre equipes que atuam em diferentes regiões do país, em qualquer hora e lugar onde o colaborador esteja. Esta ferramenta deverá configurar uma ação de promoção da cultura corporativa, o que se torna relevante, principalmente, considerando que a maioria dos colaboradores têm menos de quatro anos de empresa (ver gráfico 5).

Gráfico 5 - Anos de empresa dos colaboradores da empresa de implantação e O\&M

0 a 4

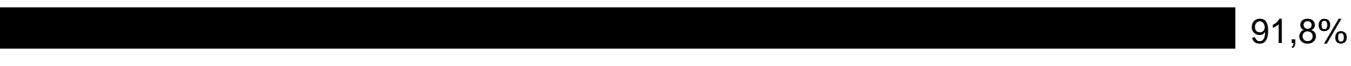

5 a $9 \square 6,5 \%$

10 a 14 】 $1,0 \%$

15 a 19 | $0,6 \%$

20 a $24 \mid 0,1 \%$

Fonte: Autora.

Ao se propor a promover a cultura corporativa, o canal de comunicação interna deve reunir informações institucionais e, também, relacionadas à área de atuação da empresa; procedimentos de trabalho e suas respectivas atualizações; e divulgação de eventos, ações de EC e promoções, além de espaços para troca de experiências, sugestões, críticas e esclarecimento de dúvidas. Desse modo, objetiva-se reduzir a distância física entre os colaboradores, integrando-os ao contexto organizacional. Esta integração e o acesso ao dia a dia da empresa demandam o uso exclusivo do e- 
mail, do telefone e de seus canais de comunicação institucionais, uma vez que, garantindo o acesso às informações, é possível estimular a participação e a identificação dos colaboradores como membros da empresa.

A inserção ao contexto da empresa deve ocorrer também por meio da estruturação de um programa de $\mathrm{EC}$, que atenda às demandas de todos os setores da empresa, à crescente expansão do número de colaboradores e à dinâmica de constante atualização tecnológica, que caracteriza o mercado de telecomunicações. Verifica-se que a empresa procura promover o engajamento dos profissionais quando esses ainda estão nas escolas técnicas, por meio de palestras e da apresentação dos equipamentos mais modernos. Esta proposta deve, portanto, ser estendida para a fase pós-contratação, mantendo-se ao longo de toda a trajetória do colaborador na empresa por meio de um processo de educação continuada. Um dos caminhos para manter a motivação dos profissionais com mais tempo de atuação consiste em formar multiplicadores, ou seja, colaboradores mais experientes que devem dedicar um tempo de seu trabalho na monitoria e orientação dos mais novos, de modo integrado ou complementar às ações de EC.

Em relação a essas ações, identifica-se a necessidade de desenvolver cursos e atividades não apenas de atualização, mas também de capacitação, considerando a baixa qualificação mencionada pelos gestores e a necessidade de nivelamento do conhecimento técnico para a padronização na prestação de serviços. Considerando, portanto, a necessidade de capacitar além de atualizar, o número expressivo de colaboradores, a dispersão geográfica dos mesmos, a faixa etária média e a durabilidade dos treinamentos introdutórios atuais (superior a um mês), vislumbra-se a EAD como uma alternativa para a EC. A partir da pré-disposição da empresa, que já utiliza o Moodle para aplicar questionários de avaliação de conhecimento técnico, observa-se a necessidade de testar a receptividade dos colaboradores e o desempenho de cursos e atividades desenvolvidos para realização a distância, considerando-se formatos, linguagens e propostas de interação adequados.

Os resultados do teste de perfil de aprendizagem também devem ser considerados no desenho de soluções e de recursos educacionais. Em relação às formas de aprendizagem, considerando as inteligências múltiplas, Armstrong (2000) propõe atividades, materiais e estratégias. Como exemplo, para a inteligência lógicomatemática, o autor relaciona atividades como enigmas, solução de problemas, experimentos científicos, cálculos mentais, jogos numéricos e pensamento crítico, que 
podem ser apresentadas no formato de materiais como jogos matemáticos a partir de estratégias que preveem estruturação e experimentação lógica. Para a inteligência interpessoal, destacam-se atividades de aprendizagem cooperativa, tutoramento de colegas, envolvimento na comunidade, reuniões sociais e simulações, que podem ser apresentadas, por exemplo, por meio de jogos de tabuleiro, a partir da estratégia de ensinar algo, colaborar e interagir a respeito dele. Já em relação à inteligência musical, são relacionadas atividades para aprendizagem rítmica e músicas que ensinam, que podem ser apresentadas, por exemplo, por meio de dispositivos que reproduzem áudio e a partir de estratégicas como cantar, compor e escutar músicas.

A proposta de alcançar todos os colaboradores a qualquer hora e em qualquer lugar também deverá ser considerada no planejamento das ações de EAD. A aprendizagem móvel apresenta um amplo repertório de aplicações ao integrar comunicação móvel com educação, melhorando a eficiência do processo de aprendizagem e de trabalho e mobilizando os interesses dos aprendizes em aprender (ZHUANG; YAN; XIAOYAN, 2009). Rosen (2009) destaca duas razões para as organizações desenvolverem treinamentos disponibilizados via mídias móveis: o acesso onde quer que os estudantes/colaboradores estejam e o uso do dispositivo que eles já usam no dia a dia.

Faz-se relevante considerar, também, avaliações conceituais, de reação e de desempenho, que retratem o impacto das ações, tanto em nível de agregação de conhecimento, como na atuação prática, no dia a dia de trabalho. Em todo o processo de estruturação das ações e dos métodos de avaliação, devem constar as deficiências identificadas na atuação dos colaboradores e as competências definidas como desejáveis ao bom desempenho da empresa.

\subsection{PROVAS DE CONCEITO}

A partir da análise do contexto da empresa estudada e da identificação de possíveis caminhos para se estruturar um modelo de GC para o setor de infraestrutura de telecomunicações, foram definidas quatro provas de conceito. São elas: desenvolvimento de um site interno; criação de um curso online voltado a todos os colaboradores da empresa; elaboração de um curso voltado ao setor técnico; e produção de um jogo sério. 
Além de testar a receptividade das propostas e propor possíveis soluções às demandas da empresa estudada, esta fase de ação da pesquisa visa, também, a envolver os gestores do departamento de treinamento no processo produtivo de desenvolvimento dos recursos educacionais.

Com este objetivo, foram realizadas reuniões frequentes com a equipe para a identificação dos conteúdos adequados às provas de conceito e para a definição de grupos de controle, assim como das formas de divulgação e avaliação das ações. $O$ contato próximo possibilitou, ainda, absorver melhor a cultura corporativa da empresa, facilitando o processo de desenvolvimento das provas de conceito e ampliando a compreensão sobre o contexto da empresa estudada. Além da pesquisa bibliográfica, nesta fase, foram considerados processos utilizados por empresas comerciais, que atuam na área de EC.

\subsubsection{Site interno}

A criação do site interno, com acesso restrito aos colaboradores, visa a atender, principalmente, às demandas de comunicação interna e de registro de dados essenciais ao processo de GC. Inicialmente, foi estudada a proposta de reformular a intranet, ideia descartada devido à necessidade de investimento financeiro significativo para a disponibilização de acesso a todos os colaboradores. Desse modo, como a empresa estudada já utiliza contas de e-mail do Google, optou-se pelo Google Sites, que disponibiliza acesso móvel e responsivo, o que é essencial à inclusão de todos, independentemente dos dispositivos utilizados

Como o objetivo da pesquisa é testar ações, a fim de conceber um modelo de $\mathrm{GC}$, o foco para a construção do site interno voltou-se à praticidade e à objetividade, sem preocupação demasiada com layout e sem a contratação de terceiros, o que garante a aplicabilidade da proposta a outros contextos, sem custos elevados. As figuras 3 e 4 apresentam a tela principal do site interno, acessados de um notebook e de um smartphone, respectivamente. 
Figura 3 - Tela principal do site interno acessada de um notebook

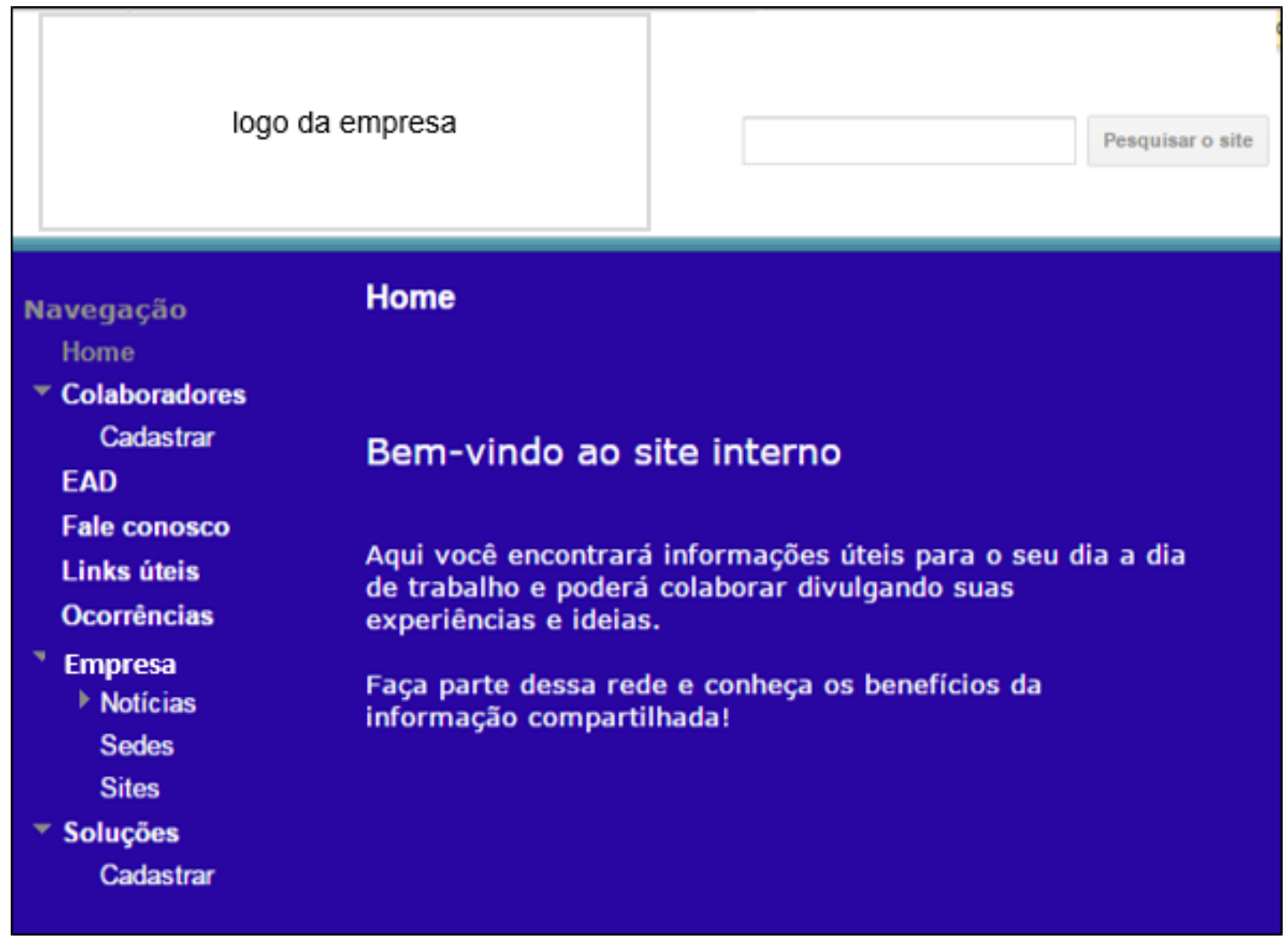

Fonte: Autora.

Figura 4 - Tela principal do site interno acessada de um smartphone

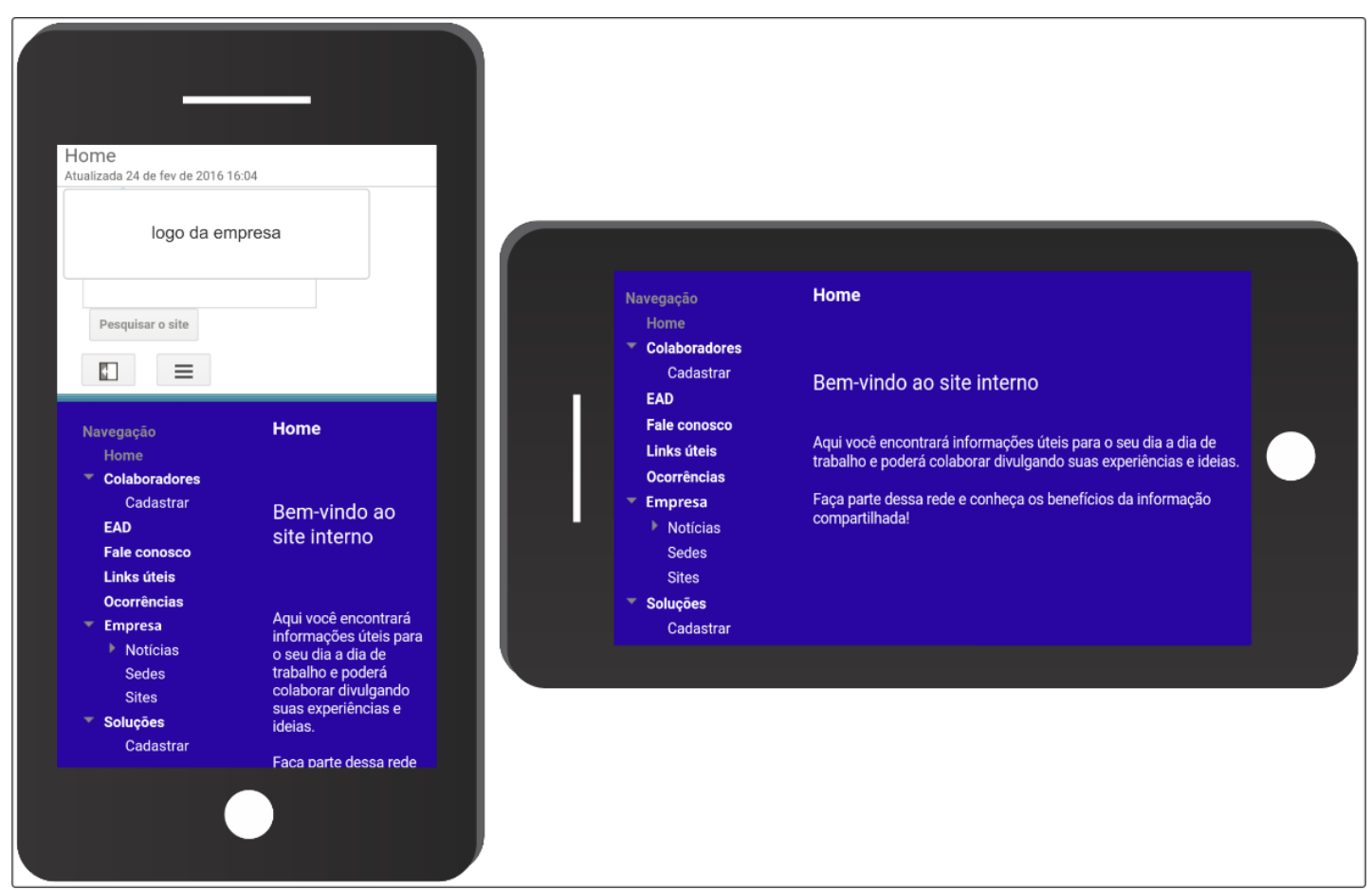

Fonte: Autora. 
A fim de ampliar a compreensão sobre o perfil dos colaboradores, garantir a facilidade de atualização periódica e, ainda, disponibilizar seus dados de contato, facilitando a comunicação e o acesso a equipes de lugares distintos, foi desenvolvido um formulário de cadastro, utilizando a ferramenta de formulários do Google. Ao finalizar o cadastro, automaticamente a planilha de contatos é atualizada, disponibilizando dados, como função, região de atuação, telefone e e-mail, com filtros que facilitam a busca. A ferramenta de formulários foi utilizada, também, para a elaboração de um cadastro de ocorrências, que visa a iniciar o processo de registro de atendimentos realizados pela empresa, permitindo-a, posteriormente, identificar deficiências, prever eventos, sinalizar medidas preventivas aos clientes e padronizar processos.

Considerando a dispersão geográfica dos colaboradores e a atuação individual dos técnicos nos sites, foi desenvolvido um formulário de cadastros de casos e soluções, a fim de promover o compartilhamento de experiências. Este formulário também gera, automaticamente, uma página com a relação de soluções cadastradas, que apresenta os seguintes itens: categoria e análise da ocorrência, solução, tempo gasto na resolução do evento, identificação do site, local, técnico responsável e fontes utilizadas (colega de trabalho, manuais, gestor, etc.). Por se tratar de uma ferramenta nova, todos os campos do cadastro de soluções foram descritos detalhadamente, facilitando a identificação das informações requeridas.

Além de complementar o banco de dados sobre ocorrências, este recurso visa a otimizar o tempo despendido na resolução de eventos, por meio da consulta de casos semelhantes ocorridos em diferentes locais do país. Desse modo, será possível identificar, também, os técnicos que buscam inovar em seu trabalho, a fim de, posteriormente, criar medidas de recompensas, como promoções ou visibilidade e, consequentemente, motivar o comportamento engajado na empresa.

Em relação à divulgação da história da empresa, das notícias institucionais e relacionadas à sua área de atuação, de suas sedes e dos sites aos quais presta serviços, foi criada a página "empresa". Este espaço visa a integrar os colaboradores, disponibilizando informações relevantes que impactam seu trabalho. Desse modo, pretende-se estabelecer uma cultura corporativa, focada na transparência e na troca de informações e experiências. Também com este foco, foi criado um formulário de "fale conosco", para sugestões, críticas e esclarecimento de dúvidas, além de uma pesquisa de satisfação, disponibilizada na página de abertura do site. 
A pesquisa de satisfação foi desenvolvida a fim de conhecer a percepção dos colaboradores e, assim, ampliar a compreensão da empresa estudada. Sua elaboração teve como base as questões desenvolvidas pela Fundação Instituto de Administração - FIA (2011), por meio do Programa de Estudos com Gestão de Pessoas (PROGEP), que constitui a pesquisa que define as melhores empresas para se trabalhar no Brasil. A partir das 64 questões da pesquisa, foi elaborado um questionário com 33 objetivas e sete dissertativas, entre cópias literais, modificações e desenvolvimento de novas questões, específicas ao contexto da empresa estudada (apêndice J).

Para integrar todos os canais de comunicação da empresa em um só lugar, foram criadas as páginas de links úteis, que reúne os acessos ao sistema de gerenciamento da empresa e aos documentos da ISO 9000 (formulários de procedimentos, manuais de procedimentos e manual da qualidade). A página "EAD" reúne informações e acesso ao ambiente virtual de aprendizagem Moodle; aos recursos educacionais (exemplo: vídeos com resolução de exercícios e com guias para utilização de softwares); e ao fórum, espaço criado pela empresa para esclarecimento de dúvidas técnicas.

A figura 5 apresenta a descrição simplificada das páginas do site interno. Seu desenvolvimento demandou três meses de produção e três meses de revisão e validação. Com a autorização do presidente da empresa, a divulgação ocorreu em novembro de 2015, com envio de e-mail institucional a todos os colaboradores.

Figura 5 - Descrição dos itens do menu do site interno

\begin{tabular}{||ll|}
\hline $\begin{array}{l}\text { Navegação } \\
\text { Home }\end{array}$ & $>$ página de abertura \\
Colaboradores & $>$ página para cadastro e acesso aos contatos dos colaboradores \\
Cadastrar & $>$ links para acesso ao Moodle, fórum e recursos educacionais \\
EAD & $>$ formulário para envio de dúvidas, sugestões e críticas \\
Fale conosco & $>$ links para o sistema de gerenciamento e para os documentos da ISO 9000 \\
Links úteis & $>$ página para registro de ocorrências \\
Ocorrências & $>$ página com resumo do histórico da empresa, endereços das sedes, \\
$\nabla$ Empresa & geolocalização de sites atendidos e notícias institucionais ou relacionadas \\
$\triangleright$ Noticias & à área de atuação da empresa \\
Sedes & $>$ página para acesso/registro de cases \\
Sites &
\end{tabular}

Fonte: Autora. 
De acordo com dados do Google Analytics, em três meses, o site interno foi acessado por 2000 usuários (novos e recorrentes), contabilizando 3518 sessões, com duração média de acesso de cinco minutos por sessão (período em que um usuário fica ativamente engajado no website). As páginas mais acessadas foram, respectivamente: Empresa, Colaboradores, Pesquisa de Satisfação e EAD. Em relação à forma de acesso, 88,2\% utilizaram desktops, $11,6 \%$ dispositivos móveis e $0,2 \%$ tablets.

Em relação ao cadastro de ocorrências e de soluções, o acesso não foi satisfatório, com duas e três participações, respectivamente, o que revelou a necessidade de desenvolver uma estratégia de divulgação envolvendo os gestores, uma vez que se trata de ferramentas novas e que nem todos os colaboradores acessam o e-mail corporativo. O formulário "fale conosco" contou com seis mensagens neste período, com assuntos diversos, como esclarecimento de dúvidas sobre $\mathrm{RH}$, elogio ao site, questionamento sobre participação em treinamentos, entre outros.

Quanto às informações institucionais, foram publicadas 12 notícias neste período, sobre temas variados, como procedimentos, treinamentos, segurança do trabalho, calendário, entre outros. Já o formulário de cadastro de colaboradores contou com 467 respondentes $(23,8 \%$ do total), disponibilizando informações importantes à empresa e dados de contato a todos que possuem acesso ao site interno. $70 \%$ dos que preencheram o formulário têm até dois anos de empresa, o que demonstra a motivação dos novos colaboradores e a necessidade de engajar aqueles que têm mais tempo de atuação na empresa.

Em relação à escolaridade, mesmo considerando que apenas $23,8 \%$ dos colaboradores preencheram o formulário, observa-se diferenças significativas em relação aos dados da planilha de colaboradores disponibilizada pelo $\mathrm{RH}$ (gráfico 6). Como exemplos, destacam-se: $96 \%$ dos respondentes concluíram o ensino médio (versus $81,1 \%$ da planilha); $24 \%$ a graduação (versus $7,3 \%$ ); e $5 \%$ possuem pósgraduação (versus $0,1 \%$ ). Este contraste sinaliza a necessidade de atualização constante dos dados, o que não ocorre atualmente. 
Gráfico 6 - Escolaridade dos colaboradores da empresa de implantação e O\&M (planilha $\mathrm{RH}$ )

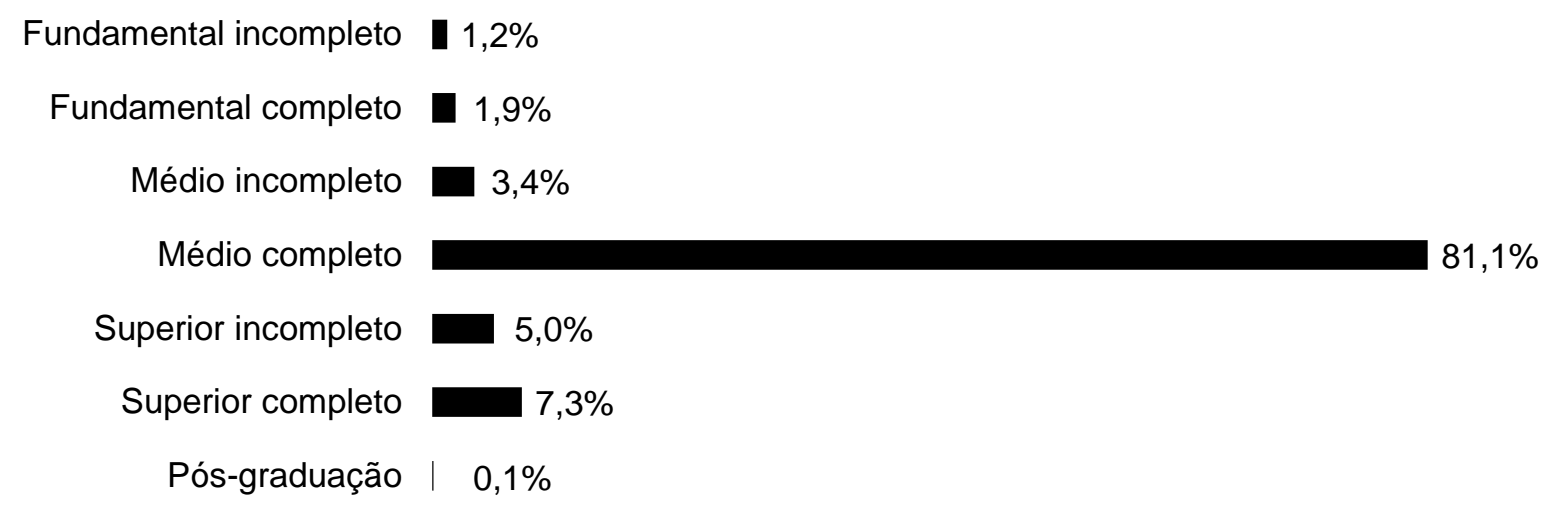

Fonte: Autora.

O formulário permite, também, conhecer os cursos e as instituições de ensino relacionados à formação dos colaboradores, os idiomas, as experiências profissionais anteriores, os treinamentos realizados na empresa e as necessidades de capacitação identificadas por eles. Em relação à área técnica, são coletadas informações sobre o nível de conhecimento técnico em relação a 29 tecnologias utilizadas pela empresa, a partir de uma escala de quatro autoavaliações: não trabalhei ainda/não conheço; conhecimento básico; conhecimento intermediário; e conhecimento avançado.

A pesquisa de satisfação, por sua vez, foi respondida por 477 colaboradores, o que representa $24,3 \%$ do total. Para a análise dos resultados quantitativos, as 33 questões foram organizadas em sete categorias: empresa, trabalho, informações institucionais, ambiente de trabalho, reconhecimento e realização profissional, aprendizado e gestão.

$\mathrm{Na}$ categoria empresa, constam questões sobre recomendação da empresa, relacionamento com o cliente, importância dos serviços para a sociedade, segurança, expectativa de crescimento profissional e abrangência de atuação. Os resultados desta categoria foram positivos, principalmente em relação à troca de experiências entre as equipes e à relevância dos serviços para a sociedade, como apresenta o gráfico 7. É importante destacar, porém, que $21 \%$ dos respondentes não concordam sobre a possibilidade de crescimento profissional na empresa. 
Gráfico 7 - Resultados da pesquisa de satisfação categoria "empresa"

Eu recomendaria a empresa a parentes e amigos, como um excelente lugar para se trabalhar

A empresa entrega a seus clientes aquilo que promete, com alta qualidade

Os serviços da empresa são importantes para nossa sociedade

Trabalhar nesta empresa reflete segurança e tranquilidade para mim e para minha família

Gostaria de conhecer as equipes e as principais ocorrências nos diversos locais nos quais a empresa atua

Acredito que terei a oportunidade de fazer carreira e crescer nesta empresa

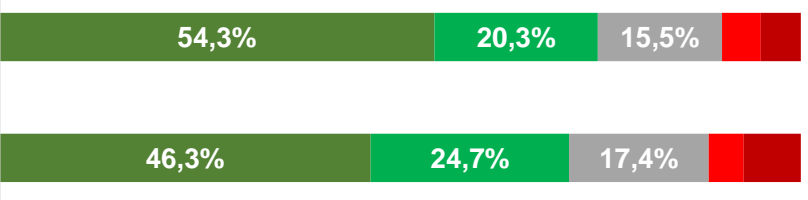

$63,5 \%$ $16,4 \% \quad 8,2 \%$

$41,7 \%$ $27,3 \%$ $14,5 \% \quad 10,3 \%$ $19,5 \% \quad 10,3 \%$

$38,8 \%$ $22,6 \%$ $17,6 \% \quad 10,5 \% 10,5 \%$

m concordo totalmente $\square$ concordo $\square$ indiferente $\|$ discordo $\square$ discordo totalmente Fonte: Autora.

As questões sobre reconhecimento da importância do trabalho para o sucesso da empresa, carga horária, volume de trabalho, equipamentos, procedimentos e métodos foram reunidas na categoria trabalho e avaliadas positivamente pela maioria dos colaboradores (ver gráfico 8). É importante observar, porém, a não concordância de cerca de $20 \%$ dos respondentes em relação ao equilíbrio entre o tempo de dedicação ao trabalho e às demandas pessoais; à adequação do volume de trabalho à carga horária; à disponibilidade de equipamentos; à organização e eficiência dos processos, procedimentos e rotinas; e à discussão dos métodos de trabalho. 
Gráfico 8 - Resultados da pesquisa de satisfação categoria "trabalho"

Reconheço a importância do meu trabalho para

a qualidade do serviço prestado e para a construção da imagem da empresa no mercado

de telecomunicações

Considero que o tempo que dedico ao meu

trabalho é equilibrado entre as necessidades da empresa e as minhas necessidades pessoais e familiares

O volume de trabalho permite que eu termine minhas tarefas no horário previsto

Eu sinto que meu trabalho é importante para que a empresa seja bem-sucedida

Tenho todo o equipamento e o material necessários para realizar bem o meu trabalho

Os processos, procedimentos e rotinas de trabalho são organizados e eficientes

Os métodos para realizar o trabalho na empresa são frequentemente colocados em discussão

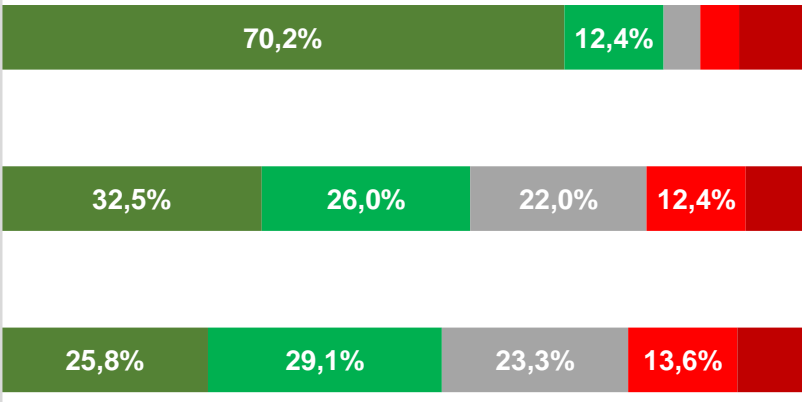

$66,9 \%$ $13,6 \%$ $25,8 \%$ $18,0 \% \quad 9,2 \%$

$24,1 \% \quad 34,6 \% \quad 22,4 \% \quad 11,9 \%$

$22,6 \%$ $28,9 \%$ $12,2 \% 10,3 \%$

$\square$ concordo totalmente $\square$ concordo $\square$ indiferente $\square$ discordo $\square$ discordo totalmente Fonte: Autora.

Em relação às informações institucionais, 57,4\% concordam que recebem todas as informações necessárias à execução do trabalho e 18\% discordam. Quanto à clareza, rapidez e agilidade na transmissão aos colaboradores, 50,3\% concordam e $24,2 \%$ discordam (ver gráfico 9). Desse modo, torna-se relevante ampliar a divulgação dos processos de trabalho e das notícias institucionais, a fim de padronizar os serviços e promover a cultura corporativa. 
Gráfico 9 - Resultados da pesquisa de satisfação categoria "informações institucionais"

Recebo todas as informações necessárias para fazer bem o meu trabalho

As informações sobre a empresa são transmitidas aos empregados com clareza, rapidez e agilidade

\begin{tabular}{|c|c|c|c|}
\hline $31,0 \%$ & $26,4 \%$ & $24,5 \%$ & $11,5 \%$ \\
\hline $23,9 \%$ & $26,4 \%$ & $25,5 \%$ & $14,3 \% \quad 9,9 \%$ \\
\hline
\end{tabular}

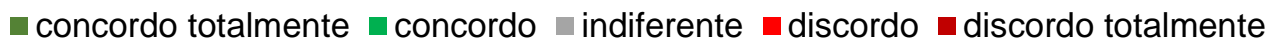

Fonte: Autora.

A categoria ambiente de trabalho, avaliada positivamente por mais de $60 \%$ dos respondentes, reúne questões sobre canais de comunicação da empresa, integração dos setores internos e trabalho em equipe. Destaca-se, no gráfico 10, a motivação para compartilhar experiências, a fim de auxiliar colegas de trabalho, com concordância de $79,4 \%$ dos colaboradores.

Gráfico 10 - Resultados da pesquisa de satisfação categoria "ambiente de trabalho"

O ambiente de trabalho e os canais de comunicação da empresa facilitam o relacionamento entre os funcionários

Quando preciso de outra área da empresa, sou

$\begin{array}{llll}34,6 \% & 28,3 \% & 19,9 \% & 10,5 \%\end{array}$
bem atendido

Sinto que minha equipe trabalha como um verdadeiro time

$38,2 \%$

$30,2 \%$

$15,1 \% \quad 10,9 \%$

Meus colegas estão sempre dispostos a compartilhar comigo o que sabem

Sentiria-me motivado a compartilhar experiências e casos vivenciados na empresa,

a fim de ajudar colegas de trabalho que se deparem com a mesma situação

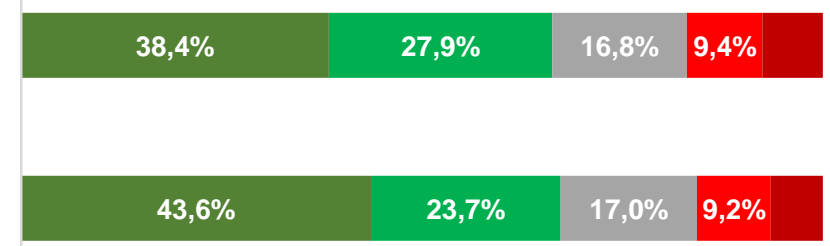

\section{$61,0 \%$} $18,4 \% \quad 8,0 \%$

ancordo totalmente $\quad$ concordo $\square$ indiferente $\quad$ discordo $\quad$ discordo totalmente Fonte: Autora.

Os resultados demonstram, também, a satisfação em relação ao reconhecimento e à realização profissional pela maioria dos respondentes, com destaque para os benefícios e a para a superação de desafios (gráfico 11). 
Gráfico 11 - Resultados da pesquisa de satisfação categoria "reconhecimento e realização profissional"

Sou recompensado, de maneira justa, pela qualidade do trabalho que apresento

A empresa atende adequadamente às minhas necessidades nas áreas de saúde e outros benefícios

A realização profissional pelos desafios superados é a sensação mais frequente que sinto ao sair do trabalho
$25,4 \%$
$28,9 \%$
$21,6 \% \quad 13,6 \%$

$55,8 \%$

$20,5 \% \quad 11,1 \% 7,3 \%$

$45,7 \%$

$25,4 \%$

$14,7 \% 7,3 \%$

m concordo totalmente $\|$ concordo $\quad$ indiferente $\quad$ discordo $\square$ discordo totalmente Fonte: Autora.

Em relação ao aprendizado, 73,5\% concordam que o trabalho realizado permite aprimoramento contínuo. 20,6\%, porém, não se sentem estimulados a buscar novos conhecimentos fora da empresa e 27,3\% discordam sobre a oportunidade igualitária de participação nas atividades de treinamento (gráfico 12). De modo geral, a avaliação é positiva, porém faz-se necessário desenvolver EC a todos os colaboradores, além de estimulá-los a aprender sempre, principalmente pelo fato de a empresa atuar em um setor no qual equipamentos e procedimentos de trabalho mudam com frequência.

Gráfico 12 - Resultados da pesquisa de satisfação categoria "aprendizado"

O trabalho que realizo me permite aprender coisas novas sempre

Sinto-me estimulado a buscar novos conhecimentos fora da empresa

$\begin{array}{lll}50,9 \% & 22,6 \% & 11,3 \% 7,1 \%\end{array}$

Todos têm oportunidade de participar de atividades de treinamento nesta empresa $33,1 \%$ $26,8 \%$ $19,5 \% \quad 11,2 \% 9,4 \%$

m concordo totalmente $\square$ concordo $\square$ indiferente $\square$ discordo $\square$ discordo totalmente Fonte: Autora.

Na categoria gestão (gráfico 13), observa-se avaliação positiva na maioria das questões, com destaque para o conhecimento dos chefes em relação à suas áreas de atuação, às orientações dos gestores e à clareza quanto ao que se espera do trabalho. $62,5 \%$ sentem-se estimulados a contribuir para melhorar a forma como o trabalho é realizado e $51,3 \%$ a conhecer o trabalho dos colegas. Porém, é importante ressaltar 
que 32,3\% declaram que não recebem avaliações de desempenho, o que é essencial para o crescimento profissional do colaborador e para seu engajamento na empresa.

Gráfico 13 - Resultados da pesquisa de satisfação categoria "gestão"

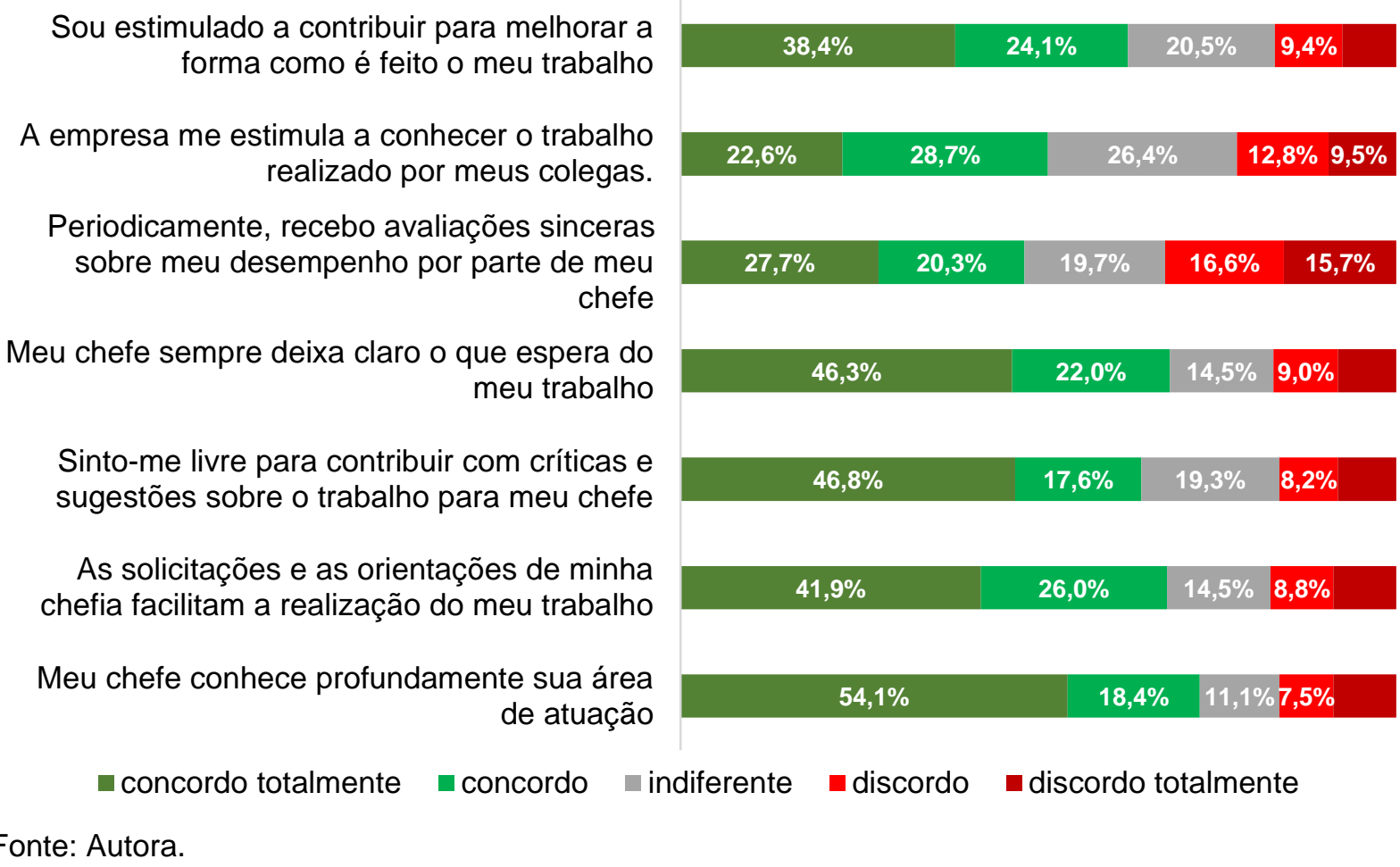

Em relação aos resultados qualitativos, mais de 59\% dos colaboradores contribuíram com sugestões, críticas e opiniões, totalizando 2674 comentários. $\mathrm{Na}$ tabela 1, é possível verificar o total de comentários e respondentes por questão. É importante destacar que a porcentagem se refere ao número de respondentes de determinada questão em relação ao número total de colaboradores que participaram da pesquisa de satisfação (477). Os comentários foram analisados e organizados em categorias identificadas a partir desta análise. Os comentários mais relevantes estão disponíveis no apêndice $\mathrm{K}$. 
Tabela 1 - Resultados qualitativos da pesquisa de satisfação - número de respondentes e comentários por questões

\begin{tabular}{|c|c|c|c|}
\hline Questão & Comentários & \multicolumn{2}{|c|}{ Respondentes } \\
\hline $\begin{array}{l}\text { Que ações a empresa poderia considerar para melhorar a } \\
\text { comunicação entre os colaboradores? }\end{array}$ & 330 & 305 & $64 \%$ \\
\hline $\begin{array}{l}\text { Quais são suas sugestões e críticas em relação aos treinamentos } \\
\text { desenvolvidos pela empresa? }\end{array}$ & 270 & 280 & $59 \%$ \\
\hline $\begin{array}{l}\text { O que você espera de sua atuação na empresa em relação à } \\
\text { satisfação pessoal e profissional? }\end{array}$ & 387 & 329 & $69 \%$ \\
\hline $\begin{array}{l}\text { Você se sentiria motivado a compartilhar suas experiências de } \\
\text { trabalho, a fim de auxiliar outros colaboradores que possam vir a } \\
\text { vivenciar ocorrências semelhantes? }\end{array}$ & 336 & 337 & $71 \%$ \\
\hline Quais são as principais vantagens de se trabalhar na empresa? & 549 & 319 & $67 \%$ \\
\hline Quais são as principais desvantagens de se trabalhar na empresa? & 343 & 287 & $60 \%$ \\
\hline $\begin{array}{l}\text { Quais são suas sugestões para que a empresa se consolide como } \\
\text { uma excelente empresa para se trabalhar? }\end{array}$ & 459 & 299 & $63 \%$ \\
\hline
\end{tabular}

Fonte: Autora.

Em relação às ações sugeridas para melhorar a comunicação interna, 330 comentários foram analisados e organizados em 11 categorias principais, conforme verifica-se no gráfico 14. Destacam-se as sugestões de uso e criação de canais internos, reuniões mais frequentes e ações de integração. Entre os comentários, ressaltam-se: a avaliação positiva do site interno como meio de "ouvir" a opinião e as demandas dos colaboradores; a criação de canais de comunicação e redes sociais com histórico da empresa, informações de contratos, regiões de atuação, calendário de $\mathrm{RH}$, entre outros conteúdos; a realização de reuniões regulares, permitindo a participação ativa dos colaboradores; e a promoção de palestras e eventos motivacionais em momentos pontuais, como fusões e ampliação da empresa, a fim de motivar os colaboradores a crescerem na empresa ou mesmo a focarem em um determinado projeto.

Quanto à divulgação de notícias internas, destacam-se: a necessidade de maior clareza sobre a situação da empresa, uma vez há queixas sobre o fato de se ficar ciente de mudanças institucionais por meio de terceiros; e a divulgação de promoções, pois há a sensação de estagnação na empresa. Foram ressaltadas, também, demandas por: maior proximidade com a gerência; troca de informações entre todos os colaboradores; desenvolvimento de cursos sobre novas tecnologias, comportamento organizacional e liderança; ampliação da comunicação entre dispositivos de ORMs distintas; promoção de plano de carreira e avaliação de desempenho; esclarecimento da metodologia de trabalho de cada setor; e maior envolvimento do $\mathrm{RH}$ na divulgação de procedimentos de trabalho e mudanças na empresa. 
Gráfico 14 - Ações a empresa poderia considerar para melhorar a comunicação entre os colaboradores

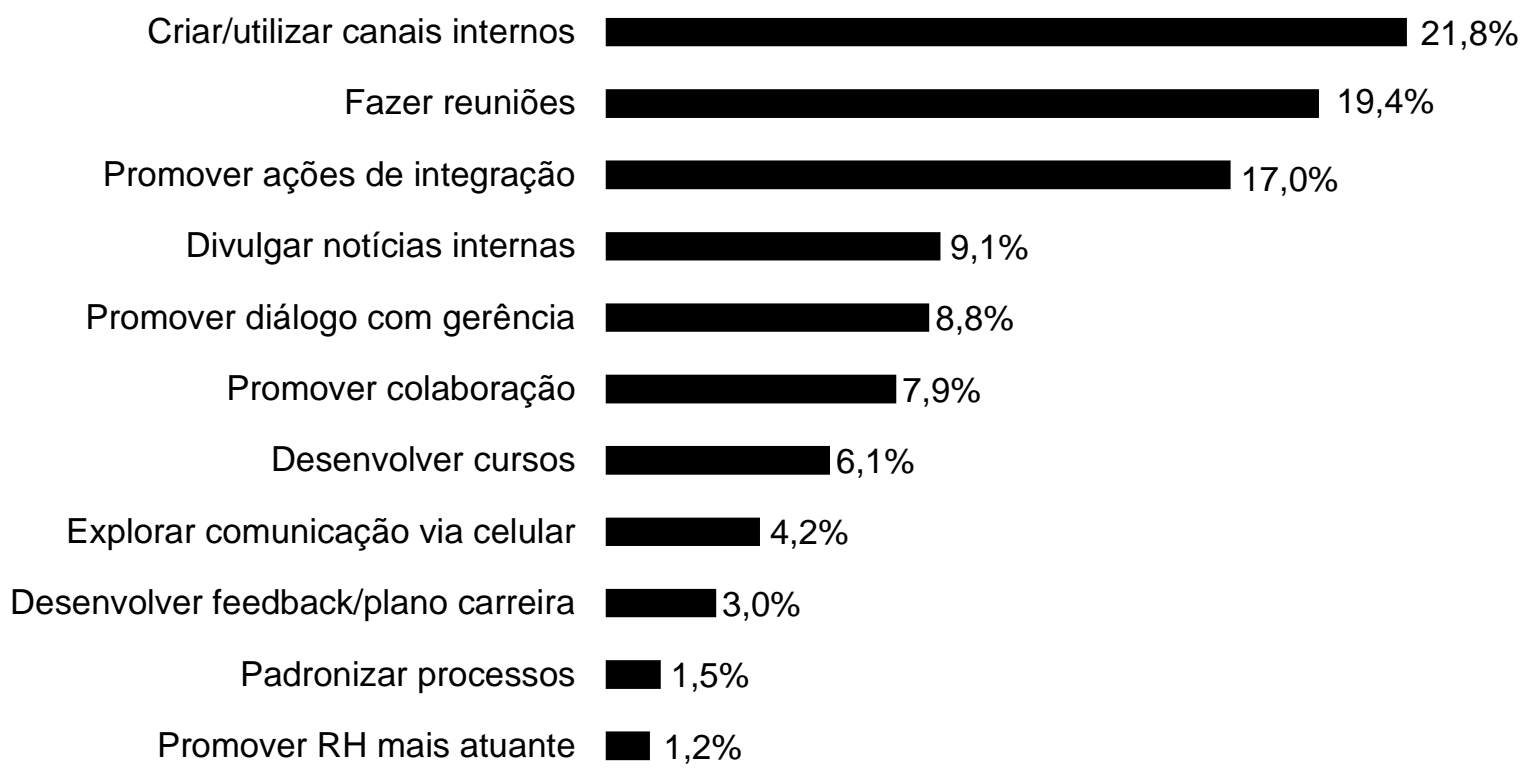

Fonte: Autora.

Em relação aos treinamentos, foram estruturadas 15 categorias a partir dos 270 comentários, entre sugestões e críticas (gráfico 15). A necessidade de se desenvolver mais treinamentos foi apontada por $38 \%$ dos colaboradores, seguida pela demanda por manter a qualidade e pela crítica de não se ter realizado nenhum treinamento até o momento. Destacaram-se comentários com sugestões de treinamentos para o setor administrativo e técnico, de acordo com as mudanças tecnológicas; consulta sobre as dificuldades de campo, a fim de se desenvolver treinamentos mais eficientes; treinamento em campo com equipes experientes; investimento em mais cursos online; investimento em mais cursos presenciais; criação de benefício à formação complementar; desenvolvimento de ações que integrem colaboradores de distintas regiões; formação de tutores e multiplicadores; e criação de um padrão de trabalho. Quanto às críticas, a principal refere-se a não realização de treinamento, destacandose o comentário de um colaborador que trabalha há cinco anos na empresa. 
Gráfico 15 - Sugestões e críticas em relação aos treinamentos desenvolvidos pela empresa

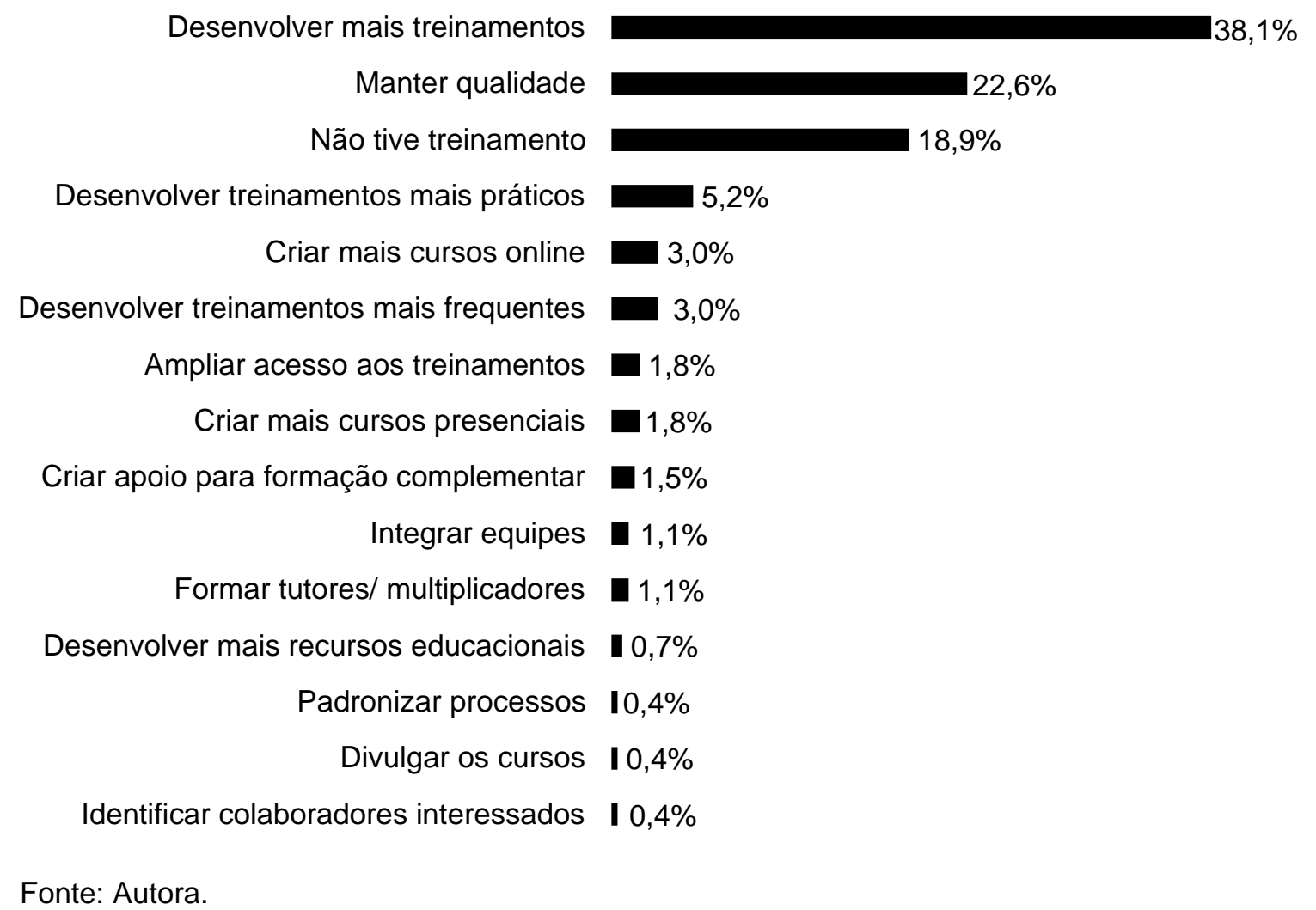

A satisfação pessoal e profissional a partir da atuação na empresa também é abordada nas questões discursivas por 387 colaboradores. A partir dos resultados, foram organizadas nove categorias (gráfico 16). O crescimento pessoal e profissional foi destacado por $29,5 \%$ dos respondentes, seguido pela demanda por reconhecimento $(24,3 \%)$, contribuição a partir do trabalho $(19,4 \%)$ e oportunidade de agregar conhecimento (14,5\%). É importante destacar que 1,5\% não tem perspectivas de crescimento profissional, com comentário sobre a inexistência de plano de carreira, ações de aperfeiçoamento e valorização de grau de estudo.

Entre os comentários, destacam-se: continuar crescendo e aprendendo junto com a empresa; equilibrar trabalho e família; ter reconhecimento financeiro e funcional; receber avaliações sinceras sobre o desempenho; ser o mais proativo possível; ampliar o conhecimento profissional; contar com mais treinamentos; conquistar o respeito dos colegas e com nova postura por parte dos supervisores; focar no cliente; e agregar valor para a empresa, gerando receita e perenidade para a mesma e conhecimento para a carreira profissional. 
Gráfico 16 - O que você espera de sua atuação na empresa em relação à satisfação pessoal e profissional

Crescer pessoal/profissionalmente

$29,5 \%$

Ser reconhecido

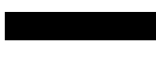

$24,3 \%$

Contribuir com trabalho

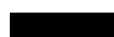

$9,4 \%$

Agregar conhecimento

Trabalhar em equipe

Alcançar metas

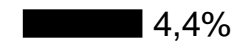

Satisfazer cliente

$2,3 \%$

Agregar valor

$2,3 \%$

Sem perspectivas

$1,8 \%$

$\square 1,5 \%$

Fonte: Autora.

Em relação à questão: "você se sentiria motivado a compartilhar suas experiências de trabalho, a fim de auxiliar outros colaboradores que possam vir a vivenciar ocorrências semelhantes?", 97,9\% dos 336 respondentes responderam positivamente. Entre os comentários, destacam-se: "o compartilhamento de experiências agrega não só conhecimento como também estabelece um vínculo de confiança entre a equipe"; e "não só me sinto motivado, como sempre atuei e atuo desta forma, pois acredito que somente repassando conhecimentos e recebendo conhecimentos alheios é que poderemos construir uma empresa sólida e de sucesso no mercado".

A questão sobre as principais vantagens de se trabalhar na empresa contou com 549 comentários, organizados em 15 categorias (gráfico 17). Os principais comentários são sobre a solidez da empresa, os bons benefícios, a remuneração adequada e a possibilidade de agregar conhecimento. Destacou-se que a empresa está sempre se adequando aos requisitos do mercado; conta com um bom plano de saúde; concede remuneração de acordo com a média do setor, realizando o pagamento com pontualidade; e apresenta sempre novos desafios, proporcionando novos conhecimentos. O ambiente de trabalho agradável também foi citado, assim como a união e a interação entre os colaboradores; as boas expectativas profissionais; o canal de comunicação direto com os gestores; a motivação de se trabalhar em uma área de tecnologia avançada; as ferramentas de trabalho adequadas; o horário flexível; a autonomia; e o comprometimento da empresa com o colaborador. 
Gráfico 17 - Principais vantagens de se trabalhar na empresa

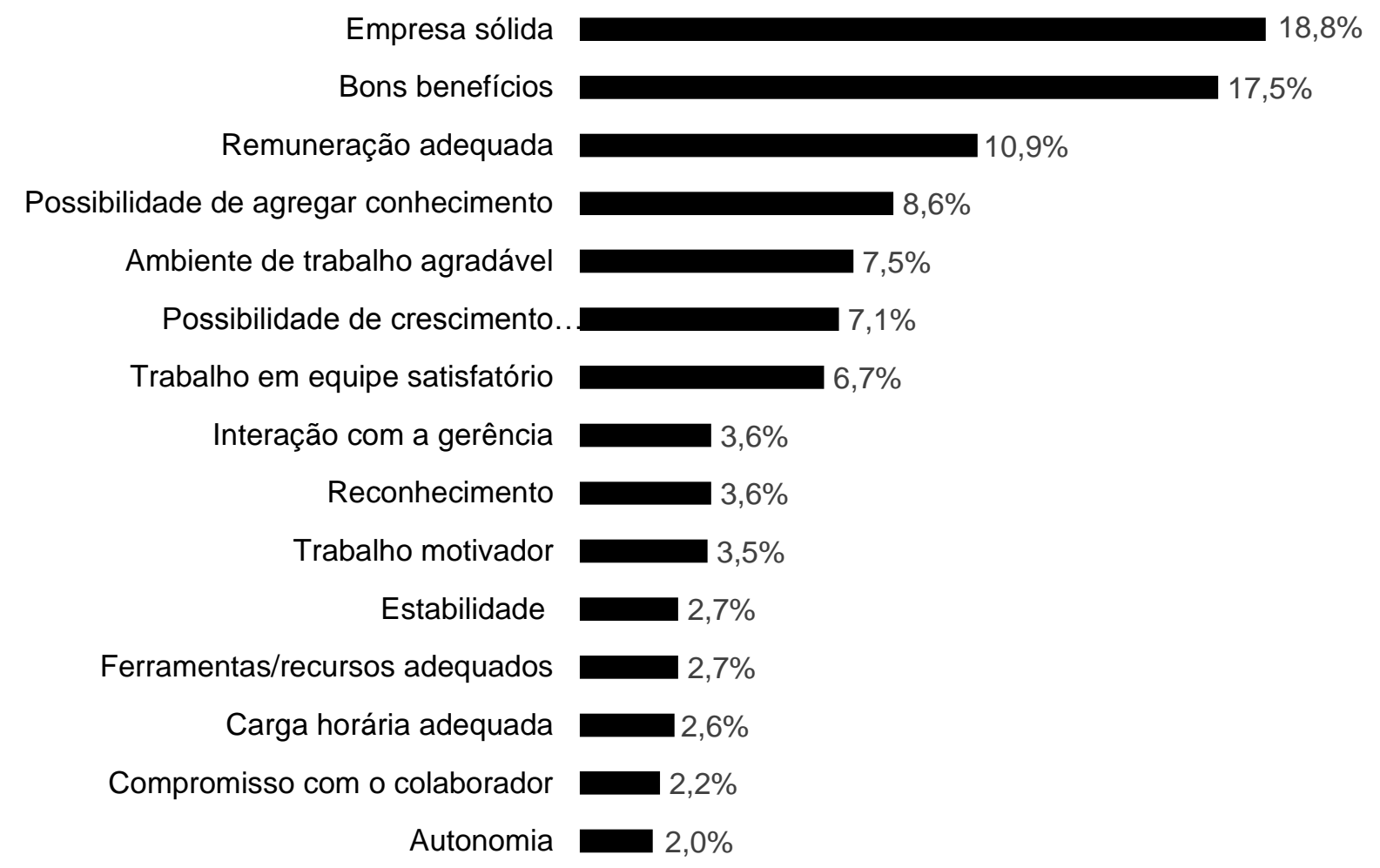

Fonte: Autora.

Sobre as desvantagens, foram 343 comentários, organizados também em 15 categorias (gráfico 18). 31,78\% dos colaboradores não observam desvantagens na empresa, seguidos por $11,37 \%$ que consideram a carga horária excessiva e 7,87\% que destacaram a gestão ineficiente e a remuneração inadequada. É interessante observar que algumas características citadas como vantagens são consideradas desvantagens por outros colaboradores, como, por exemplo, carga horária, remuneração, benefícios, ferramentas de trabalho e reconhecimento. Esta contradição pode representar a perspectiva individual de cada colaborador ou políticas diferenciadas de acordo com o contrato ou a região de atuação. Independentemente da motivação, a padronização de processos e rotinas de trabalho apresenta-se, mais uma vez, como uma demanda importante da empresa.

Entre os comentários, destacam-se: acionamentos em horários diversos, fora do horário comercial; falta de respeito dos gestores com os profissionais de campo; ausência de avaliação de desempenho; ausência de participação nos lucros e resultado (PLR); não atualização dos cargos conforme a atividade exercida; ausência de apoio técnico para a solução de problemas; ausência de treinamentos e espaços 
para compartilhar conhecimentos; setores/projetos que não se comunicam, transformando a empresa em um conjuntos de "ilhas"; e políticas e remuneração diferenciadas para a mesma função.

Gráfico 18 - Principais desvantagens de se trabalhar na empresa

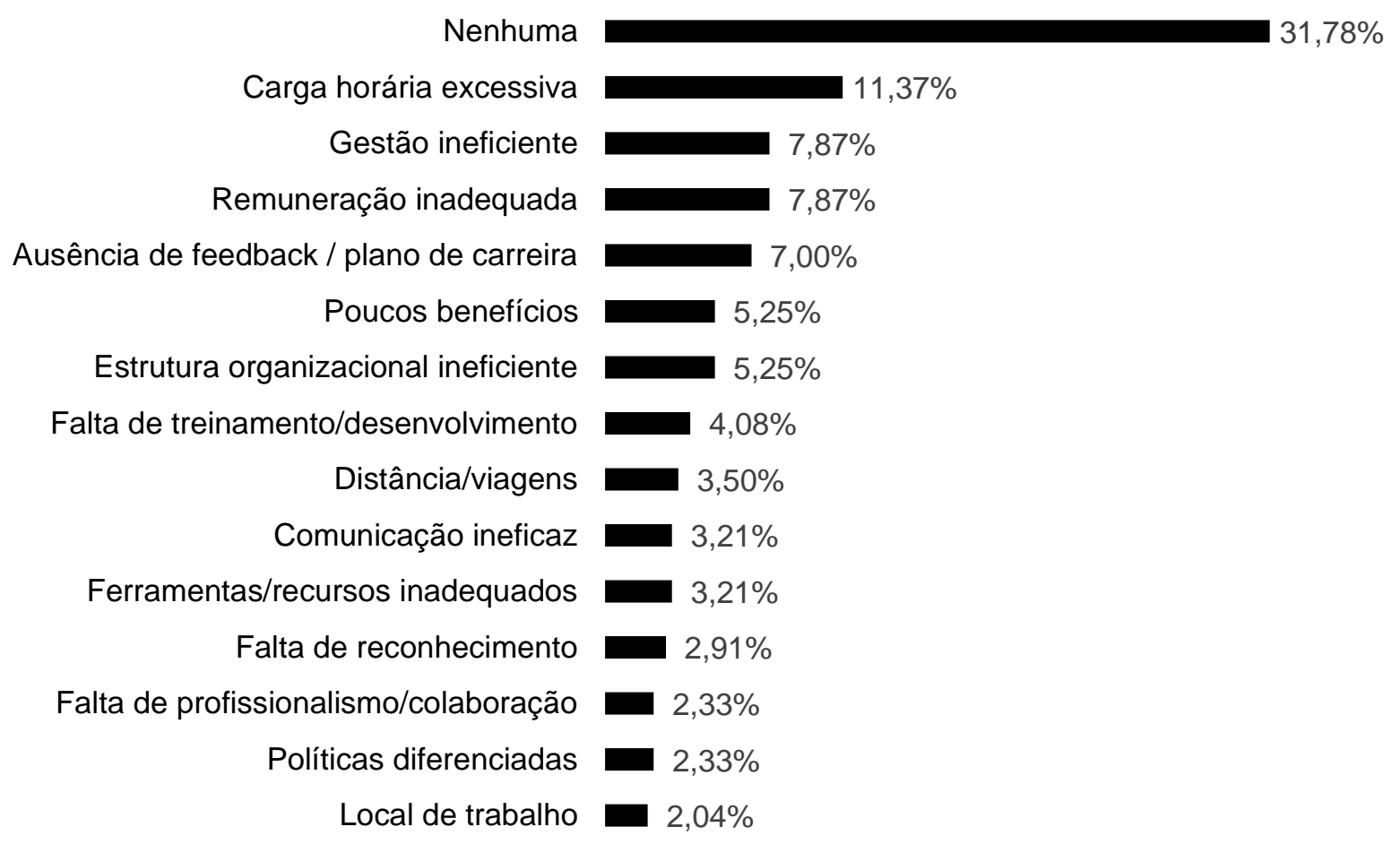

Fonte: Autora.

As sugestões para a consolidação como uma excelente empresa para se trabalhar totalizaram 459 comentários, divididos em 20 categorias (gráfico 19). A promoção de treinamento e desenvolvimento destaca-se como principal sugestão, seguida pelo feedback e plano de carreira, manutenção da qualidade, reconhecimento dos colaboradores e comunicação interna. As sugestões relacionam-se diretamente às desvantagens identificadas na pesquisa.

Desse modo, entre os comentários, destacam-se: melhorar a oferta de cursos de aprimoramento e capacitação, investindo no maior patrimônio, que é o quadro de colaboradores; melhorar a forma de avaliação do profissional para proporcionar crescimento por mérito; buscar a excelência e acompanhar as mudanças na área de telecomunicações; valorizar os profissionais que buscam qualificações; manter canal aberto com os colaboradores, para analisar as dificuldades e procurar adotar algumas sugestões; desenvolver plano de cargos e salários, incentivando os colaboradores a permanecerem na empresa; criar mais iniciativas como essa para conhecer a opinião 
dos colaboradores; estabelecer maior contato entre diretoria e colaboradores para conhecimento dos problemas diários; ter procedimentos/processos bem definidos e que sejam aplicáveis a todos os projetos; ouvir o cliente com mais atenção e com maior frequência; e ter um $\mathrm{RH}$ estratégico com foco nos colaboradores. Um dos colaboradores destaca que "uma grande empresa não se faz com um grande faturamento, mas com grandes pessoas".

Gráfico 19 - Sugestões para que se consolide como uma excelente empresa para se trabalhar

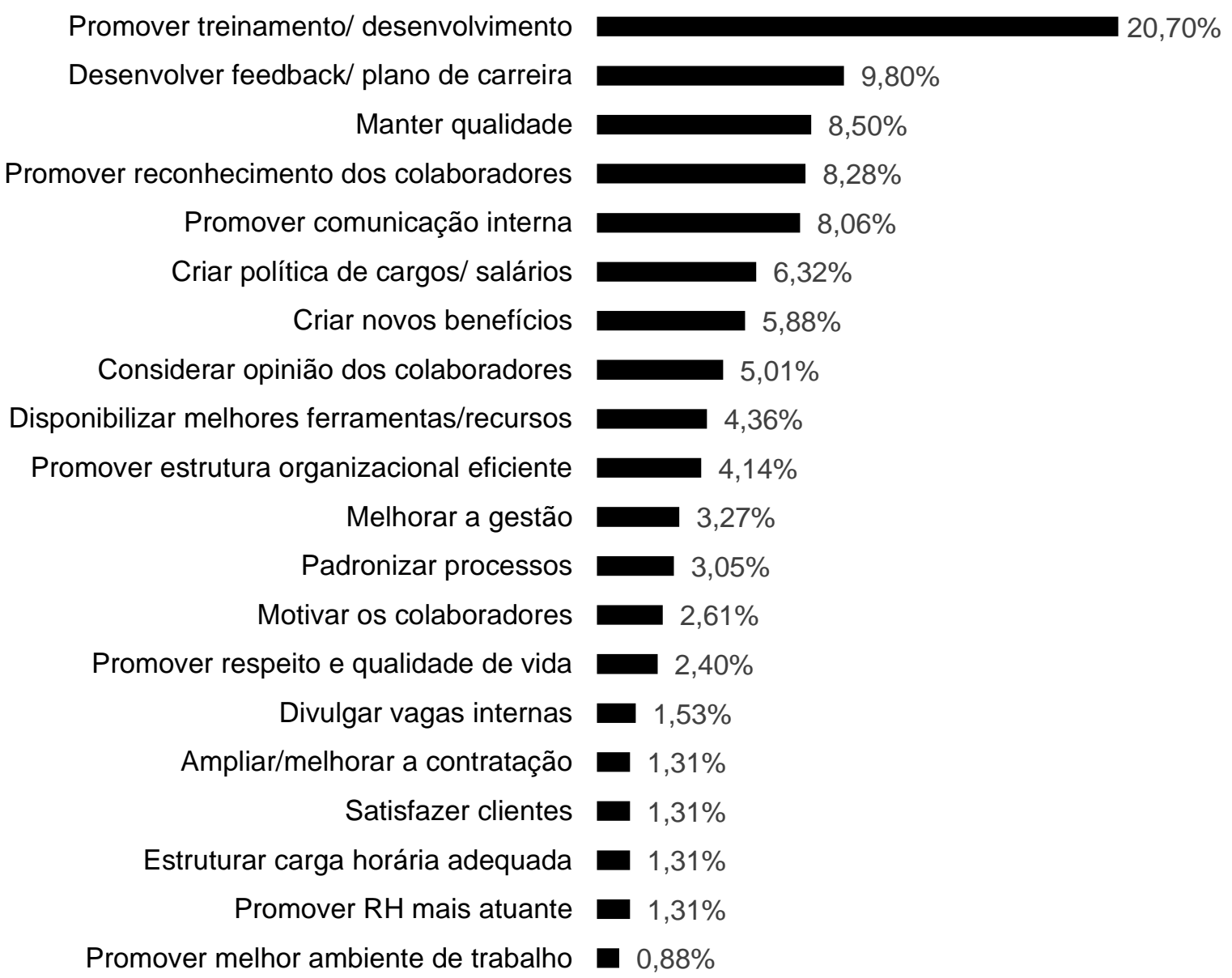

Fonte: Autora.

\subsubsection{Cursos}

De acordo com o levantamento e a análise das demandas da empresa estudada, verifica-se a necessidade de ampliar o acesso à EC, garantindo a capacitação e a atualização dos colaboradores de acordo com a dinamicidade do setor de 
telecomunicações. Desse modo, juntamente com o departamento de treinamento da empresa, foram definidos dois temas para desenvolvimento de provas de conceito: Integração e TCP/IP. O curso Integração volta-se à instrução/divulgação da empresa a todos os colaboradores, com abordagem mais administrativa e comportamental, e o curso de TCP/IP tem como foco na capacitação técnica.

$O$ desenvolvimento dos cursos contou com três etapas principais: estratégia educacional, storyboard e produção. A estratégia educacional consiste em um documento de texto, elaborado com base na análise dos conteúdos sobre o tema, disponibilizados pela empresa, que relaciona objetivos de aprendizagem, estrutura do curso por capítulos, linguagem adequada, recursos tecnológicos disponíveis e propostas de avaliação de desempenho.

Com a validação da estratégia educacional pelos gestores do setor de treinamentos, inicia-se a elaboração do storyboard, com os formatos de objeto de aprendizagem e com os recursos tecnológicos previstos na estratégia educacional. $\mathrm{O}$ storyboard é um arquivo em formato de apresentação de slides, que apresenta o esboço sequencial dos conteúdos, tela a tela, considerando recursos gráficos e visuais, navegabilidade, interações, entre outras características que variam de acordo com os conteúdos abordados. De acordo com Medina et al. (2013, p. 96), "storyboard é uma representação sequencial de uma história ou ação, realizada de modo visual. Pode-se utilizar diversas técnicas para isso, como desenho, fotografias ou colagens".

Após a validação do storyboard pelos gestores, a produção do curso é iniciada. Nesta etapa, a preferência foi por usar um software livre e gratuito, com recursos de produção de fácil usabilidade, considerando as possibilidades de replicação do modelo em outros contextos e a importância do acesso móvel aos cursos. Foi realizada uma ampla pesquisa por meio da Internet e do contato com profissionais da área de EC, resultando na identificação de vários softwares gratuitos, mas que não disponibilizavam acesso móvel.

Optou-se, portanto, pela versão beta do Google Web Designer, desenvolvida para criação de anúncios e animações dinâmicos usando HTML5, CSS3 e JavaScript, sem demandar conhecimento de código. Por se tratar de uma ferramenta nova, em fase beta, e que não tem como finalidade a criação de cursos, foi necessário o estudo de vários tutoriais e participação no fórum da ferramenta, além de pesquisas sobre design responsivo, que garantisse um layout adequado tanto para computadores de mesa e notebooks quanto para dispositivos móveis. 
Devido às limitações da ferramenta no que tange à criação de arquivos mais extensos, com telas sequenciais, como é o caso de um curso, não foi possível produzir todas as animações previstas no storyboard. Porém, foi possível criar provas de conceito que atendem à finalidade da pesquisa acadêmica, sem a necessidade de se contratar equipes de designers e programadores e sem custos para a empresa. Assim, a partir dos resultados das provas de conceito e de acordo com o interesse da empresa, posteriormente, poderá se optar por ferramentas mais robustas, específicas para a produção de cursos online, interativos e dinâmicos.

Observe, na figura 6, imagens relacionadas às etapas de elaboração/ disponibilização dos cursos: storyboard (1), produção no Google Web Designer (2) e curso disponível no Moodle (3). A imagem representada é uma das telas do curso Integração.

A fim de aproximar os gestores do processo de produção e, também, dos colaboradores, a narração dos conteúdos foi feita pelos próprios responsáveis pelos assuntos abordados. Para auxiliá-los neste processo, foram desenvolvidos roteiros de áudio, relacionando capítulos, conteúdos e observações sobre a apresentação gráfica das respectivas telas do curso a serem narradas.

Os cursos produzidos foram disponibilizados no Moodle, estruturados em capítulos, juntamente com chats, fórum de dúvidas, exercícios, enquetes, vídeos e avaliações. Além do interesse inicial demonstrado pelo Moodle por parte da empresa estudada, sua versatilidade e adaptabilidade, somadas ao fato de ser uma ferramenta gratuita e livre, foram fatores decisivos para sua escolha, juntamente com seus recursos que otimizam a GC:

O uso de uma ferramenta como a Moodle facilita a gestão desse conhecimento, através de recursos de virtualização do espaço de aprendizagem, medição de desempenho, disseminação de conteúdo e ambiente colaborativo. Além disso, a ferramenta é uma poderosa plataforma, para cuja evolução uma comunidade de profissionais de todo o mundo contribui diretamente. Seu uso torna-se não só importante, mas indispensável para uma efetiva gestão do capital intelectual de uma organização (CERVEIRA, 2011). 
Figura 6 - Etapas de produção dos cursos online

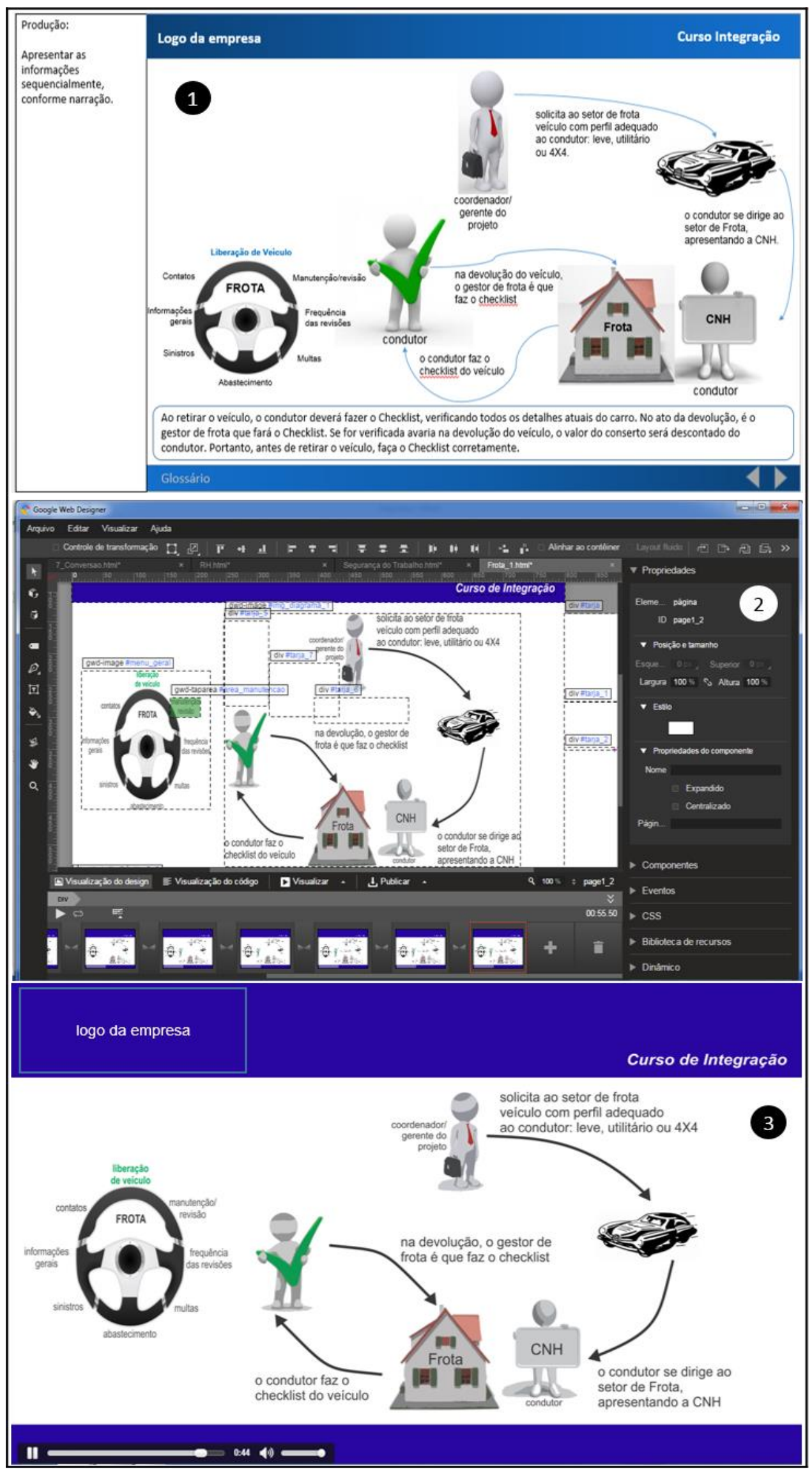

Fonte: Autora. 
O Moodle também possibilita a aprendizagem móvel, com acesso via smartphone, tablets, entre outros dispositivos, caraterística que não só se justifica por se tratar de um setor de telecomunicações, cujos colaboradores contam com smartphones como ferramenta de trabalho, mas, também, pelo fato de grande parte desses trabalharem individualmente, em diferentes regiões do país. Destacam-se, portanto, a mobilidade, que pode ser definida como a capacidade de poder se deslocar ou ser deslocado facilmente; a portabilidade, que é a capacidade de ser facilmente transportável; e a usabilidade, que permite um dispositivo móvel ser utilizável por tipos de pessoas diferentes em diversos ambientes (LEE; SCHNEIDER; SCHELL, 2005).

Em relação às avaliações, foi prevista uma avaliação conceitual para o curso da área técnica, TCP/IP, e avaliações de reação (apêndice L) para ambos os cursos, com questões sobre conteúdo, metodologia, organização, comunicação e recursos educacionais utilizados, perfil de aprendizagem, além de espaço para comentários gerais. Os colaboradores dos grupos de controle avaliaram os temas abordados, a partir de uma escala de cinco alternativas (concordo totalmente, concordo, indiferente, discordo e discordo totalmente).

\subsubsection{Curso Integração}

O curso Integração foi proposto para apresentar a empresa aos novos e, também, aos antigos colaboradores, uma vez que o curso presencial não tem sido ministrado a todos. Desse modo, reúne informações sobre a história da empresa, direitos, deveres e procedimentos que farão parte da rotina do colaborador. O curso conta com oito capítulos: Introdução, Recursos Humanos, Sistema de Gerenciamento, Segurança do Trabalho, Frota, Qualidade, Capacitação e Comunicação. Os conteúdos foram repassados pelos responsáveis de cada área, após conversa presencial sobre a proposta do curso online.

Os dois últimos capítulos foram acrescentados ao curso original, a fim de divulgar as novas ações da empresa em relação à comunicação interna e à EC, com destaque para a proposta do site interno e do Moodle. No capítulo Capacitação, é apresentado um vídeo com o passo a passo para acessar o Moodle. Em Comunicação, destacase a necessidade de usar o e-mail corporativo e os canais internos para acessar as informações institucionais. 
Em relação aos objetivos de aprendizagem, ao final do curso, o colaborador deve estar apto a: compreender todos os direitos e deveres, conhecendo os procedimentos e os documentos necessários a assegurá-los; realizar suas atividades de acordo com as normas de segurança do trabalho e da qualidade; acessar e utilizar todos os sistemas da empresa relacionados a normas e procedimentos; e utilizar os canais de comunicação e EC de forma colaborativa.

Para conhecer um pouco mais sobre 0 perfil $e$ as expectativas dos colaboradores, ao longo do curso, são propostas as seguintes questões, em formato de enquete: "você já fez algum curso online?"; "qual(is) dispositivo(s) você está utilizando para acessar o curso?"; "como você avalia a importância das informações deste curso para o seu trabalho?"; e "você já conhecia as informações apresentadas no curso?". Fóruns também foram utilizados em todos os capítulos para esclarecer dúvidas eventuais.

A carga horária prevista para a realização do curso é de oito horas, porém seu desenho e a forma como é disponibilizado permite ao colaborador navegar na ordem desejada pelos capítulos. Por se tratar de um conteúdo mais instrutivo, priorizou-se, dentro das limitações da ferramenta utilizada para a produção, recursos visualmente didáticos e lúdicos, como diagramas animados e simulação da dinâmica de jogos, como tabuleiro no capítulo de $\mathrm{RH}$ e quebra-cabeça no de Segurança do Trabalho (figura 7). Neste capítulo, por se tratar de um assunto que envolve a segurança e a vida do colaborador, optou-se por uma abordagem mais emocional, com depoimentos de quem perdeu pessoas queridas em acidentes de trabalho. $O$ objetivo é, portanto, explorar conteúdos mais criativos, gerando proximidade com o colaborador e divulgando a cultura corporativa. 
Figura 7 - Exemplos de telas do curso Integração

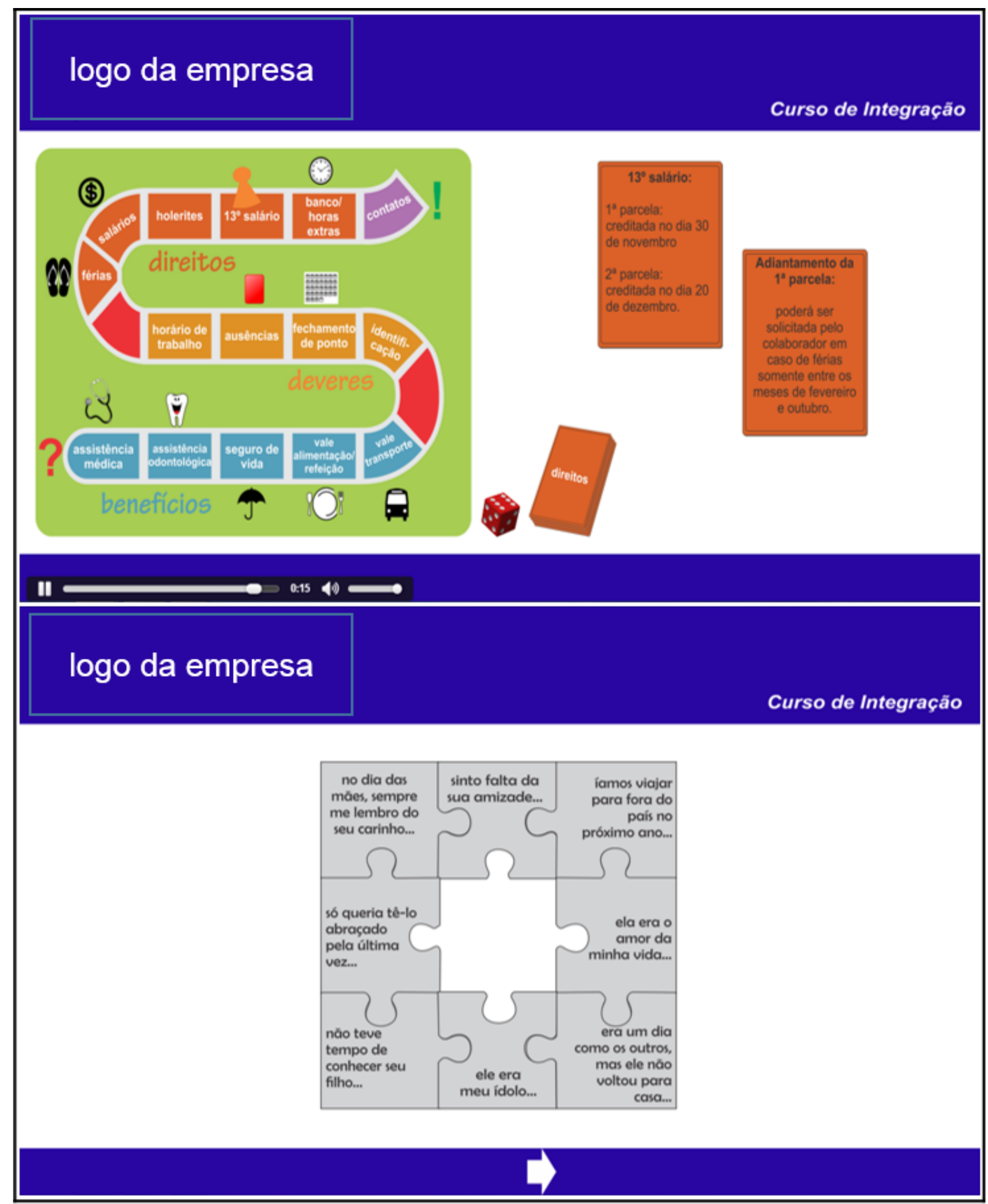

Fonte: Autora.

Ao encerrar o curso, preenchendo a avaliação de reação, o acesso é mantido, facilitando consultas posteriores ao conteúdo por parte dos colaboradores. A divulgação foi feita pelos gestores, através de e-mails enviados aos colaboradores recém-contratados. Durante os meses de dezembro de 2015 e janeiro de 2016, 334 colaboradores concluíram o curso Integração. 
Os resultados da avaliação de reação do curso foram divididos em sete categorias: conteúdo, metodologia, organização, comunicação, recursos educacionais, avaliação geral e perfil de aprendizagem. Em relação ao conteúdo, foram apresentadas quatro afirmações a serem assinaladas com base em uma escala de "concordo totalmente" a "discordo totalmente".

Conforme gráfico 20 , observa-se que a avaliação foi positiva em relação à ampliação do conhecimento sobre o conteúdo e ao atendimento às expectativas dos colaboradores, contando com aplicação prática e abordagem adequada às atividades do dia a dia. Quanto à metodologia, avaliou-se a sequência de apresentação do conteúdo que, para 95,5\% dos colaboradores, foi adequada.

\section{Gráfico 20 - Avaliação do conteúdo do curso Integração}

Meu conhecimento sobre o conteúdo foi ampliado após o treinamento

O conteúdo atendeu às minhas expectativas

O conteúdo tem aplicação prática

O conteúdo foi abordado com a profundidade necessária a minhas atividades

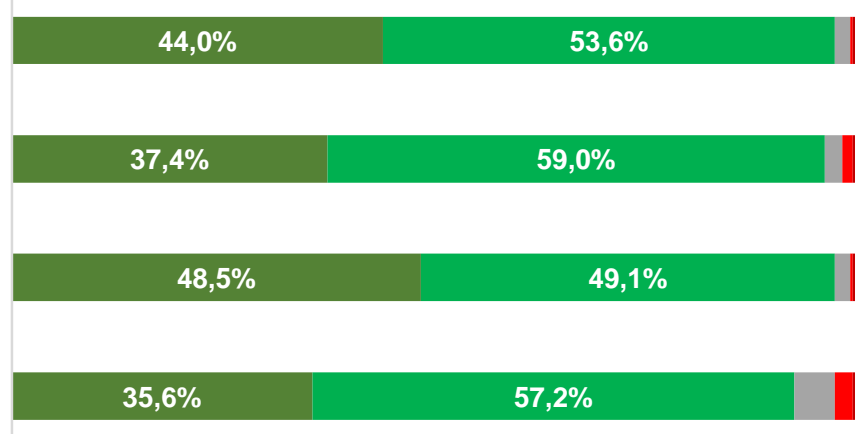

$35,6 \%$ $57,2 \%$

m concordo totalmente $\quad$ concordo $\square$ indiferente $\quad$ discordo $\square$ discordo totalmente Fonte: Autora.

As questões sobre a organização do curso envolveram avaliação do ambiente Moodle, das instruções para acessar a plataforma e da interação por meio do fórum. A avaliação foi positiva, conforme verifica-se no gráfico 21. Sobre a comunicação, questionou-se sobre a clareza e objetividade na explicação do conteúdo, com concordância de $98 \%$ dos respondentes. 
Gráfico 21 - Avaliação da organização do curso Integração

O ambiente Moodle foi adequado

As instruções para acessar o Moodle foram adequadas

A interação via fórum complementou o processo de aprendizagem do conteúdo

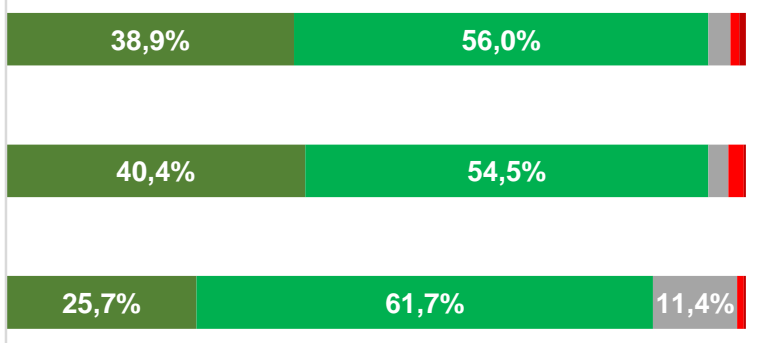

m concordo totalmente $\quad$ concordo $\quad$ indiferente discordo discordo totalmente Fonte: Autora.

Os recursos educacionais também foram avaliados positivamente (gráfico 22). $92,5 \%$ dos respondentes concordam que recursos como vídeos, textos, atividades e animações são ricos para a compreensão do conteúdo; e 98,2\% confirmam que esses permitiram observar a importância dos procedimentos no dia a dia de trabalho.

\section{Gráfico 22 - Avaliação dos recursos educacionais do curso Integração}

Os recursos educacionais utilizados (vídeos, textos, atividades e animações) foram ricos para a compreensão do conteúdo

Os recursos utilizados permitiram-me "visualizar" a importância dos procedimentos no dia a dia de trabalho

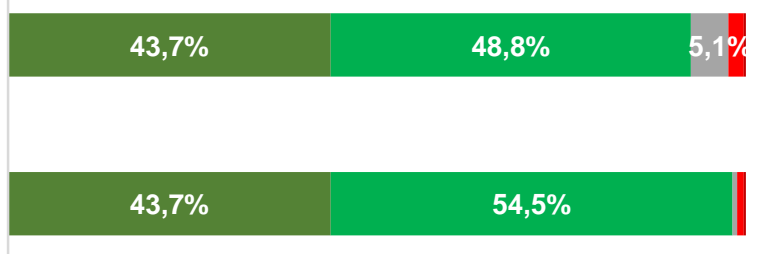

m concordo totalmente $\quad$ concordo $\quad$ indiferente discordo $\quad$ discordo totalmente Fonte: Autora.

$\mathrm{Na}$ avaliação geral do curso, mais de $90 \%$ dos respondentes concordam que o treinamento os capacitou a executar atividades diárias de sua função e a utilizar os canais de comunicação e os equipamentos de trabalho; foi importante para conhecer a cultura corporativa e o perfil dos colaboradores; e disponibilizou contatos para esclarecimento de possíveis dúvidas (gráfico 23). 
Gráfico 23 - Avaliação geral do curso Integração

Após o treinamento, sinto-me apto a executar as atividades diárias da minha função

O treinamento foi importante para conhecer a cultura corporativa e o perfil dos funcionários

Em caso de dúvidas no trabalho, sei a que/quem recorrer para esclarecê-las

Após o treinamento, estou apto a utilizar os canais de comunicação e os equipamentos
$42,2 \%$
$47,3 \%$
$49,4 \%$

$48,2 \%$

$48,5 \%$

$38,9 \%$

- concordo totalmente $\square$ concordo $\square$ indiferente $\quad$ discordo $\quad$ discordo totalmente Fonte: Autora.

Para complementar a pesquisa sobre inteligências múltiplas, foram inseridas, na avaliação de reação, afirmações sobre formatos de recursos educacionais, interações, modalidade de cursos, entre outras, a serem avaliadas pelos colaboradores. Os resultados sinalizam as preferências dos respondentes e corroboram as inteligências predominantes: lógico-matemática, interpessoal e musical (gráfico 24).

Em relação ao deslocamento físico para participar de cursos presenciais, porém, $15,3 \%$ discordam que represente uma barreira e 18,9\% são indiferentes quanto a isso. Quanto à modalidade $\mathrm{EAD}, 93,7 \%$ concordaram que têm facilidade com este formato; $99,1 \%$ consideram ferramentas online importantes para consultar conteúdos a qualquer momento; e 97,3\% têm interesse de participar de outros cursos online. 
Gráfico 24 - Avaliação do perfil de aprendizagem - curso Integração

Vídeos, imagens, animações e gráficos auxiliam-me a compreender melhor o conteúdo Textos e exercícios individuais são importantes para meu aprendizado

Recursos sonoros ajudam a fixar conteúdos Aprendo mais quando posso interagir e discutir com colegas e instrutores

Considero importantes os cursos a distância e tenho facilidade com este formato

O uso de recursos educacionais, como os jogos, torna os treinamentos mais interessantes

Considero importantes ferramentas online para consultar conteúdos a qualquer momento

Considero o deslocamento físico uma barreira para participar de cursos presenciais

Considero importante a interação com colegas para solucionar problemas e trocar experiências

Tenho interesse em participar de outros cursos online realizados pela empresa

Tenho interesse em fazer novos cursos que tornem meu currículo mais interessante

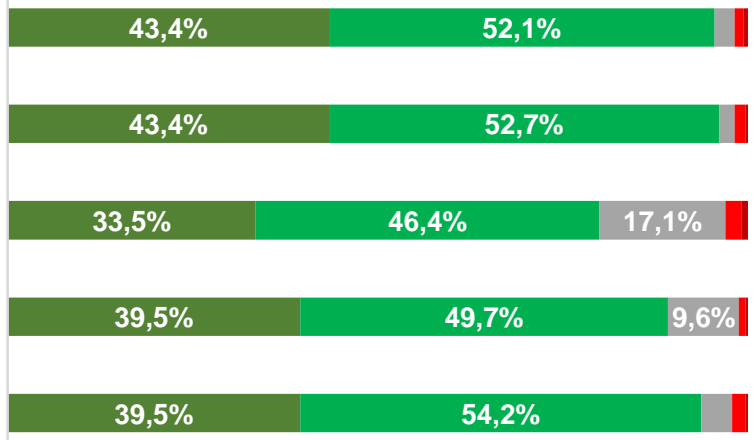

$\begin{array}{lll}33,8 \% & 53,3 \% & 10,8 \%\end{array}$

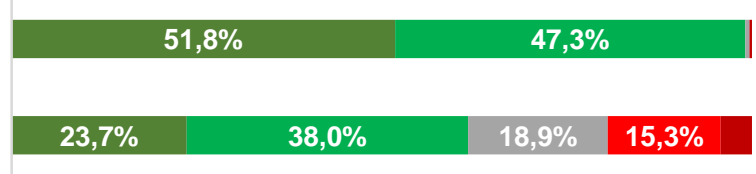
$61,1 \%$ $37,4 \%$

$59,6 \%$ $37,7 \%$

\section{$74,0 \%$} $25,1 \%$

m concordo totalmente $\square$ concordo $\square$ indiferente $\quad$ discordo $\square$ discordo totalmente Fonte: Autora.

No espaço dedicado a comentários e sugestões, 145 colaboradores, ou seja, $43 \%$ do total, escreveram 168 mensagens. Essas foram analisadas e organizadas em cinco categorias: elogios, conteúdo, EAD/Moodle, sugestões de cursos e melhorias (gráfico 25).

Gráfico 25 - Categorias das respostas qualitativas da avaliação de reação do curso Integração

Elogios

$36,3 \%$

Conteúdo

$21,4 \%$

EAD/Moodle

$16,1 \%$

Sugestões cursos

$14,9 \%$

Melhorias

$11,3 \%$

Fonte: Autora. 
Os comentários mais relevantes estão disponíveis no apêndice M. Entre esses, destacam-se: "acredito que a empresa esteja focada na qualidade de seu colaborador e, com isso, quem ganha somos nós, por sermos profissionais qualificados e atualizados, em um mercado de trabalho cada vez mais competitivo"; "dá uma segurança começar a trabalhar sabendo como a empresa funciona"; "curso claro, explicações fáceis e de aprendizado rápido"; "essa é uma excelente forma de estarmos integrados com informações importantes, de forma econômica e no conforto do local onde escolhemos para acompanhar o treinamento"; "poderia ser um pouco mais interativo e intuitivo"; "o Moodle apresenta bom conteúdo, porém acredito que ainda há necessidade de uma atenção maior para a apresentação do mesmo nos quesitos aparência, sequência, rapidez e controle em relação ao acesso".

Além dos comentários da avaliação de reação, um dos colaboradores enviou um e-mail para os gestores do departamento de treinamento, com a seguinte mensagem: "Parabenizo a todos os envolvidos no desenvolvimento desta ferramenta. Agora tenho que terminar de assistir as aulas de integração com 16 anos de atraso". Entre críticas e sugestões, a avaliação de reação cumpre seu papel, abrindo espaço para ouvir os colaboradores e possibilitando coletar informações essenciais ao planejamento das próximas ações de EC.

\subsubsection{Curso TCP/IP}

Para o curso voltado ao setor técnico, foi escolhido o tema TCP/IP, protocolo da indústria de rede que especifica mecanismos de formatação, endereçamento e roteamento, garantindo o envio das mensagens ao receptor. $O$ conhecimento sobre TCP/IP é utilizado com frequência pelos técnicos da empresa estudada na resolução de ocorrências, porém surgem várias dúvidas no dia a dia. O curso é oferecido presencialmente no treinamento introdutório, aos novos colaboradores, porém com carga horária reduzida.

Para a estruturação do conteúdo para o curso online, os gestores do departamento de treinamento ampliaram a abordagem, incluindo assuntos correlacionados ao tema principal, como é o caso da conversão binário/decimal e decimal/binário. Desse modo, a versão final do curso conta com carga horária de seis horas e cronograma de três semanas para realização, considerando que o grupo de controle utilizou o horário de trabalho para fazê-lo. Ao todo, são quatorze capítulos, 
com exercícios e fóruns. Neste curso, há também três enquetes: "você já fez algum curso online?"; "com que frequência você utiliza informações sobre TCP/IP?", e "qual(is) dispositivo(s) você está utilizando para acessar o curso?".

Em relação aos objetivos de aprendizagem, ao final do curso, o colaborador deve estar apto a: calcular a faixa de endereços e o número de hosts de uma rede; converter números decimais em binários; estabelecer a comunicação entre os equipamentos para solucionar ocorrências no tempo estimado; diagnosticar problemas técnicos sem demandar acesso remoto; e executar testes para garantir o correto funcionamento da rede.

Neste curso, também se priorizou a apresentação das informações de modo mais didático e graficamente mais intuitivo (figura 8). As limitações da ferramenta utilizada para sua produção, porém, não permitiram produzir todas as animações previstas. A sequência dos capítulos foi desenvolvida de forma linear, considerando a necessidade de elaboração gradativa do conhecimento. Desse modo, o colaborador só avança de um capítulo a outro após finalizá-lo e concluir os exercícios correspondentes. Ao finalizar todo o curso, porém, ele passa a ter acesso a todos os capítulos, podendo consultá-los sempre que necessário e na ordem desejada.

A fim de motivar e orientar o estudo do tema, foi realizado um chat síncrono para a abertura do curso, reunindo os gestores do departamento de treinamento e os colaboradores do grupo de controle. E-mails foram disparados periodicamente, lembrando o colaborador sobre a necessidade de seguir o cronograma, a fim de manter uma sequência adequada de estudo. Ao final do curso, os alunos realizaram a avaliação de reação e a avaliação conceitual.

O curso foi realizado por três grupos de controle, entre os meses de outubro de 2015 e janeiro de 2016, totalizando 73 colaboradores que finalizaram todas as atividades previstas. Participaram dos grupos colaboradores indicados por seus coordenadores. Após a primeira turma, que se encerrou com dez colaboradores, foi realizada uma entrevista individual e online com cada um dos interessados (sete colaboradores), a fim de conhecer a receptividade do curso. As sugestões, que não se relacionavam às limitações da ferramenta de produção, foram implementadas para a segunda e terceira turmas, como a ampliação da quantidade de exercícios e a sinalização mais clara em relação à finalização de cada capítulo. 
Figura 8 - Exemplos de telas do curso TCP/IP

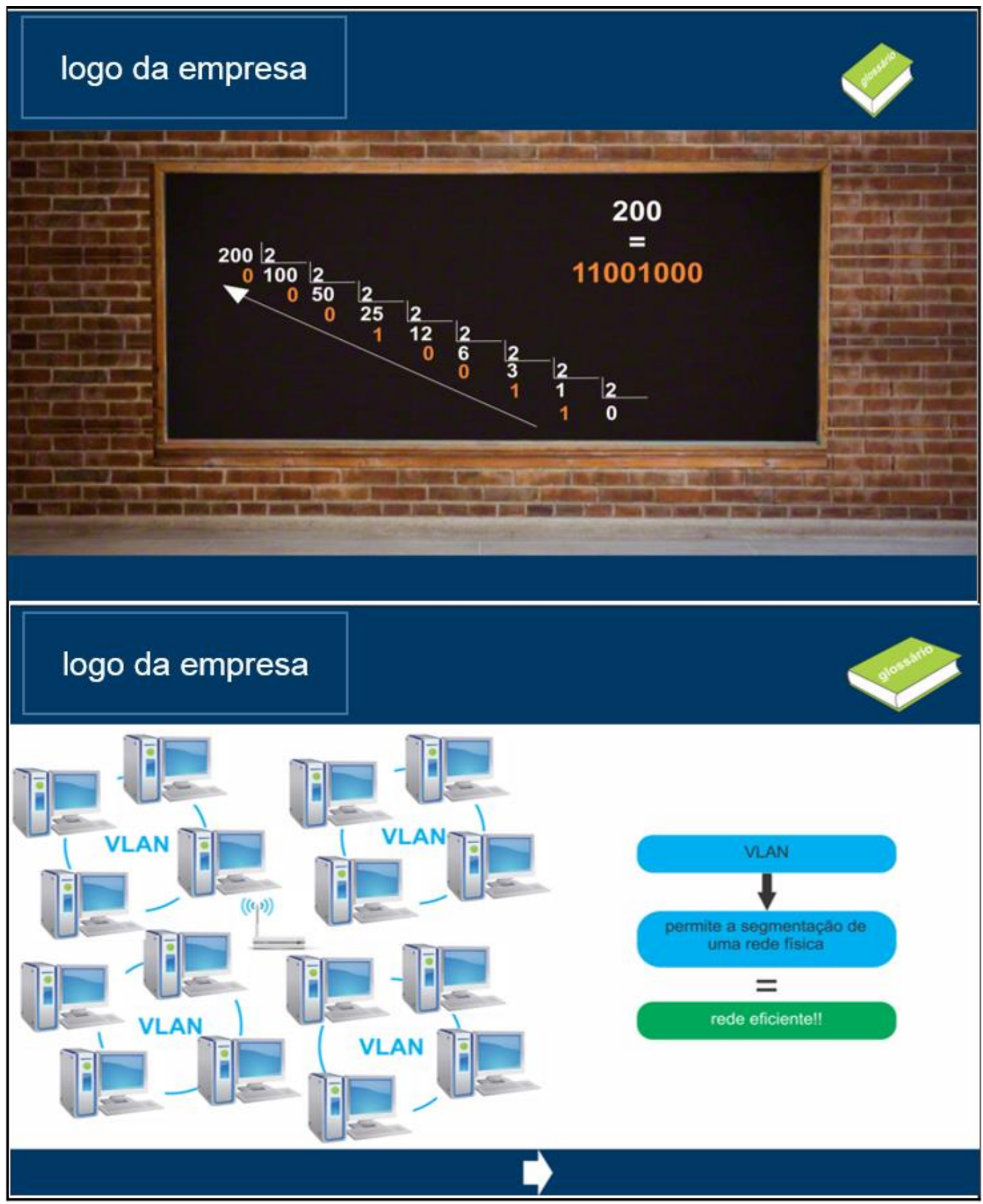

Fonte: Autora.

A avaliação de reação contou com as mesmas categorias do formulário aplicado no curso Integração, porém com o acréscimo de algumas questões. De modo geral, a avaliação do conteúdo foi positiva, com a ressalva de que, para $20,5 \%$ dos 
respondentes, o conteúdo não foi abordado com a profundidade necessária às suas atividades (gráfico 26).

\section{Gráfico 26 - Avaliação do conteúdo do curso TCP/IP}

Meu conhecimento sobre o conteúdo foi ampliado após o treinamento

O conteúdo atendeu às minhas expectativas

O conteúdo tem aplicação prática

O conteúdo foi abordado com a profundidade necessária a minhas atividades

\section{$27,4 \%$}

\begin{tabular}{|c|c|c|c|}
\hline $42,5 \%$ & & $47,9 \%$ & $9,6 \%$ \\
\hline $19,2 \%$ & $50,7 \%$ & $9,6 \%$ & $20,5 \%$ \\
\hline
\end{tabular}

घ concordo totalmente $\quad$ concordo $\square$ indiferente $\square$ discordo

Fonte: Autora.

A metodologia utilizada na apresentação do conteúdo, os exercícios e as atividades práticas do curso também foram avaliados positivamente por mais de $78 \%$ dos colaboradores. Veja gráfico 27.

\section{Gráfico 27 - Avaliação da metodologia do curso TCP/IP}

A sequência de apresentação do conteúdo foi adequada

$15,1 \% \quad 63,0 \% \quad 9,6 \% 12,3 \%$

Os exercícios ajudaram a fixar o conteúdo

As atividades práticas foram valiosas para a compreender o conteúdo e sua aplicabilidade

$\begin{array}{lll}27,4 \% & 53,4 \% & 11,0 \% 8,2 \%\end{array}$

\begin{tabular}{l|ll}
$17,8 \%$ & $60,3 \%$ & $15,1 \% \quad 6,8^{\circ}$
\end{tabular}

$$
\square \text { concordo totalmente } \square \text { concordo } \square \text { indiferente } \square \text { discordo }
$$

Fonte: Autora.

Em relação à organização do curso $\mathrm{TCP} / \mathrm{IP}$, todos os itens foram avaliados positivamente por mais de $65 \%$ dos respondentes, conforme apresenta o gráfico 28 . 


\section{Gráfico 28 - Avaliação da organização do curso TCP/IP}

O ambiente Moodle foi adequado

As instruções para acessar o Moodle foram adequadas

A mediação do tutor foi adequada

A interação via fórum complementou o processo de aprendizagem do conteúdo

$\begin{array}{lll}21,9 \% & 65,8 \% & 8,2 \%\end{array}$

$35,6 \%$

$60,3 \%$

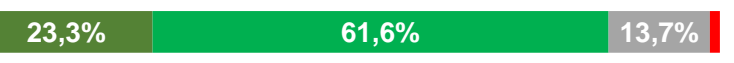

$\begin{array}{lll}13,7 \% & 54,8 \% & 28,8 \%\end{array}$

шconcordo totalmente $\quad$ concordo $\square$ indiferente $\quad$ discordo

Fonte: Autora.

Os recursos comunicacionais do curso também foram avaliados positivamente, com concordância da maioria sobre a clareza e a objetividade na explicação do conteúdo, a disposição do tutor e os momentos de interação (gráfico 29).

Gráfico 29 - Avaliação da comunicação do curso TCP/IP

A explicação do conteúdo foi clara e objetiva

$20,6 \%$ $53,4 \%$

$8,2 \% \quad 17,8 \%$

O tutor foi atencioso e prestativo

O tutor mostrou-se disposto a esclarecer dúvidas

Houve momentos para interação com os colegas e com o tutor

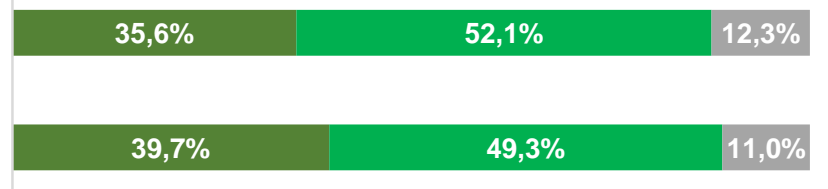

$12,3 \%$ $50,7 \%$ $30,1 \% \quad 5,5 \%$

a concordo totalmente $\square$ concordo $\square$ indiferente $\quad$ discordo discordo totalmente Fonte: Autora.

Os recursos educacionais utilizados foram considerados ricos para a compreensão do conteúdo por $74 \%$ dos respondentes e, para $82,2 \%$, esses permitiram perceber a importância dos procedimentos do dia a dia de trabalho (gráfico 30). 
Gráfico 30 - Avaliação dos recursos educacionais do curso TCP/IP

Os recursos educacionais utilizados (vídeos,

textos, atividades e animações) foram ricos para a compreensão do conteúdo

Os recursos utilizados permitiram-me "visualizar" a importância dos procedimentos no dia a dia de trabalho

\begin{tabular}{lll}
$24,7 \%$ & $49,3 \%$ & $12,3 \%$ \\
\hline & $13,7 \%$
\end{tabular}

$24,7 \%$ $57,5 \%$ $15,1 \%$

$$
\text { - concordo totalmente } \quad \text { concordo } \square \text { indiferente } \quad \text { discordo }
$$

Fonte: Autora.

$\mathrm{Na}$ avaliação geral do curso, $75,4 \%$ sentem-se aptos a executar suas atividades diárias após o treinamento; $75,3 \%$ consideram o treinamento importante para conhecer a cultura corporativa e o perfil dos colaboradores; $90,4 \%$ sabem a que/quem recorrer em caso de dúvidas; e 86,3\% estão aptos a utilizar os canais de comunicação e os equipamentos da empresa. Veja gráfico 31 .

\section{Gráfico 31 - Avaliação geral do curso TCP/IP}

Após o treinamento, sinto-me apto a executar as atividades diárias da minha função

O treinamento foi importante para conhecer a cultura corporativa e o perfil dos funcionários

Em caso de dúvidas no trabalho, sei a que/quem recorrer para esclarecê-las

Após o treinamento, estou apto a utilizar os canais de comunicação e os equipamentos

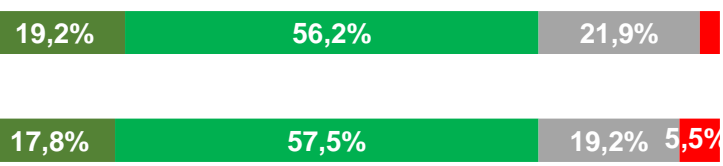

$31,5 \%$ $58,9 \%$ $9,6 \%$
$24,7 \%$ $61,6 \%$

Fonte: Autora.

A avaliação das preferências por formatos de recursos educacionais e modalidades apresenta resultados muito semelhantes em relação ao curso Integração (gráfico 32). Há avaliação positiva dos recursos utilizados e da modalidade online, da mesma forma em que o deslocamento físico não representa uma barreira para um número significativo de respondentes: $30,1 \%$. 


\section{Gráfico 32 - Avaliação do perfil de aprendizagem - curso TCP/IP}

Vídeos, imagens, animações e gráficos auxiliam-me a compreender melhor o conteúdo

Textos e exercícios individuais são importantes para meu aprendizado

Recursos sonoros ajudam a fixar conteúdos

Aprendo mais quando posso interagir e discutir com colegas e instrutores

Considero importantes os cursos a distância e tenho facilidade com este formato

O uso de recursos educacionais, como os jogos, torna os treinamentos mais interessantes

Considero importantes ferramentas online para consultar conteúdos a qualquer momento

Considero o deslocamento físico uma barreira para participar de cursos presenciais

Considero importante a interação com colegas para solucionar problemas e trocar experiências

Tenho interesse em participar de outros cursos online realizados pela empresa

Tenho interesse em fazer novos cursos que tornem meu currículo mais interessante
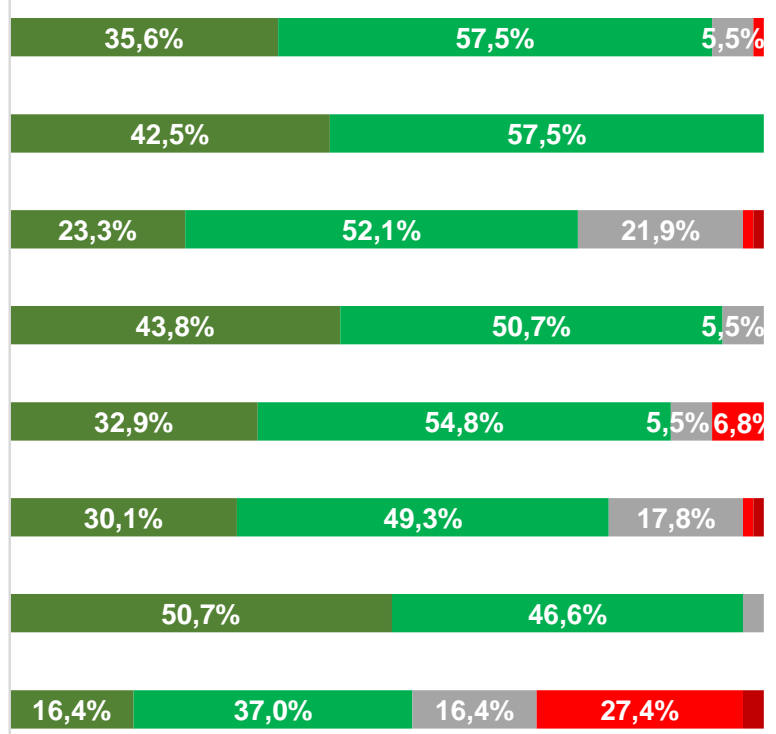

$63,0 \%$ $32,9 \%$
$31,5 \%$

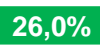

m concordo totalmente $\square$ concordo $\square$ indiferente discordo $\quad$ discordo totalmente

Fonte: Autora.

Os resultados qualitativos da avaliação de reação consistem em 47 comentários feitos por 30 respondentes, ou seja, $41 \%$ do total de concluintes do curso. Esses foram estruturados em cinco categorias de análise: elogios, conteúdo, recursos, aprofundamento e equipe (veja gráfico 33), sendo que as duas primeiras também foram verificadas no curso Integração.

Gráfico 33 - Categorias das respostas qualitativas da avaliação de reação do curso $\mathrm{TCP} / \mathrm{IP}$

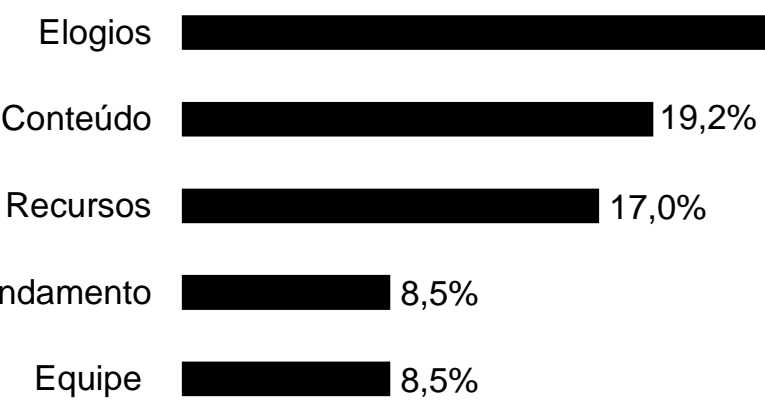

Fonte: Autora. 
Os comentários mais relevantes estão disponíveis no apêndice M. Entre esses, destacam-se: "gostaria de parabenizá-los pela iniciativa dos cursos online, pela importância do conteúdo no dia a dia, pela reciclagem e pelos conhecimentos adquiridos"; "deveriam haver mais animações para interações com os usuários, acho que isso facilitaria o entendimento do conteúdo"; "alguns assuntos foram abordados de forma simples e cobrados nos testes de forma complexa"; "agradeço aos profissionais envolvidos na construção do curso, desde abordagem, apresentação, conteúdo e fórum de dúvidas". Todos os comentários auxiliam na análise sobre a receptividade da prova de conceito e orientam o planejamento das próximas ações de EC.

A avaliação conceitual, realizada por meio de dez questões disponibilizadas ao final do curso, também apresenta resultado satisfatório quando comparado com as avaliações anteriores. De acordo com os gestores do departamento de treinamento, nos cursos presenciais, a avaliação do conteúdo sobre TCP/IP tem sido realizada por meio de uma ou duas questões em um questionário que aborda assuntos do curso introdutório. No último curso presencial, anterior à aplicação da prova de conceito, nenhum dos participantes conseguiu responder corretamente à questão sobre TCP/IP. Na avaliação disponibilizada no Moodle para aqueles que finalizaram todas as atividades previstas (71 colaboradores), $65 \%$ obtiveram nota superior a 5,1 . No gráfico 34 , constam as porcentagens de respondentes e suas respectivas notas. Analisando o perfil de acesso no Moodle, observa que os colaboradores que obtiveram as maiores notas dedicaram um tempo superior à avaliação em relação aos que não alcançaram bom desempenho.

Gráfico 34 - Média final da avaliação conceitual do curso TCP/IP

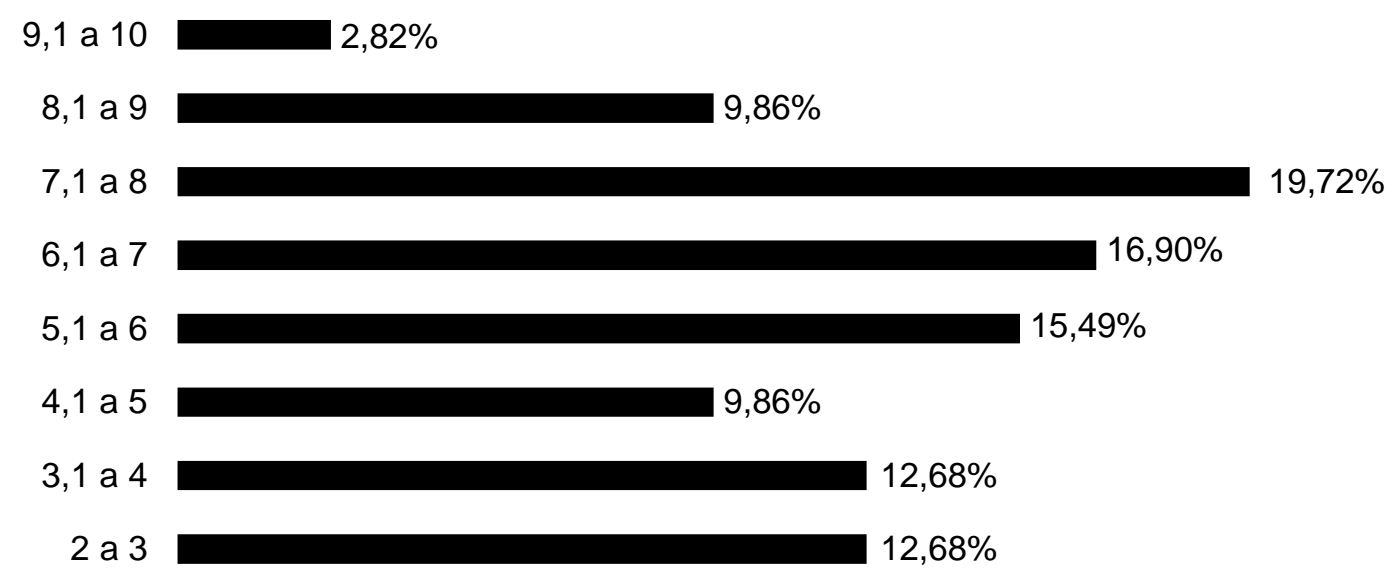

Fonte: Autora. 
As respostas às enquetes também auxiliam no entendimento do perfil dos colaboradores e no planejamento de novas ações. Ao serem questionados sobre a realização prévia de cursos online, $76 \%$ dos respondentes de ambos os cursos (Integração e TCP/IP), 405 no total, responderam positivamente. Em relação aos dispositivos utilizados para acessar os cursos, destacaram-se: notebook, computador de mesa e smartphone (gráfico 35).

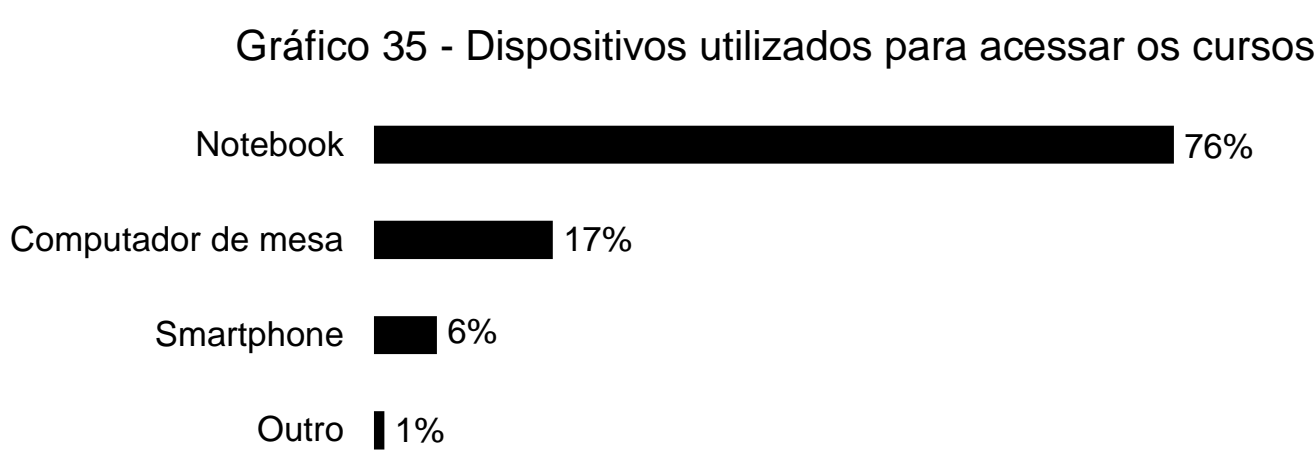

Fonte: Autora.

Quanto à frequência com que utilizam as informações sobre TCP/IP, observa-se que a maioria dos respondentes deste curso respondeu "todos os dias" (gráfico 36), dado que ressalta a importância da abordagem do tema para o dia a dia de trabalho.

Gráfico 36 - Frequência com que utiliza informações sobre TCP/IP

Todos os dias $48,4 \%$

De 1 a 3 vezes por semana $21,9 \%$

De 1 a 3 vezes por mês $10,2 \%$

De 6 a 11 vezes por ano $3,9 \%$

Raramente $13,3 \%$

Nunca $2,3 \%$

Fonte: Autora.

\subsubsection{Jogo}

Considerando a inteligência lógico-matemática, predominante na empresa estudada, propôs-se uma prova de conceito que envolve a solução de problemas em um formato de jogo sério. $O$ jogo sério ou serious game consiste em uma área que se 
ocupa em aplicar a tecnologia dos games no desenvolvimento de aplicações sem fins de entretenimento (TORI, 2010). Desenvolveu-se uma solução que utiliza a dinâmica de jogos para testar conhecimento, no caso, o conteúdo ministrado no curso online TCP/IP. De acordo com Kapp, Blair e Mesch (2003), os jogos de teste são utilizados quando o aluno precisa saber uma determinada informação para ser bem-sucedido.

Para estruturar o conteúdo do jogo, foi desenvolvido um storytelling, que, segundo Cogo (2013), "é uma lógica de estruturação de pensamentos e um formato de organização e difusão da narrativa, por suportes baseados nas experiências de vida próprias ou absorvidas de um interagente [...]". Foi solicitado aos gestores do departamento de treinamentos um exemplo de ocorrência, com descrição de todo o processo de atendimento, desde a comunicação com o colaborador mais próximo ao site até a resolução do problema.

Esta ocorrência foi contextualizada em uma missão que deve ser cumprida pelo colaborador não apenas para atender o cliente, mas, também, para permitir o acesso $3 G$ a seus amigos que desejam participar de uma promoção online durante um jogo de futebol. Os principais objetivos do jogo são: testar o conhecimento do colaborador sobre TCP/IP; instruí-lo quanto ao processo correto de atendimento de uma ocorrência; e promover sua percepção quanto à importância de seu trabalho para a sociedade e, de modo especial, para os amigos mais próximos. A escolha do tema futebol e amigos deve-se ao fato de $87 \%$ dos colaboradores da empresa serem do sexo masculino.

No início do jogo, o colaborador recebe uma chamada telefônica, com descrição da ocorrência a ser atendida. Em seguida, por meio de uma mensagem de texto, seus amigos o convidam a participar de uma promoção para a qual devem postar uma foto feita em campo, durante o jogo (figura 9). Quem postar a melhor foto entre amigos irá visitar o vestiário de seu time ao final da partida. Após receber a ocorrência e a mensagem de texto dos amigos, o colaborador se depara com questões relacionadas aos processos de atendimento do evento (figura 10). 
Figura 9 - Tela de abertura e de apresentação do desafio do jogo

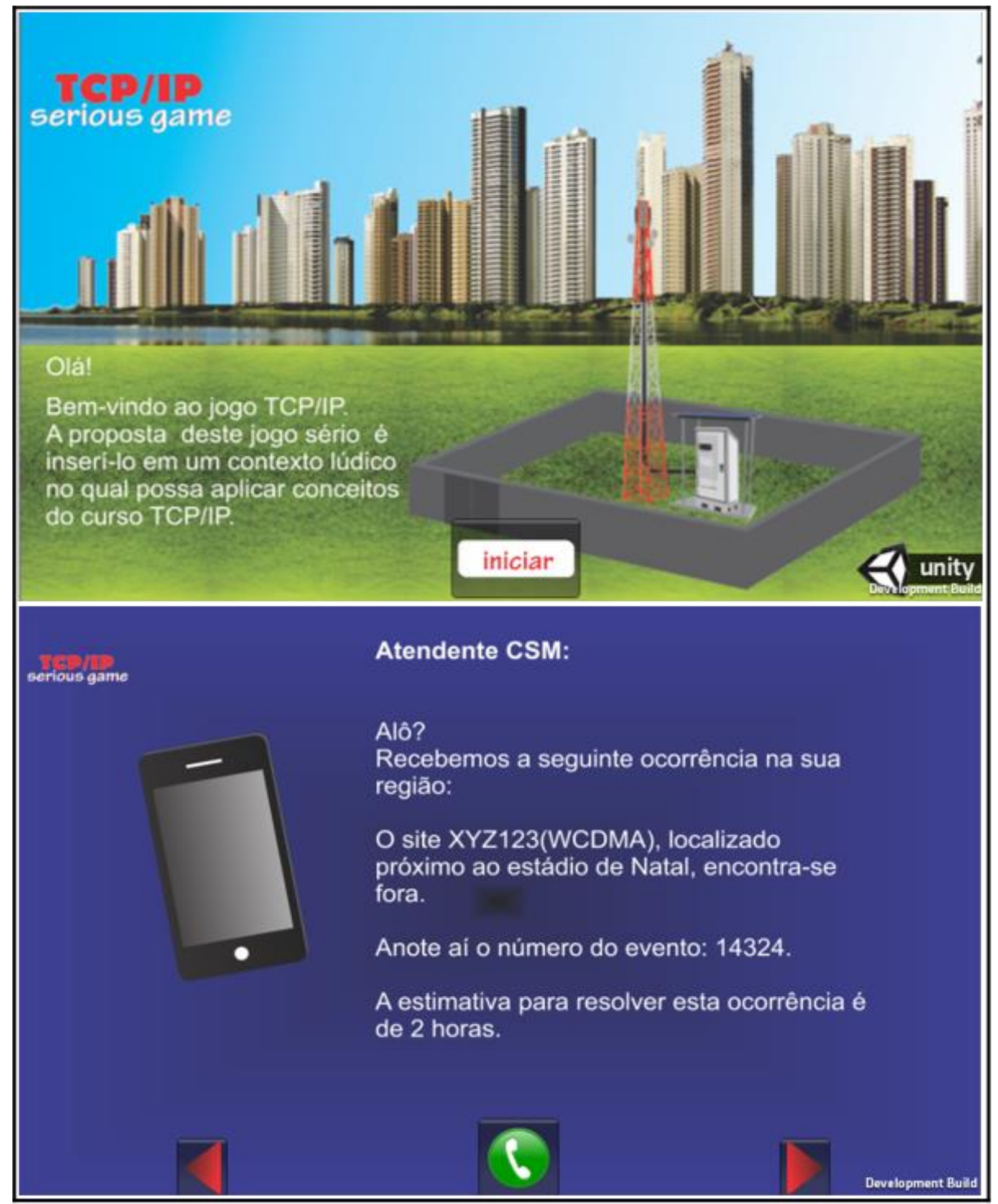

Fonte: Autora. 
Figura 10 - Exemplos de questões do jogo TCP/IP

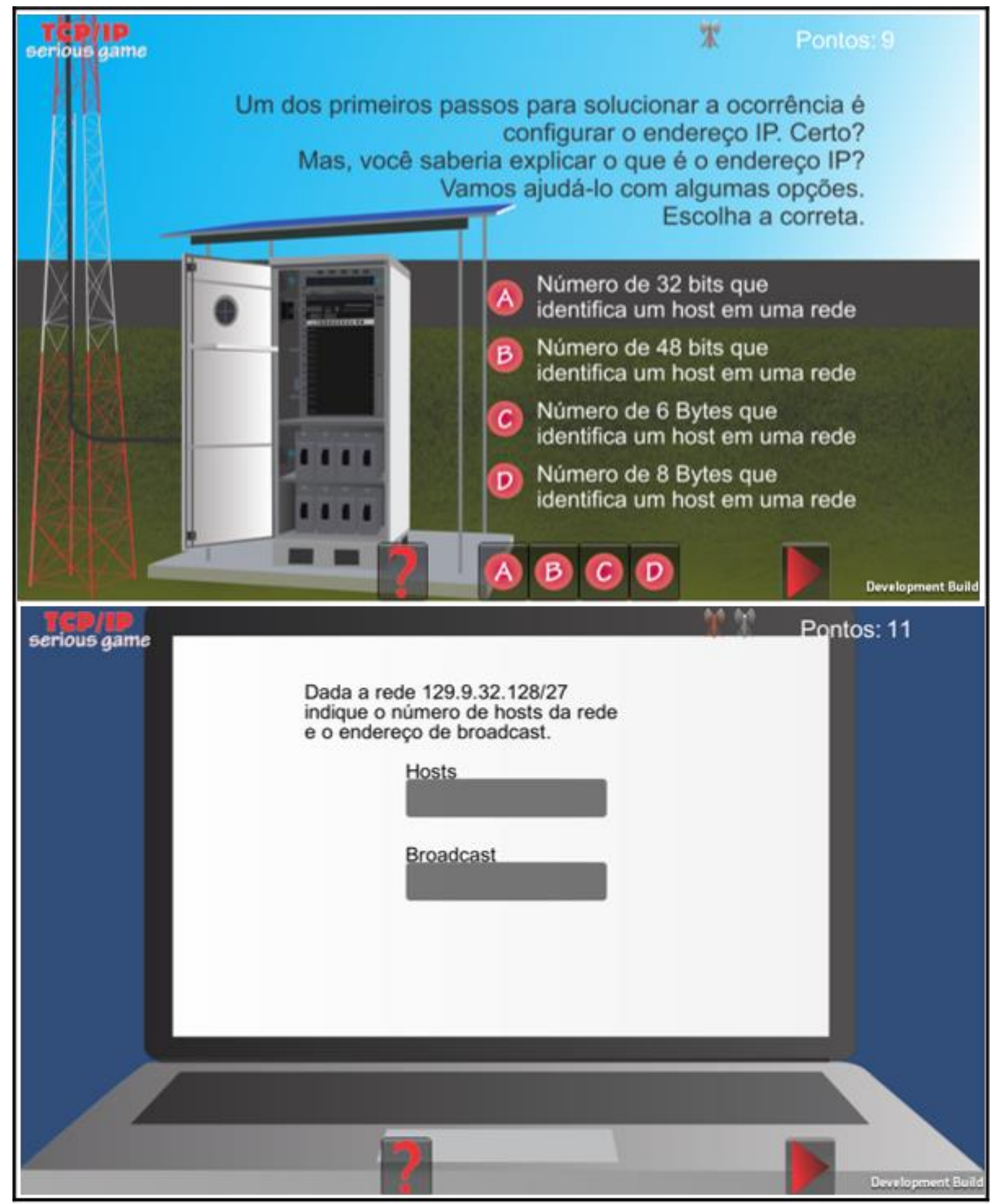

Fonte: Autora.

O jogo conta com três fases: procedimentos, conceitos e operações. Ao responder corretamente às perguntas, o colaborador soma pontos e recebe três torres (bronze, prata e dourada), a cada fase superada. Para auxiliá-lo, todas as questões contam com dicas de ajuda. Desse modo, o colaborador tem a missão de: conseguir 
a torre dourada com o sinal $3 G$ reestabelecido, possibilitando a realização da promoção e a satisfação de seus amigos (figura 11).

A descrição de todos os elementos do jogo (situação, personagens, objetivos, métricas, barreiras e conflitos, controle, cadeia de objetivos, recompensas e fases) está disponível no apêndice $\mathrm{N}$.

Figura 11 - Telas de encerramento do jogo TCP/IP

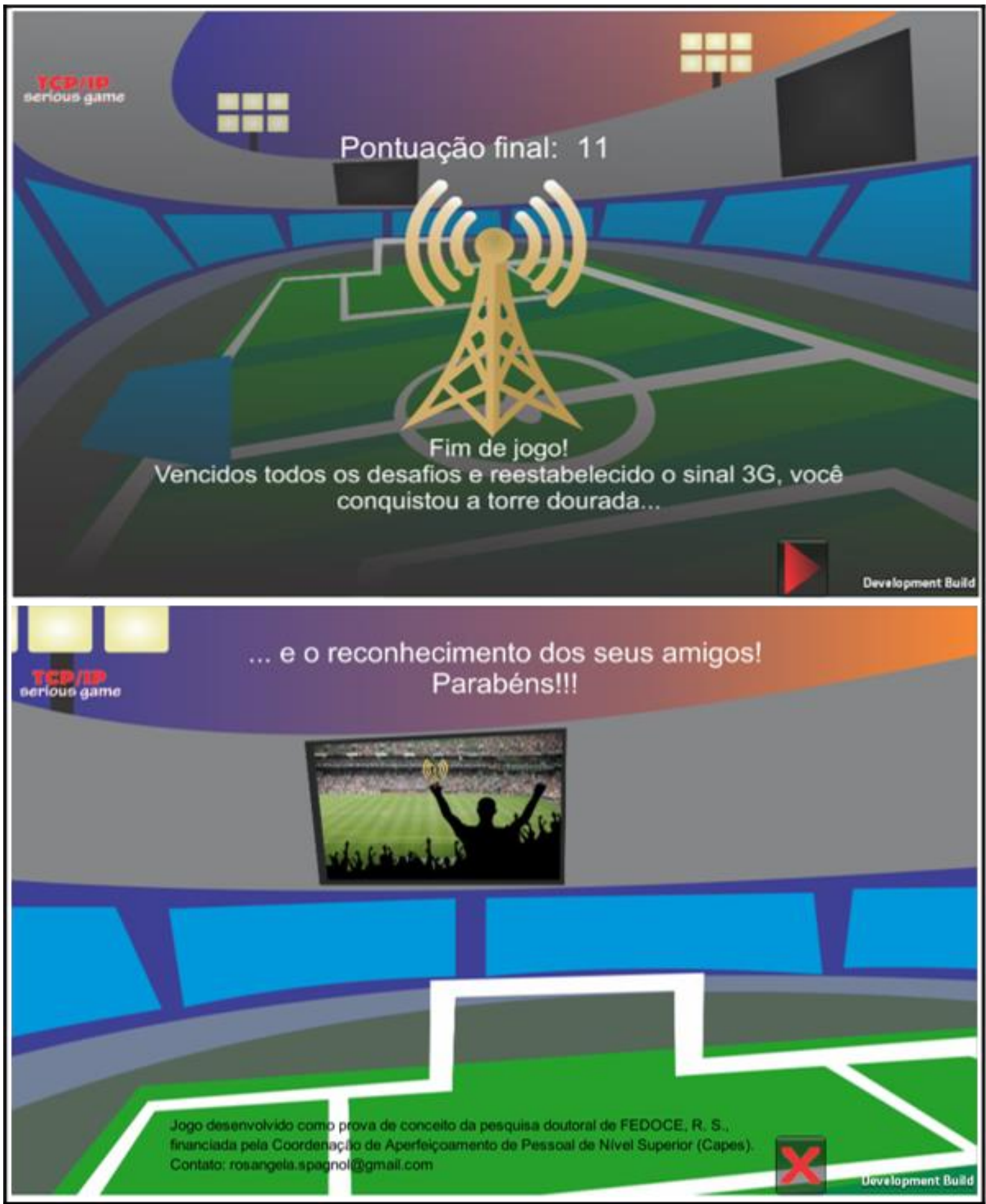

Fonte: Autora. 
A proposta inicial era produzir um jogo no formato de árvore de decisão, aumentando sua dinamicidade. Porém, devido à falta de conhecimento da autora sobre programação de jogos e à finalidade acadêmica das provas de conceito da pesquisa, utilizou-se os recursos mais básicos da versão gratuita da plataforma de desenvolvimento de jogos e experiências interativas Unity ${ }^{1}$.

O jogo foi disponibilizado aos colaboradores que concluíram o curso TCP/IP, sem constituir atividade obrigatória, juntamente com uma avaliação de reação específica (apêndice O). Essa abordou o conteúdo, a usabilidade, a utilidade da ferramenta de ajuda, a motivação para prosseguir no jogo, as instruções, o objetivo final, a abordagem e a demanda por outros jogos. A avaliação dos nove colaboradores respondentes foi positiva, conforme apresenta o gráfico 37. Em relação aos comentários e sugestões, foram feitos três elogios: à iniciativa, à elaboração do jogo e ao método didático, que proporcionou aos colaboradores testar e aprimorar seus conhecimentos.

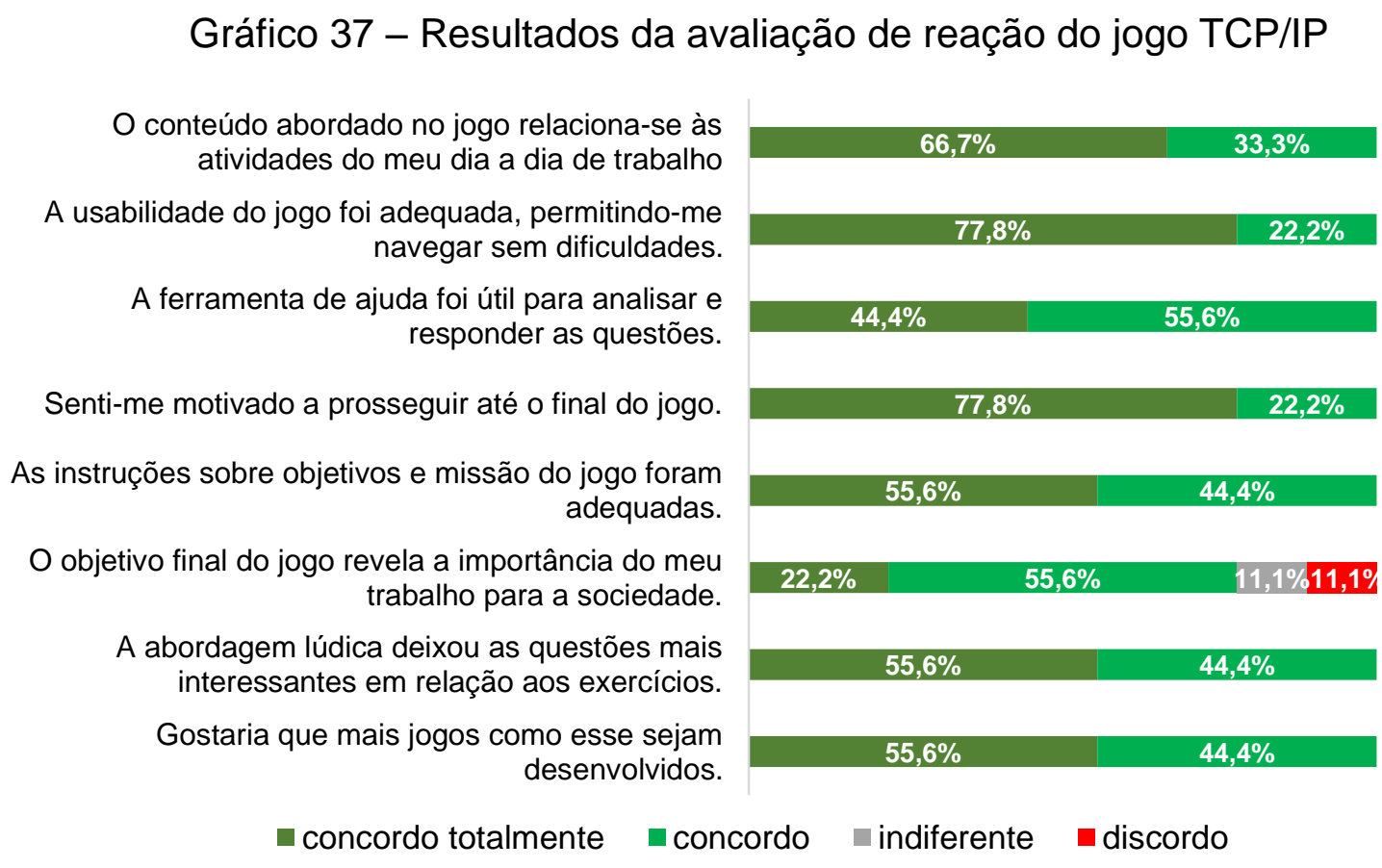

Fonte: Autora.

Além da avaliação, um dos colaboradores, técnico de transmissão, enviou e-mail aos gestores do departamento de treinamento, com a seguinte mensagem: "eu como

\footnotetext{
${ }^{1}$ Outras informações sobre o Unity, disponíveis em: <https://unity3d.com/pt/unity>. Acesso em 28 fev. 2016.
} 
técnico da TX (rede fixa) tive meu primeiro chamado da rede móvel resolvido. Parabéns pelo trabalho bem elaborado e muito interativo, gostaria de participar dos próximos". Desse modo, apesar das limitações no processo de produção do jogo, a implementação desta prova de conceito permite observar a receptividade dos colaboradores em relação aos recursos educacionais mais interativos, sinalizando opções alternativas de abordagem de conteúdo para o programa de EC que integrará o modelo de GC. 


\section{RESULTADOS}

Nesta seção do trabalho, são apresentados os resultados de ambos os estudos realizados, estudo de caso e pesquisa-ação. A partir da análise desses resultados, será apresentado o modelo proposto de GC para o setor de infraestrutura de telecomunicações.

\subsection{GESTÃO DO CONHECIMENTO NO SETOR DE SMVA}

A partir do estudo na integradora, observou-se que essa tem desenvolvido GC e IC a partir de sua relação com os demais segmentos do setor de SMVA. As ORMs também têm investido em GC focando em tendências de marketing e nas necessidades dos usuários finais. As ferramentas de Bl da empresa são apropriadas ao negócio e geram informações básicas, mas essenciais à GC e à IC do setor.

Com o investimento nas três formas de $\mathrm{Cl}$, com destaque para o capital humano e relacional, além da integração, a empresa desenvolve análises sobre perfis de consumidores, mídias com potencial de divulgação e tendências de consumo a partir dessas informações, compondo uma fotografia do mercado de SMVA, que visa a auxiliar a tomada de decisão de seus clientes, agregando valor aos serviços. Além da EC, foi ressaltado o bom relacionamento interno entre as áreas técnicas e de negócios para a estruturação de equipes proativas.

Essa relação colaborativa foi confirmada por três dos quatro representantes das ORMs que participaram da pesquisa. Eles explicaram que há uma troca de informações estratégicas, principalmente relacionada à gestão do negócio, tais como: taxas interessantes para serviços específicos, melhores dias para tarifar o usuário final, experiências sobre serviços previamente criados, entre outras. Entre os tipos de informação disponibilizados pela integradora, foram destacados faturamento e melhoria em serviços (gráfico 38). 
Gráfico 38 - Principais tipos de informação disponibilizadas pela integradora às ORMs

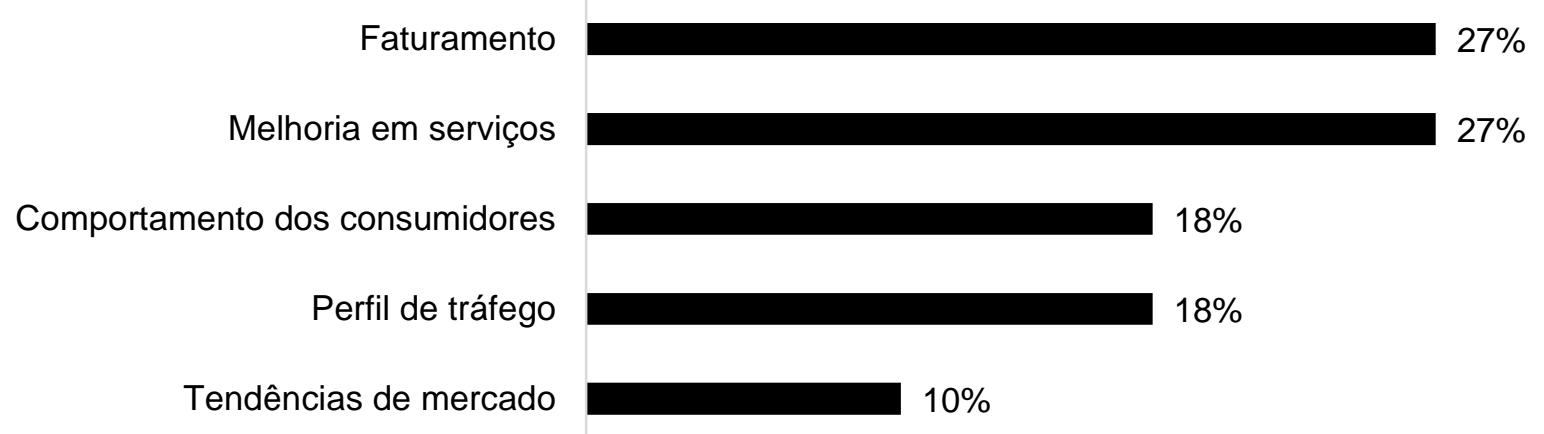

Fonte: Autora.

As ORMs também investem em $\mathrm{Bl}$ e em IC, desenvolvendo pesquisas e contratando consultorias para analisar as tendências de mercado e as necessidades dos consumidores. Os respondentes enumeraram cinco insumos estratégicos, definidos por Fahey (2007), de acordo com as prioridades de suas empresas. São eles: oportunidades de mercado, riscos competitivos, principais vulnerabilidades, pressupostos essenciais e ameaças da concorrência.

Em relação à concorrência, a maioria dos respondentes das ORMs observaram que o impacto dos dispositivos com conexão à Internet e das lojas de aplicativos representam não apenas uma ameaça, mas, também, uma possibilidade para novas parcerias e serviços (gráfico 39). Um dos respondentes destacou que os novos dispositivos representam, ao mesmo tempo, um risco e uma oportunidade para o negócio das ORMs e para as demais empresas do fluxo produtivo de SMVA, de acordo com os serviços oferecidos. Para algumas ORMs que oferecem acesso à Internet, por exemplo, os novos dispositivos representam uma oportunidade. Em relação às lojas de aplicativos, alguns respondentes destacaram que essas implicam queda de SMVA e de usuários finais, ao mesmo tempo em que também expandem as vendas de planos de Internet pelas ORMs. 
Gráfico 39 - O que os dispositivos conectados à Internet e as lojas de aplicativos representam para o negócio das ORMs e para o setor de SMVA brasileiro

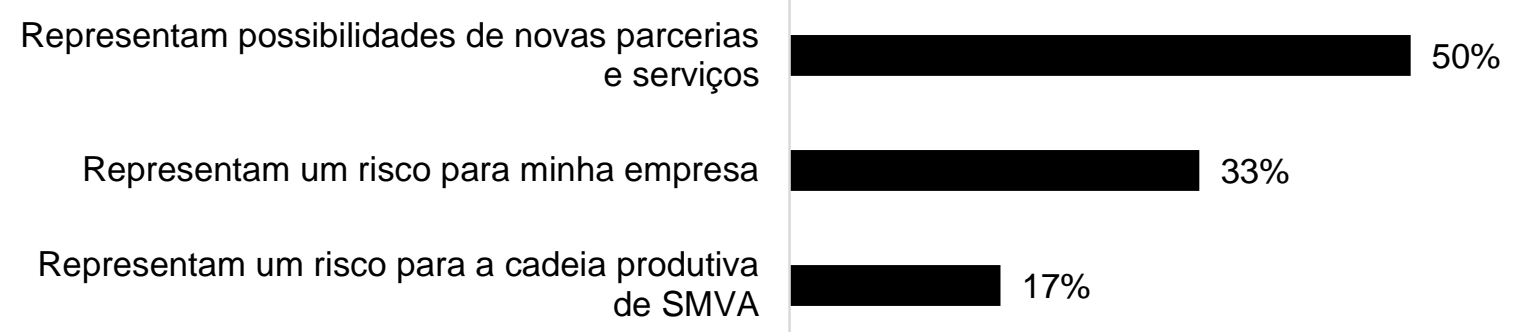

Fonte: Autora.

A competição com as OMVs e OTTPs foi mencionada como um desafio para as ORMs, uma vez que reduz o preço dos serviços de voz e SMS e dos planos de Internet, criando demanda para a ampliação da capacidade da rede. Já em relação à possibilidade de conexão direta entre provedores de conteúdo e ORMs, os respondentes, corroborando Fries (2011), a identificaram como uma ameaça às integradoras. Neste sentido, eles sugeriram que essa invista no fornecimento de oportunidades de negócio e estenda a cadeia de valor para manter-se competitiva.

Observa-se que a integradora está atenta às transformações do mercado. A empresa tem investido na expansão de sua área comercial, no desenvolvimento de equipes técnicas proativas e na realização de pesquisas de mercado, com o objetivo de identificar novas soluções e produtos. Realiza-se monitoramento ambiental contínuo, com foco em oportunidades, buscando melhorias à gestão e aos serviços da empresa e verificando demandas do mercado nacional e tendências do mercado internacional. As ORMs também têm se mostrado atentas à dinâmica do mercado, investindo em pesquisas e consultorias, a fim de observar novas oportunidades e inovar de acordo com as novas possibilidades tecnológicas e com as demandas dos usuários finais.

Os resultados apresentam o mercado de SMVA como um ecossistema, baseado em contratos de compartilhamento de receita (revenue share) e na troca de informações estratégicas entre os segmentos do mercado. A integradora atua além de sua capacidade estrutural de integração, posicionando-se como um facilitador, que produz conhecimento estratégico, essencial à vantagem competitiva de todos os setores do mercado de SMVA. 


\subsection{DEMANDAS DE GESTÃO DO CONHECIMENTO DO SETOR DE IMPLANTAÇÃO E O\&M DE EQUIPAMENTOS DE TELECOMUNICAÇÃOES}

Com base nas entrevistas realizadas com os gestores, na análise das planilhas e dos documentos institucionais e nos resultados das avaliações das provas de conceito, verifica-se que a empresa estudada na pesquisa-ação apresenta três demandas principais para iniciar um processo de GC: comunicação interna, EC e padronização de procedimentos.

A empresa tem apresentado crescimento significativo nos últimos anos, ampliando sua carteira de clientes e o número de colaboradores. Porém, devido à dinamicidade do mercado, à atualização tecnológica e à necessidade de cumprir prazos cada vez mais reduzidos na solução de ocorrências, não se observa o desenvolvimento de ações para a integração das equipes e das distintas regiões de atuação, em conformidade com este crescimento.

Desse modo, como observado por um colaborador que participou da pesquisa de satisfação, a empresa constitui-se de um conjunto de "ilhas", que atuam de forma independente, com procedimentos e gestão diferenciados entre si, justificando o contraste revelado na mesma pesquisa no que tange às vantagens e desvantagens desta organização. Não se verifica, portanto, uma padronização de processos de trabalho e a consolidação de uma cultura corporativa, desencadeando na não identificação do colaborador como parte da empresa, que faz com que não utilize o email institucional, não participe das ações de comunicação propostas, e não hesite em trocar de organização.

Identifica-se, portanto, a necessidade de estruturar um canal de comunicação interna, que integre os colaboradores e os diferentes setores da empresa e promova a divulgação das informações institucionais. A receptividade do site interno é positiva, porém demanda divulgação mais intensiva, a fim de sinalizar aos colaboradores a importância de conhecerem a empresa onde trabalham, trocarem experiências, atualizarem seus dados pessoais e esclarecerem dúvidas.

Observa-se, ainda, a demanda por capacitação e atualização dos colaboradores, garantindo seu desempenho de forma concomitante ao desenvolvimento tecnológico que caracteriza o setor de telecomunicações. Devido ao número reduzido de colaboradores atuando no departamento de treinamentos, à entrada constante de novos colaboradores e à dispersão geográfica dos mesmos, a empresa tem buscado 
desenvolver cursos introdutórios intensivos, na modalidade presencial, com duração de um mês, focados no setor técnico. Além do investimento financeiro e do desgaste da equipe que viaja por todo país para treinar grupos reduzidos de colaboradores, o processo não tem sido efetivo, na medida em que não há avaliação de desempenho e que não é possível capacitar todos os novos colaboradores antes que iniciem suas atividades.

Considerando o processo de desenvolvimento dos colaboradores como essencial à GC, foram propostas provas de conceito na modalidade a distância. De modo geral, a receptividade dos recursos educacionais EAD é positiva, demonstrando o interesse dos colaboradores por se atualizarem e se desenvolverem profissionalmente. A modalidade EAD apresenta-se, portanto, como uma solução à EC na empresa estudada, considerando alguns ajustes necessários em relação à interatividade e à diversidade de abordagens e metodologias.

Além de reduzir custos com treinamentos e abranger um público maior, esta modalidade tem potencial para ampliar a quantidade de cursos e inserir os colaboradores do setor administrativo no programa de capacitação/atualização. Há, ainda, a possibilidade de promover a integração dos colaboradores, por meio de fóruns, chats e atividades em grupo, redimensionando a distância física e possibilitando o compartilhamento de dúvidas e soluções sobre equipamentos, rotinas de trabalho, entre outros.

É importante destacar que, de acordo com os resultados da pesquisa de satisfação, a maioria dos colaboradores considera o dia a dia de trabalho repleto de desafios e possibilidades de aprendizado, o que os motiva a trabalhar na empresa e a compartilhar suas experiências. Com base nestes resultados, problemas relacionados ao não compartilhamento de soluções estariam vinculados exclusivamente à ausência de um espaço comum para essa troca, assim como à falta de motivação para utilizá-lo.

Em relação à padronização de procedimentos de trabalho, verifica-se a insatisfação dos colaboradores em relação à inexistência de uma política de cargos e salários, de ações de avaliação de desempenho e de um plano de carreira. Como consequência desta situação, observa-se a falta de expectativa de crescimento profissional; a insatisfação quanto à desigualdade salarial e de benefícios para colaboradores que atuam no mesmo cargo; e a demanda por reconhecimento e pela divulgação de notícias sobre vagas e promoções internas. Desse modo, faz-se 
necessário estruturar um padrão de trabalho e de avaliação dos colaboradores, a fim de otimizar o atendimento de ocorrências, motivá-los a se desenvolverem na empresa e, consequentemente, a compartilharem experiências.

Ao abrir um canal de comunicação com os colaboradores, a empresa tende, ainda, a expandir o conhecimento sobre as demandas dos clientes e, consequentemente, a agregar valor aos serviços prestados, uma vez que os profissionais que atuam em campo vivenciam as expectativas e as necessidades das ORMs. Os resultados da pesquisa complementar, realizada com o responsável pelo setor comercial da empresa estudada e com representantes de ORMs, revelam pontos convergentes, mas também divergentes em relação às expectativas referentes ao contrato de prestação de serviços, o que ressalta a necessidade de se "ouvir" o cliente, como destacou um colaborador na pesquisa de satisfação.

De acordo com os representantes de ORMs, as expectativas ao se contratar uma empresa de implantação e O\&M de equipamentos de telecomunicações estão relacionadas à criação de parcerias; ao atendimento às demandas dentro do prazo; à prestação de serviços de alto nível, aumentando a disponibilidade da rede com o menor custo possível; e a características como experiência, organização, credibilidade e profissionalismo. Para o representante do setor comercial da empresa estudada, por sua vez, as contratantes esperam a execução das atividades de engenharia de instalação, como projetos preliminar e definitivo, assim como a instalação, e a realização de testes e comissionamento do equipamento, com excelência de qualidade e garantia de atendimento de prazo.

Em relação ao fator decisivo ao se escolher a contratada, os respondentes destacam: estrutura operacional (capacidade e market share); experiência de mercado; profissionais capacitados; melhor custo/benefício; entendimento do escopo; e agilidade. De acordo com a empresa estudada, o fator decisivo está relacionado ao preço, à garantia de qualidade e, principalmente, ao comprometimento com os objetivos do cliente.

Quando questionados sobre a existência e os tipos de dificuldades no relacionamento contratante/contratada, os respondentes das ORMs relacionam as seguintes: transparência e qualidade das informações; comunicação; execução do cronograma; baixa capacitação técnica dos profissionais, gerando a necessidade de prestar assistência aos fornecedores; não entendimento do escopo; necessidade constante de treinamento de reciclagem e atualização; escassez de recursos; 
questões contratuais não discutidas previamente; e estrutura operacional reduzida. Já para o representante do setor comercial, as dificuldades se resumem a encontrar o denominador comum entre o tripé preço, prazo e qualidade, o que, segundo ele, engloba o dimensionamento correto para o atendimento satisfatório entre qualidade do serviço prestado versus valor.

Em relação aos diferenciais valorizados na empresa contratada, os respondentes destacam a atuação do líder de projetos/operações como um facilitador; equipe técnica capacitada; alta disponibilidade de atendimento; comunicação eficaz/eficiente; ótimos relatórios; experiência; conhecimento sobre o negócio da contratante; atendimento aos prazos e processos; eficiência no tratamento das falhas; qualidade; capacidade financeira; capilaridade; e instrumental adequado. Para o representante da empresa estudada, os diferenciais são: conhecimento técnico e logístico para dimensionamento e oferta da estrutura adequada às necessidades do contrato, aliados a preços competitivos.

De acordo com os representantes das ORMs, atualmente são entregues pela contratada os seguintes serviços: infraestrutura e instalação de equipamentos; manutenção de HW e SW; gestão de sobressalente; e alocação de recursos humanos com conhecimento de redes de telecomunicações. Eles gostariam, porém, que a fossem oferecidos outros serviços, como: treinamentos e novas tecnologias, com potencial para promover economia em custos de manutenção; e auditoria do cadastro por planta instalada.

As informações estratégicas também são abordadas nesta pesquisa. De acordo com os representantes das ORMs, atualmente a contratada entrega à contratante um cronograma de instalação; um controle mensal com quantidade de tickets; e um boletim com novidades, como atualizações de SW ou novos produtos. Porém, eles relacionam informações que poderiam ser repassadas pela contratada e que agregariam valor a seu negócio, como estado dos equipamentos; necessidade de manutenção; capacidade da estrutura; propostas de melhorias nos locais trabalhados; relatórios de falhas e perda de receita; plano de ação; acompanhamento dos planos; e validação das melhorias aplicadas. O representante da empresa estudada ressalta que há um sistema de gestão que auxilia as ORMs a gerenciarem os recursos financeiros disponíveis para investimento/recuperação da planta de forma otimizada.

Em relação aos impactos devido ao atraso na resolução de ocorrências, os respondentes das ORMs destacam o comprometimento das metas e dos indicadores 
de qualidade; a perda de receita; a insatisfação do cliente final; a desvalorização da marca; o impacto regulatório (multas); e o risco de migração do cliente para outra ORM.

Observa-se, portanto, que, além dos serviços entregues atualmente pela contratada, as ORMs valorizam a capacitação técnica, a comunicação eficiente e ótimos relatórios. Além da implantação e O\&M de seus equipamentos, elas gostariam de receber informações estratégicas, que as permitam desenvolver ações preventivas, e não apenas corretivas, uma vez que os impactos gerados pelas ocorrências são bastante significativos. Neste contexto, é importante destacar a demanda por vínculo de parceria pelas ORMs, o que não é mencionado pelo representante da empresa estudada.

Analisando as informações coletadas na pesquisa-ação e na pesquisa realizada com representantes das ORMs e com o representante comercial da empresa estudada, verifica-se a necessidade de desenvolvimento de um processo de GC que atenda tanto as necessidades internas do setor de infraestrutura de telecomunicações, como as demandas das ORMs, seus principais clientes. Desse modo, assim como a integradora ampliou os serviços oferecidos além da capacidade operacional de sua plataforma, promovendo GC e gerando informação estratégica para todo o setor de SMVA, as empresas de implantação e O\&M de equipamentos de telecomunicações, para atender as expectativas de seus clientes e de seu Cl, devem ampliar sua atuação, entregando valor além de serviços operacionais, e capacitação e reconhecimento além de condições básicas de trabalho.

Para a efetiva GC neste setor, é necessário, portanto, valorizar o $\mathrm{Cl}$ em relação aos demais bens da empresa, desenvolvendo o capital estrutural a partir de ferramentas que permitam a consolidação de um banco de dados de atendimentos, boas práticas e padrões de trabalho, além da consolidação da cultura corporativa; o capital relacional, por meio de um canal efetivo de comunicação interna e da criação de mais oportunidades de diálogo com os clientes e de integração com os colaboradores; e o capital humano, com o desenvolvimento de um programa de capacitação e atualização profissional contínuo, além de valorização das experiências e do desempenho dos colaboradores. 


\section{DISCUSSÃO}

Neste item, apresenta-se a estruturação do modelo de GC para o setor de infraestrutura de telecomunicações, a partir da correlação entre o estudo teórico, as boas práticas observadas no estudo de caso e as demandas identificadas na pesquisa-ação. Esta correlação se faz possível, uma vez que as empresas estudadas possuem contexto e características semelhantes: vivenciam a dinamicidade do setor de telecomunicações; atuam entre as ORMs e os clientes finais, sem estabelecer contato direto com estes; têm as ORMs como clientes principais; contam com desafios semelhantes, como, por exemplo, a adequação às constantes atualizações tecnológicas e a necessidade de manter a sintonia entre capital estrutural, relacional e intelectual para serem competitivas; e são as maiores empresas nacionais em suas respectivas áreas de atuação.

A pesquisa desenvolvida na maior integradora do país permite verificar que o setor SMVA tem trabalhado de modo coopetitivo, competindo e colaborando ao mesmo tempo, de forma a superar a dinamicidade do mercado. A colaboração é um importante fator para economias emergentes para a propensão à inovação (TEMEL; MENTION; TORKKELI, 2013). Jing e Xiong-Jian (2011) também observaram relações de colaboração em seus estudos sobre o mercado de telefonia móvel chinês. Eles concluíram que a cooperação entre empresas parceiras tem sido uma boa oportunidade para criar uma situação ganha-ganha neste negócio.

De acordo com Luo (2004), coopetição é uma nova estratégia que usa regras convencionais de competição e cooperação para combinar vantagens dos competidores. Para Gueguen e Isckia (2001), coopetição constrói a ideia de que competidores não deveriam ser considerados simplesmente rivais na busca pelo domínio do mercado, mas também fontes valiosas de inovação.

Além de estabelecer relações de colaboração, verifica-se que as empresas que atuam neste setor são flexíveis às mudanças tecnológicas e de negócio, sendo capazes de vislumbrar novos desafios e oportunidades em meio aos desafios deste mercado. Como exemplo, destaca-se a percepção dos representantes das ORMs, que participaram do estudo de caso, diante da ameaça dos dispositivos com conexão à Internet. Eles observam oportunidades para novos desafios e para o estabelecimento de parcerias com as lojas de aplicativos. Assim, as oportunidades de mercado constituem o principal insumo estratégico das ORMs. 
A integradora, por sua vez, diante do risco de conexão direta entre provedores de conteúdo e ORMs, tem ampliado seu escopo de atuação, investindo em profissionais qualificados, aptos a oferecerem informações estratégicas e a agregarem valor aos clientes. Os resultados revelam que a GC têm sido, portanto, mais relevante do que a própria capacidade operacional da plataforma de integração.

Verifica-se, portanto, a valorização do $\mathrm{Cl}$ para agregar valor ao serviço prestado ao cliente e estabelecer uma relação na qual todos ganham. $O$ foco desta relação encontra-se, portanto, no usuário final, que detém o poder de escolha em relação às ORMs e aos SMVA. Esta relação corrobora uma das ideias de nova cadeia de valor orientada a serviços, proposta por Tan e Zeng (2009), que destacam o desenvolvimento e fornecimento de negócios de telecomunicações baseados nas demandas práticas dos usuários. Portanto, o diferencial neste mercado está nos serviços que adicionam valor ao usuário final.

Com o foco no usuário final, a GC passa a ser vital às empresas que necessitam prever tendências de comportamento do mercado e manterem-se competitivas. Essa demanda por estar à frente das mudanças, expande-se, portanto, a todo o setor de telecomunicações, como é o caso da empresa de implantação e O\&M estudada. Além de produtos inovadores, as ORMs precisam garantir acesso de qualidade ao consumidor, reduzindo cada vez mais a frequência de ocorrências nas redes de telecomunicações e o tempo de resolução.

Neste contexto, a segunda empresa estudada tem ampliado seu quadro de colaboradores para cumprir os prazos cada vez mais reduzidos. Essa, porém, não conta com um projeto de GC que valorize o $\mathrm{Cl}$ e a IC, o que agregaria valor ao serviço prestado e garantiria profissionais motivados a crescerem na empresa. Observa-se que os colaboradores não se engajam nas ações corporativas, pois esperam mais do que remuneração e benefícios para se sentirem parte do todo. A expectativa é por avaliações sinceras e construtivas em relação ao desempenho, seguidas por reconhecimento.

Utilizando as definições de indivíduos e pessoas propostas por Rocha (1995), é possível dizer que os colaboradores esperam ser tratados como indivíduos (ideologicamente equivalentes) no que tange a direitos e deveres, e como pessoas (ideologicamente diferentes) no que se refere à inserção como membros da empresa, com possibilidade de discutirem processos de trabalho, sugerirem melhorias e compartilharem experiências. 
Desse modo, comparando ambos os estudos, propõe-se um modelo de GC para o setor de infraestrutura de telecomunicações, que prevê o desenvolvimento de sistemas e processos que relevam o principal ativo da empresa: o capital humano. $\mathrm{O}$ modelo relaciona ações concretas para promover resultados mensuráveis e imensuráveis, como é o caso da consolidação da cultura corporativa.

De acordo com Alvarenga Neto (2008), a organização deve fornecer o contexto adequado para a criação e acúmulo do conhecimento (do japonês ba, espaço do conhecimento, lugar ou contexto capacitante). Embora seja mais fácil considerá-lo como um espaço físico como uma sala de reuniões, esse deve ser entendido como interações que ocorrem em um tempo e local específicos (TAKEUCHI; NONAKA, 2008).

Como se trata de uma empresa cujos colaboradores atuam, na maioria das vezes individualmente, considera-se que a criação e o compartilhamento do conhecimento perpassam não apenas pelo processo de aprendizagem com a conversão de conhecimento tácito em explícito, como propuseram Burnham et al. (2005), mas, também, por um canal de comunicação interna, no qual o conhecimento tácito dos colaboradores possa ser compartilhado e codificado, tornando-se explícito e integrando, assim, juntamente com o conhecimento organizacional, os procedimentos da empresa e as ações de EC. Prevê-se, portanto, a criação de dois espaços principais de interação para fomento da GC, que constituem o ba: canal de comunicação interna e SEC.

A figura 12 ilustra a estrutura do modelo. Esse propõe a conversão de conhecimento tácito em conhecimento explícito, assim como o processo inverso, em um ciclo contínuo de GC, por meio dos espaços de interação propostos. 
Figura 12 - Representação gráfica do modelo de GC para o setor de infraestrutura de telecomunicações

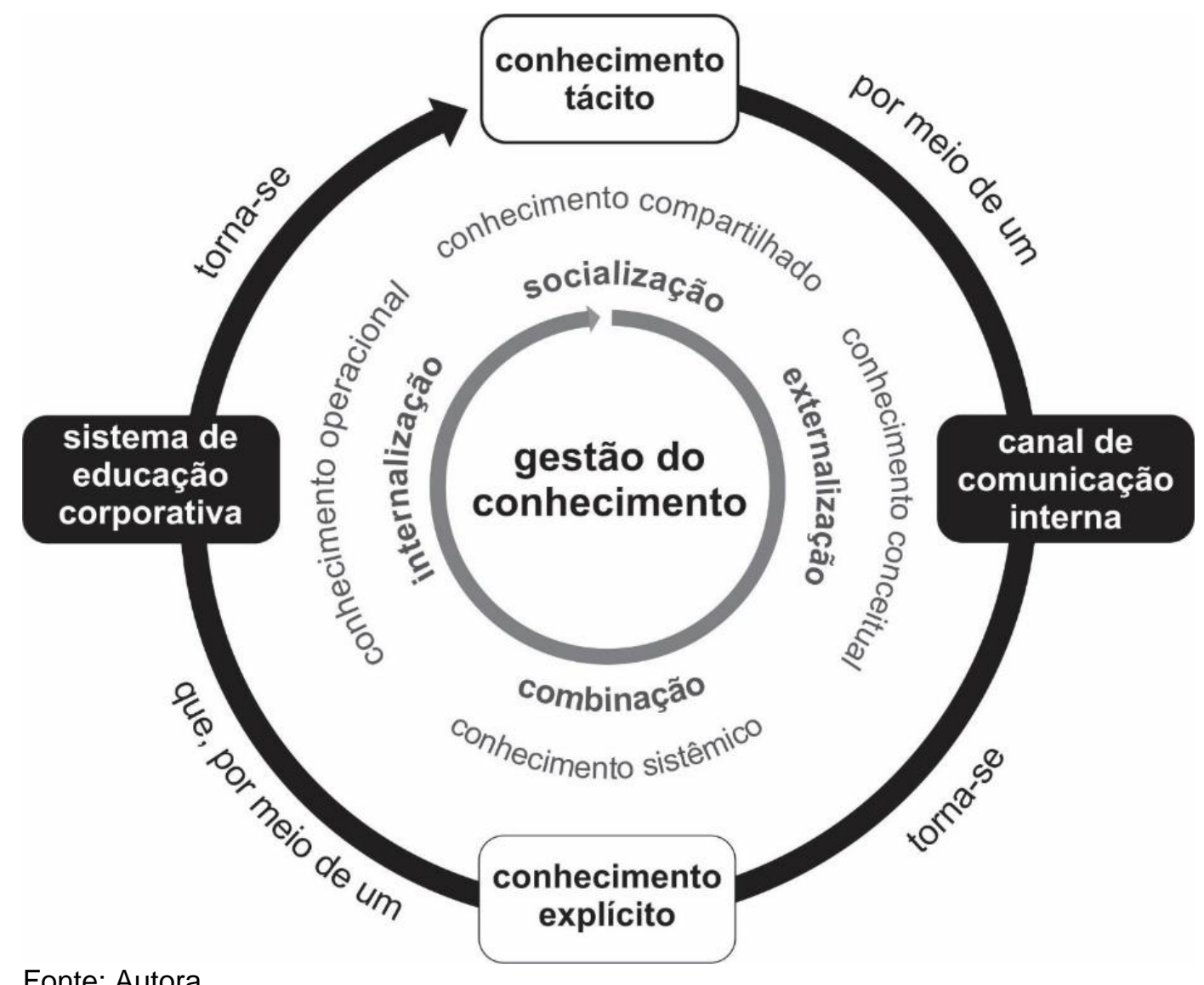

Fonte: Autora.

Considerando a dispersão geográfica dos colaboradores, as frequentes atualizações tecnológicas e as características da GC de direcionar recursos humanos para coletar, armazenar e distribuir conhecimento codificado (ERICKSON; ROTHBERG, 2009), o modelo sugere, incialmente, a conversão de conhecimento tácito em explícito (externalização).

Propõe-se o compartilhamento, entre colaboradores e equipes (socialização), das competências ("saber como") e das percepções do dia a dia em relação às atividades de trabalho e às necessidades dos clientes. A partir da socialização, é prevista a conversão deste conhecimento tácito compartilhado em conhecimento codificado, por meio de um canal de comunicação interna. Quando o conhecimento tácito se transforma em explícito, esse se cristaliza e se torna a base de um novo conhecimento (NONAKA; TOYAMA; KONNO, 2000). Ver figura 13. 
Figura $13-1^{\circ}$ recorte do modelo de GC: conhecimento tácito

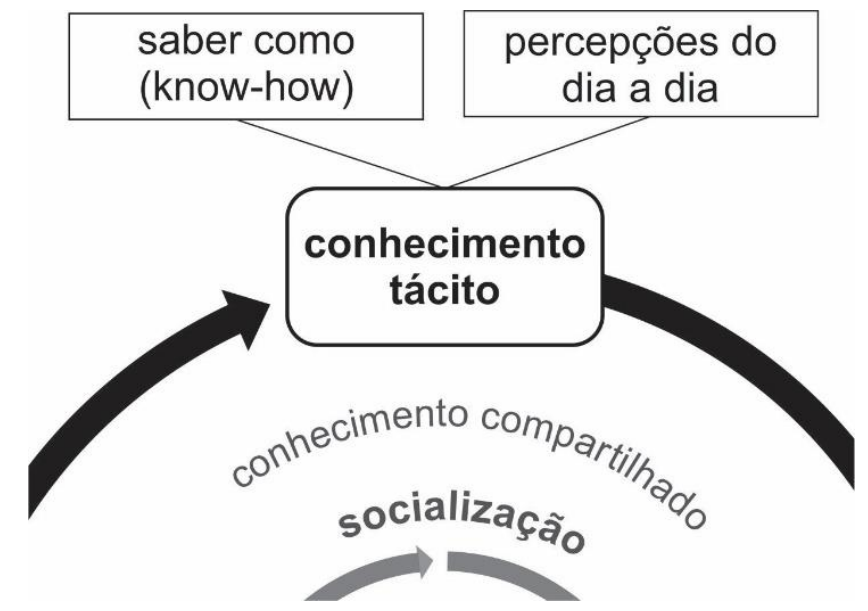

Fonte: Autora.

O canal de comunicação interna é proposto como um ambiente para externalização do conhecimento tácito, gerando conhecimento conceitual a ser disponibilizado a todos os membros da empresa. Este ambiente prevê o acesso às notícias institucionais, o registro e a divulgação de dados dos colaboradores, ocorrências e resoluções inovadoras/criativas, e um sistema de busca fácil de informações, contatos e casos de sucesso.

Reconhecendo a importância do capital humano para a GC e para o negócio da empresa, o objetivo é utilizar este canal para promover ações de engajamento, dando visibilidade ao conhecimento e às experiências dos colaboradores, promovendo o senso de pertencimento, reduzindo o turnover e consolidando a cultura corporativa. Ver figura 14.

Figura $14-2^{\circ}$ recorte do modelo de GC: canal de comunicação interna

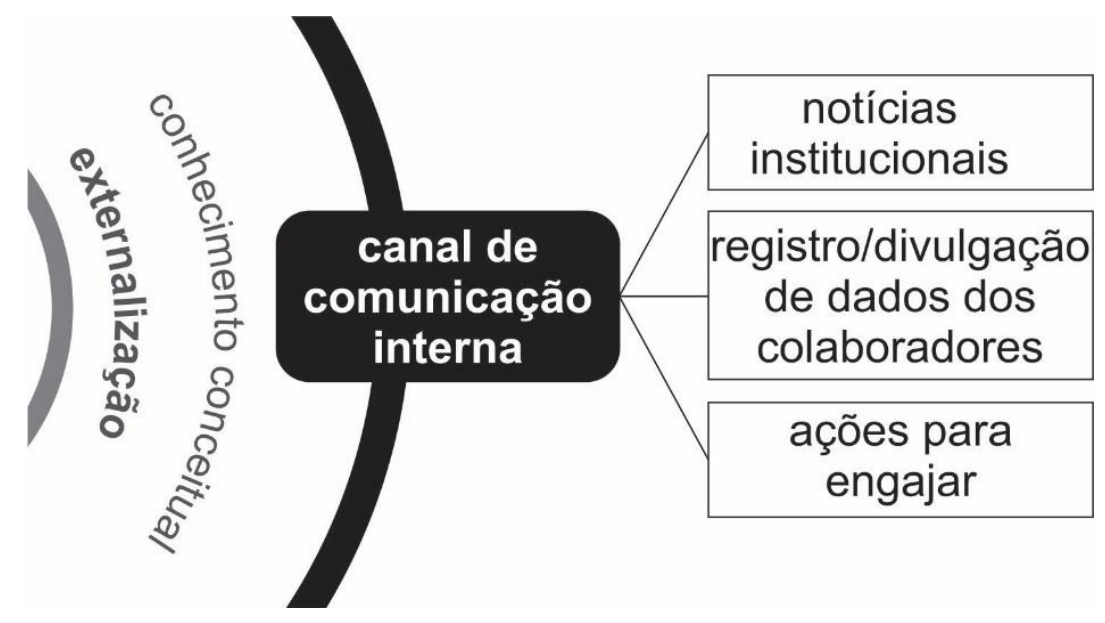

Fonte: Autora. 
Para fechar o ciclo de GC, propõe-se também o movimento inverso, ou seja, a transformação desse conhecimento explícito, elaborado a partir da troca de informações entre as equipes (combinação), em conhecimento tácito por meio de um SEC.

O conhecimento sistêmico deve ser a base para a padronização dos procedimentos de trabalho e rotinas da empresa, conforme Pimenta (2007). Desse modo, a partir dos registros realizados no canal de comunicação, faz-se possível criar um banco de dados com ocorrências recorrentes e boas práticas de atendimento que, ao serem contrastadas com as diretrizes da empresa, consolidem os procedimentos a serem compartilhados com todos os colaboradores (figura 15). Devido à dinamicidade deste setor, este processo deverá ser cíclico e contínuo e considerar a participação ativa dos colaboradores na discussão de padrões de trabalho.

Figura $15-3^{\circ}$ recorte do modelo de GC: conhecimento explícito

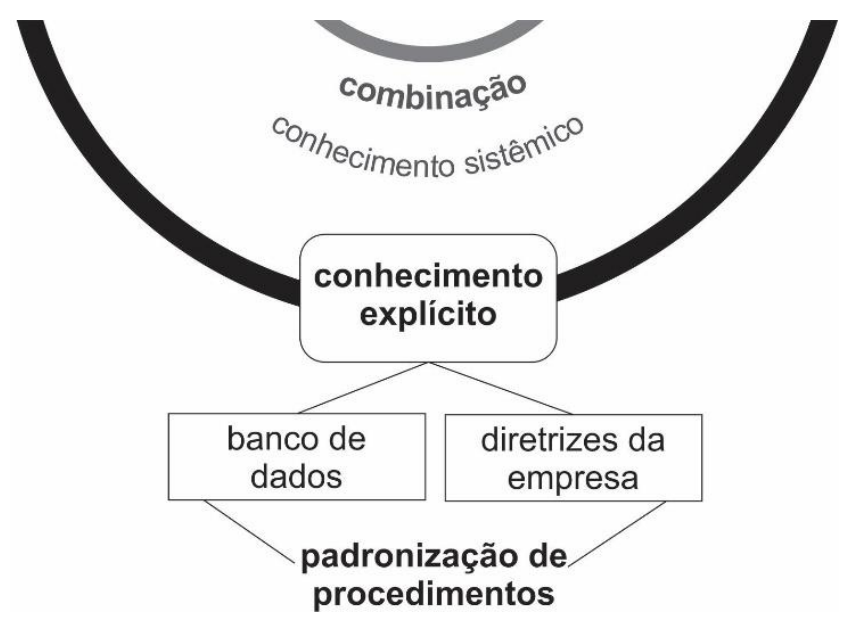

Fonte: Autora.

Considerando que as pessoas aprendem o que precisam aprender (Senge 2006), o SEC propõe o uso de casos e informações do dia a dia, compartilhados pelos colaboradores, como material base para os cursos e para ações de capacitação/atualização profissional, seja por meio de exercícios, exemplos, jogos sérios, entre outros. Desse modo, pretende-se desenvolver recursos educacionais que explorem situações práticas, com potencial para serem assimiladas rapidamente pelos colaboradores, integrando, com o tempo, seu conhecimento tácito. 
Os recursos educacionais deverão ser disponibilizados, preferencialmente, na modalidade EAD, considerando a receptividade das provas de conceito e que, de acordo com Barros (2014), o virtual possibilita tempo diferenciado, espaço diferenciado, atualizações constantes, interação, instantaneidade, desterritorialização, entre outros. Neste contexto, a aprendizagem móvel também deve ser priorizada, uma vez que os colaboradores trabalham em diferentes locais e têm smartphones com acesso à Internet.

O SEC deve estar vinculado diretamente à avaliação de desempenho, uma vez que as capacitações devem ser planejadas com base nas demandas de informação identificadas pelos gestores. Desse modo, os colaboradores devem ser avaliados periodicamente, a fim de se mensurar a eficácia do programa de EC e de se identificar casos de promoção interna, considerando o plano de carreira e as metas da empresa (ver figura 16). Conforme afirma Eboli (2010), a EC deve permear toda a cultura corporativa e fazer parte do cotidiano da organização, e o papel das lideranças empresariais é crucial nesse sentido.

Figura 16 - 4ํㅜㄹ recorte do modelo de GC: SEC

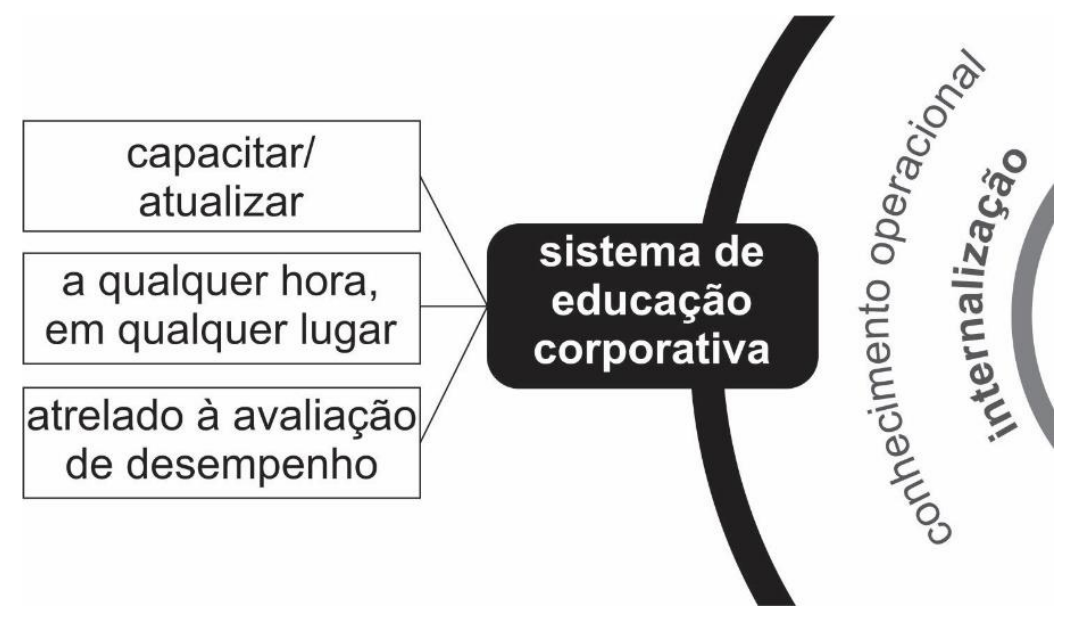

Fonte: Autora.

Este modelo pretende promover a experiência do usuário e a aprendizagem contextualizada, personalizada, colaborativa e interativa, ao mesmo tempo em que objetiva otimizar o uso estratégico do $\mathrm{Cl}$ da empresa. De acordo com Pinto (2011), especialistas da GC estimam que $70 \%$ do $\mathrm{Cl}$ de uma organização não têm existência física, isto é, não ficam documentados em nenhuma base de dados. É aquele 
conhecimento que está diluído na competência de seus colaboradores, desestruturado, porém vital para os negócios.

O modelo postula, portanto, que, em setores dinâmicos como o de telecomunicações, o processo de GC deva prever o compartilhamento do conhecimento dos colaboradores, sua transformação em conhecimento explícito, acessível a toda a organização e aplicado nas ações de EC, e, então sua conversão em conhecimento tácito, elaborado a partir da confrontação com as experiências prévias dos envolvidos. 


\section{CONCLUSÕES}

O estudo propõe um modelo de GC para o setor de infraestrutura de telecomunicações, a partir de duas pesquisas realizadas na maior integradora de SMVA e na principal empresa de implantação e O\&M de equipamentos de telecomunicações do país. Ambas as empresas contam com desafios semelhantes em relação à dinamicidade do mercado e possuem as ORMs como clientes principais.

A integradora caracteriza-se por uma GC eficaz, que a tem mantido no mercado, permitindo-a ampliar seu escopo de atuação e gerar vantagem competitiva a todos os envolvidos no ecossistema de SMVA. Observa-se a priorização do capital humano em detrimento da plataforma operacional de integração e a relação coopetitiva neste setor.

A empresa de implantação e O\&M de equipamentos de telecomunicações caracteriza-se, por sua vez, pela ampliação de sua carteira de clientes e pela expansão significativa de seu quadro de colaboradores, nos últimos anos. Porém, diante da constante atualização tecnológica, da dispersão geográfica das equipes e da pressão pela redução do tempo na resolução de ocorrências por parte das ORMs, a empresa tem encontrado dificuldades para capacitar/atualizar seus colaboradores, integrá-los e desenvolver um sistema efetivo de GC.

Considerando a valorização do capital humano no primeiro estudo, propôs-se, além de entrevistas com o presidente e gestores da empresa, provas de conceito e pesquisas para conhecer a percepção e as demandas dos colaboradores. Identificouse como necessidades principais: treinamento, reconhecimento, estabelecimento de padrões de trabalho e avaliação de desempenho. Verificou-se, também, a receptividade em relação aos recursos educacionais disponibilizados na modalidade EAD e com acesso móvel.

Observa-se três demandas principais no segundo estudo: comunicação interna, EC e padronização de procedimentos de trabalho. Propõe-se, portanto, um modelo que prevê dois espaços para troca de informações e interações: um canal de comunicação interna, que visa a reduzir a distância física entre os colaboradores e promover o compartilhamento de experiências; e um SEC, que integre todas as ações de EC.

Com base na integração destes dois espaços, que já foram estruturados como provas de conceito devendo ser aprimorados pela empresa, prevê-se um ciclo de 
conversão de conhecimento tácito em explícito e, também, de explícito em tácito, que considera as experiências dos colaboradores na otimização do atendimento de ocorrências. Almeja-se a promoção do compartilhamento e da divulgação de experiências e casos de sucesso; a estruturação dos procedimentos de trabalho, a partir da consolidação de um banco de dados com registro de ocorrências; e o desenvolvimento de um programa de EC, que priorize a prática, utilizando as informações compartilhadas pelos colaboradores na elaboração de recursos educacionais diversos, como exercícios, avaliações e jogos.

Neste contexto, prioriza-se o capital humano em detrimento das demais formas de $\mathrm{Cl}$, uma vez que o desempenho do capital estrutural depende do conhecimento dos colaboradores e que a promoção do capital relacional também passa pela sua atuação, pois estão diretamente em contato com o contexto e as demandas dos clientes.

O modelo de GC para o setor de infraestrutura de telecomunicações prevê, portanto, o engajamento de gestores e colaboradores para iniciar uma proposta de cultura de compartilhamento com troca de informações e experiências, que tende a agregar valor e vantagem competitiva a todos os envolvidos no ecossistema. Esta dinâmica corrobora a afirmação de Kahaner (1996), de que a informação deve ser compartilhada para que o sistema de IC funcione.

Assim, com sua implementação, espera-se: a integração dos colaboradores, por meio de um canal de comunicação interna e de ações de engajamento e reconhecimento; a padronização de procedimentos de trabalho; o desenvolvimento de um programa de EC contínuo, que garanta a capacitação/atualização de todos os colaboradores just-in-time, ou seja, de modo sincronizado às atualizações tecnológicas; o reconhecimento do capital humano e de seu conhecimento como principais ativos da empresa; e a otimização do atendimento aos clientes, entregando valor além de suporte técnico, por meio de análises estratégicas e preventivas das redes de telecomunicações.

Apesar das limitações do estudo, relacionadas principalmente ao número de empresas estudadas, esse permite compreender o dinamismo do setor de telecomunicações, os principais desafios e as soluções encontradas, diretamente vinculadas à GC. Para estudos futuros, propõe-se a implementação do modelo, a partir do engajamento dos gestores e da avaliação da eficácia de cada ação em grupos de controle maiores, a fim de aprimorá-lo. 


\section{REFERÊNCIAS}

ABED, Associação Brasileira de Educação a Distância. Censo EAD.BR: relatório analítico da aprendizagem a distância no Brasil 2013. Curitiba: Ibpex, 2014.

Disponível em:

<http://www.abed.org.br/censoead2013/CENSO_EAD_2013_PORTUGUES.pdf >. Acesso em: 20 nov. 2014.

ALVARENGA NETO, R. C. D. Gestão do conhecimento em organizações: proposta de mapeamento conceitual integrativo. São Paulo: Saraiva, 2008. 236 p.

ALVES, L. R. G. Estratégia de jogos na EAD. In: LITTO, F. M.; FORMIGA, M. M. M. (Org.). Educação a distância: o estado da arte. São Paulo: Pearson Education do Brasil, 2008. p. 141-146.

ARMSTRONG, T. Inteligências múltiplas na sala de aula. 2. ed. Tradução de Maria Adriana Veríssimo Veronese. Porto Alegre: Artmed, 2000.

BATAGLIA, W.; PINTO, A.C. A influência da privatização no posicionamento das operadoras de rede: o caso brasileiro. In: VII SEMINÁRIOS EM ADMINISTRAÇÃO, 2004, São Paulo. Anais do VII SEMEAD, 2004, v.1.

BATIVA, G. B. Ferramenta de Identificação de Perfis de Aprendizes (FIPA). 2011. 142 p. Dissertação (Mestrado) - Universidade Federal do ABC (UFABC), Santo André, 2011. Disponível em: <http://www.files.scire.net.br/atrio/ufabcposinfo_upl//THESIS/30/dissertacao_final_gilberto_bravos_bativa.pdf>. Acesso em: 20 nov. 2013.

BARROS, D. M. V. Estilos de aprendizagem e o uso das tecnologias. 1. ed. São Paulo: Artesanato Educacional, 2014.

BASOLE, R. C. Visualization of interfirm relations in a converging mobile ecosystem. In: 7th INTERNATIONAL CONFERENCE ON MOBILE BUSINESS, 2008, Barcelona, p. 65-74. Disponível em: <http://dx.doi.org/10.1109/ICMB.2008.32>. Acesso em: 10 abr. 2014.

BIBOLINI, L.; LANCASTER, H. Latin America - telecoms, mobile and broadband overview. 11. ed. 2014. Disponível em: <http://www.budde.com.au/Research/2014Latin-America-Telecoms-Mobile-and-Broadband-Overview.html\#toc>. Acesso em: 20 jan. 2015.

BRASIL (País). Lei Geral das Telecomunicações no 9.472, de 16 de julho de 1997. Dispõe sobre a organização dos serviços de telecomunicações, a criação e funcionamento de um órgão regulador e outros aspectos institucionais, nos termos da Emenda Constitucional ํㅜ 8, de 1995. Disponível em:

<http://www.planalto.gov.br/ccivil_03/leis//9472.htm>. Acesso em: 15 mar. 2014.

BUENO, W. C. Comunicação empresarial: políticas e estratégias. São Paulo: Saraiva, 2009. 
BURNHAM, T. F.; ALVES, R. M.; MORAES, I. O.; MORAES, R. L. Aprendizagem organizacional e gestão do conhecimento. In: VI CINFORM - ENCONTRO NACIONAL DE CIÊNCIA DA INFORMAÇÃO, 2005, Salvador. Disponível em: $<$ http://www.cinformanteriores.ufba.br/vi_anais/docs/TeresinhaRenatolsabelRamone.pdf>. Acesso em: 05 maio 2014.

CASTELLS, M. A sociedade em rede - a era da informação: Economia, Sociedade e Cultura, v.1. Tradução de Roneide Venâncio Majer. São Paulo: Paz e Terra, 2007.

CERVEIRA, P. A gestão do conhecimento pelo uso de plataforma de e-learning para organizações geradoras de conhecimento. In: CONGRESSO NACIONAL DE EXCELẾNCIA EM GESTÃO, 2011, Rio de Janeiro. Disponível em: <http://www.inovarse.org/filebrowser/download/8555> Acesso em 11 mar. 2015.

CHIAVENATO, I. Gestão de pessoas: o novo papel dos recursos humanos nas organizações. 3. ed. Rio de Janeiro: Elsevier, 2010.

$\mathrm{CHOO}, \mathrm{C}$. W. The art of scanning the environment. Bulletin of the American Society for Information Science, v. 25, p. 21-24, 1999. Disponível em: <http://dx.doi.org/10.1002/bult.117>. Acesso em: 30 abr. 2015.

CNI. Sondagem especial - falta de trabalhador qualificado na indústria. 2011. Disponível em: <http://admin.cni.org.br/portal/data/pages/FF808081314EB36201314F2228FF6E5C. htm\#descricao> Acesso em: 25 maio 2013.

COGO, R. S. Comunicação interna e storytelling: uma lógica de estruturação do pensamento e de difusão de narrativas. In: NASSAR, P. Comunicação interna: a força das empresas. São Paulo: Aberje, 2013. p. 47-54.

DE LUCA, R. Educação a distância: ferramenta sob medida para o ensino corporativo. In: SILVA, M. (Org.). Educação online. 3. ed. São Paulo: Edições Loyola, 2011. p. 479-489.

DUARTE, J.; BARROS, A. (Org.). Métodos e técnicas de pesquisa em comunicação. São Paulo: Atlas, 2005.

EBOLI, M. Fundamentos e evolução da educação corporativa. In: EBOLI, M. et al. Educação corporativa: fundamentos, evolução e implantação de projetos. São Paulo: Atlas, 2010. p. 122-139.

ERICKSON, G. S.; ROTHBERG, H. N. Intellectual capital in business-to-business markets. Industrial Marketing Management, v. 38, n. 2, p. 159-165, 2009.

FAHEY, L. Connecting strategy and competitive intelligence: refocusing intelligence to produce critical strategy inputs. Strategy \& Leadership, v. 35, p. 4-12. 2007. Disponível em: <http://dx.doi.org/10.1108/10878570710717236>. Acesso em: 03 mar. 2014. 
FERREIRA, A. A. Comunicação para a qualidade. Rio de Janeiro: Equipe Qualitymark, 2004.

FISCHER, A. L.; AMORIM, W. A. C. Gestão do conhecimento e educação corporativa: integração, complementaridade e sobreposições. In: EBOL̉, M. et al. Educação corporativa: fundamentos, evolução e implantação de projetos. São Paulo: Atlas, 2010. p. 199-219.

FLEURY, M. T. L.; OLIVEIRA JR., M. M. (Org.) Gestão estratégica do conhecimento: integrando aprendizagem, conhecimento e competências. São Paulo: Atlas, 2001.

FRIES, F. H. Estudo do mercado de valor de serviço agregado de telefonia móvel. 2011. 76 p. Trabalho de Conclusão de Graduação - Universidade Federal do Rio Grande do Sul (UFRGS), 2011. Disponível em:

<http://hdl.handle.net/10183/33262>. Acesso em: 15 out. 2013.

FUNDAÇÃO INSTITUTO DE ADMINISTRAÇÃO (FIA). Política de uso do banco de dados: pesquisa as melhores empresas para você trabalhar. 2011. Disponível em: <http://www.progep.org.br/MelhoresEmpresas/InfoDocs/Manual\%20de\%20pol\%C3\% ADticas\%20de\%20dados\%20_\%202011.pdf>. Acesso em: 02 fev. 2015

GARDNER, H. Inteligências múltiplas: a teoria na prática. Tradução de Maria Adriana Veríssimo Veronese. Porto Alegre: Artmed, 1995.

GIL, J. Aproximación interpretativa al contenido de la información textual. In: Análisis de datos cualitativos. Aplicaciones a la investigación educativa. Barcelona: PPU. 1994. p.65-107.

GODOY, A. S. Estudo de caso qualitativo. In: GODOI, C. K.; BANDEIRA-DEMELLO, R.; SILVA, A. B. Pesquisa qualitativa em estudos organizacionais: paradigmas, estratégias e métodos. 1. ed. São Paulo: Saraiva, 2006. p. 115-145.

GSMA Intelligence; BCG - The Boston Consulting Group. Mobile economy Latin America 2013. Disponível em: <http://gsma.com/newsroom/wpcontent/uploads/2013/12/GSMA_ME_LatAm_Report_2013.pdf>. Acesso em: 15 jan. 2015.

GSMA Intelligence. The mobile economy 2014. Disponível em: <http://www.gsmamobileeconomy.com/> Acesso em: 10 mar. 2015).

GSMA mWomen; CHERIE BLAIR Foundation for Women; EXXONMOBIL Foundation; BOOZ \& Company UK. Mobile value added services: a business growth opportunity for women entrepreneurs. 2012. Disponível em: < http://www.cherieblairfoundation.org/wp-content/uploads/2012/07/Mobile-ValueAdded-Services-digital-report.pdf>. Acesso em: 30 maio 2014.

GUISASOLA, J.; FURIÓ, C.; CEBERIO, M. Science education based on developing guided research. In: THOMASE, M. V. Science Education in Focus. New York: Nova Science Publishers, 2006. p. 55-85. 
GUEGUEN, G., ISCKIA, T. (2011). The borders of mobile handset ecosystems: is coopetition inevitable? Telematics and Informatics, v. 28, p. 5-11, 2011. Disponível em: < http://dx.doi.org/10.1016/j.tele.2010.05.007>. Acesso em: 30 mar. 2015.

HEINRICHS, J. H.; LIM, J. S. Integrating web-based data mining tools with business models for knowledge management. Decision Support Systems, v. 35, n. 1, p. 103112. 2003. Disponível em: <http://dx.doi.org/10.1016/S0167-9236(02)00098-2>. Acesso em: 12 mar. 2014.

IGNÁCIO, R. F. Aprendendo mecânica dos fluidos por meio da escola da vida. In: MASETTO, M. T. Ensino de engenharia - técnicas para otimização das aulas. São Paulo: AVERCAMP, 2007. p. 107-124.

JAGANNATH, S. Over-the-top with the telecom industry. In: INDIA 2013: technology 'medley' is on the menu - eat wisely to enjoy it!, 2013, p. 25-46. Disponível em: $<$ http://www.connect-world.com/index.php/magazines/india/itemlist/category/1168india-2013>. Acesso em: 10 jan. 2015.

JENKINS, H. Cultura da convergência. Tradução de Susana Alexandria. São Paulo: Aleph, 2008.

JING, Z., XIONG-JIAN, L. Business ecosystem strategies of mobile network operators in the $3 \mathrm{G}$ era: the case of China Mobile. Telecommunications Policy, $v$. 35, n. 2, p. 156-171, 2011. Disponível em: <http://dx.doi.org/10.1016/j.telpol.2010.12.009>. Acesso em: 02 jun. 2014.

JOHNSON, L.; ADAMS BECKER, S.; ESTRADA, V.; FREEMAN, A. NMC Horizon Report: 2014. Higher Education Edition. Austin, Texas: The New Media Consortium, 2014. Disponível em: <http://www.nmc.org/publication/nmchorizon-report-2014-higher-education-edition/>. Acesso em: 02 maio 2014.

KAHANER, L. Competitive intelligence: how to gather, analyze, and use information on move your business to the top. Touchstone Book. New York: Simon \& Schuster, 1996.

KAPP, K. M.; BLAIR, L.; MESCH, R. The gamification of learning and instruction fieldbook: ideas into practice. San Francisco: Wiley, 2013.

KEEGAN, D. The incorporation of mobile learning into mainstream education and training. In: 4th WORLD CONFERENCE ON MLEARNING, 2005, Cape Town, South Africa, p. 25-28. Disponível em: <http://www.mlearn.org.za/CD/papers/keegan1.pdf>. Acesso em: 10 out. 2012.

LEE, V.; SCHNEIDER, H.; SCHELL, R. Aplicações móveis: arquitetura, projeto e desenvolvimento. Tradução de Amaury Bentes e Deborah Rüdiger. Revisão técnica Renato Haddad. São Paulo: Pearson Education do Brasil, 2005. p. 1-22.

LIMA, L. J. B. Engajamento e motivação - como as pessoas fazem a diferença. In: NASSAR, P. Comunicação interna: a força das empresas. São Paulo: Aberje, 2013. p. 21-28. 
LUO, Y. Coopetition in international business. Denmark: Copenhagen Business School Press, 2004.

MARTINS, G. A.; THEÓPHILO, C. R. Metodologia da investigação científica para ciências sociais aplicadas. São Paulo: Atlas, 2007.

MARUTA, R. The creation and management of organizational knowledge.

Knowledge-Based Systems, v. 67, p. 26-34, 2014. Disponível em:

<http://dx.doi.org/10.1016/j.knosys.2014.06.012>. Acesso em: 20 out. 2015.

MEDINA, B.; VIANNA, Y.; VIANNA, M.; TANAKA, S. Gamification, Inc.: como reinventar empresas a partir de jogos. 1. ed. Rio de Janeiro: MJV Press, 2013. 164 p.

MORAES, M. C. O paradigma educacional emergente. 7. ed. Campinas: Papirus, 2001.

MOREIRA, M. G. A composição e o funcionamento da equipe de produção. In: LITTO, F. M.; FORMIGA, M. M. M. (Org.). Educação a distância: 0 estado da arte. São Paulo: Pearson Education do Brasil, 2009.

MOZZAQUATRO, P. M.; MEDINA, R. D. Modelagem de um framework para adaptação de ambientes virtuais de aprendizagem móveis aos diferentes estilos cognitivos. Revista Novas Tecnologias na Educação, CINTED-UFRGS, v. 7, n. 3 , 2009. Disponível em: <http://seer.ufrgs.br/renote/article/viewFile/13565/8835>. Acesso em: 08 ago. 2011.

MYLONOPOULOS, N. A.; SIDERIS, I. A. Growth of value added mobile services under different scenarios of industry evolution. Eletronic Markets, v. 16, n. 1, p. 2840. 2006. Disponível em: <http://dx.doi.org/10.1080/10196780500491105>. Acesso em: 20 abr. 2014.

NICOLESCU, B. O manifesto da transdisciplinaridade. Tradução de Lucia Pereira de Souza. São Paulo: TRIOM, 1999. 167 p.

NIKOU, S., MEZEI, J. Evaluation of mobile services and substantial adoption factors with Analytic Hierarchy Process (AHP). Telecommunications Policy, v. 37, n. 10, p. 915-929, 2013. Disponível em: <http://dx.doi.org/10.1016/j.telpol.2012.09.007>. Acesso em: 15 nov. 2014.

NONAKA, I.; TOYAMA, R.; KONNO, N. SECl, ba and leadership: a unified model of dynamic knowledge creation. In: Long Range Planning, 33, 2000, p. 5-34.

Disponível em: <http://dx.doi.org/10.1016/S0024-6301(99)00115-6> Acesso em: 15 mar. 2013. 
NOVA, C.; ALVES, L. Tempo, espaço e sujeitos da educação à distância. In:

Internet e educação a distância. 1. ed. Salvador: Edufba, v. 1, 2002, p. 41-55.

Disponível em: <http://www.smec.salvador.ba.gov.br/site/documentos/espaco-

virtual/espaco-edu-com-

tec/publicacoes/tempo\%20espaco\%20e\%20sujeitos\%20da\%20educacao\%20a\%20d istancia.pdf>. Acesso em: 08 abr. 2010.

NUNES, I. B. A história da EAD no mundo. In: LITTO, F. M.; FORMIGA, M. M. M. (Org.). Educação a distância - o estado da arte. São Paulo: Pearson Education do Brasil, 2008. p. 2-8.

OLIVEIRA JR., M. M. Competências essenciais e conhecimento na empresa. In: FLEURY, M. T. L.; OLIVEIRA JR., M. M. (Org.). Gestão estratégica do conhecimento: integrando aprendizagem, conhecimento e competências. São Paulo: Atlas, 2001. p. 121-156.

PIMENTA, M. A. Comunicação empresarial. 5. ed. São Paulo: Alínea, 2007.

PIMENTA, S. G. Formação de professores: saberes da docência e identidade do professor. In. FAZENDA, I. C. A. Didática e interdisciplinaridade. 8. ed. Campinas: Papirus, 2003. p. 161-178.

PINTO, A. L. S. A. EAD e educação corporativa: caminhos cruzados. In: SILVA, M. (Org.). Educação online. 3. ed. São Paulo: Edições Loyola, 2011. p. 491-498.

PURE, B. Fazendo negócios móveis no Brasil - como montar ou rentabilizar os negócios usando tecnologias móveis através da telefonia celular no Brasil. 2012. Disponível em: <issuu.com/purebros/docs/bt5_livro_doing_portugues>. Acesso em: 20 jan 2013.

REFERENCIAIS de qualidade para educação superior a distância. Ministério da Educação - Secretaria de Educação a Distância. Brasília, agosto 2007. Disponível em: <http://portal.mec.gov.br/seed/arquivos/pdf/legislacao/refead1.pdf>. Acesso em 26 fev. 2010.

RICHARD, I. Indústria pede educação para o mercado de trabalho. Agência Brasil, Brasília, 28 out. 2013. Disponível em:

$<$ http://memoria.ebc.com.br/agenciabrasil/noticia/2013-10-28/industria-pedeeducacao-para-mercado-de-trabalho>. Acesso em: 30 jan. 2014.

RICHARDSON, R. J. Pesquisa social - método e técnicas. 3. ed. São Paulo: Atlas, 1999.

ROCHA, E. A sociedade do sonho - comunicação, cultura e consumo. 2. ed. Rio de Janeiro: Mauad, 1995.

ROSEN, A. E-learning 2.0: proven practices and emerging technologies to achieve results. New York: Amacom, 2009. 256 p. 
SABBAG, P. Y. Gestão de projetos e educação corporativa. In: EBOLI, M. et al. Educação corporativa: fundamentos, evolução e implantação de projetos. São Paulo: Atlas, 2010. p. 252-274.

SENGE, P. M. A quinta disciplina - arte e prática da organização que aprende. Tradução de OP Traduções. Consultoria Zumble Aprendizagem Organizacional. 21. ed. Rio de Janeiro: BestSeller, 2006.

SILVA, R. S. A educação corporativa: universidades corporativas. In: LITTO, F.; FORMIGA, M. (Org.). Educação a distância: estado da arte. 1. ed. São Paulo: Pearson Education do Brasil, 2009. p. 230-236.

SILVEIRA, A. B. Os processos da estratégia de inovação na cadeia de valor do setor de telefonia móvel. Negócios e Talentos, v. 5, n. 5, 2008. Disponível em: <http://seer.uniritter.edu.br/index.php/negocios/article/view/123/45>. Acesso em: 12 fev. 2014.

STRINGER, E. T. Action research. 3. ed. USA: Sage Publications, 2007. 279 p.

TAKEUCHI, H.; NONAKA, I. Gestão do conhecimento. Tradução de Ana Thorell. Porto Alegre: Bookman, 2008. 320 p.

TAN, Y., Zeng, J. Study on value chain of telecom VAS under transformation background. Communications and Network, v. 1, n. 2, p. 63-67, 2009. Disponível em: <http://dx.doi.org/10.4236/cn.2009.12010>. Acesso em: 20 abr. 2014.

TATSCH, C. R. Privatização do setor de telecomunicações no Brasil. 2003. 318 p. Dissertação (Mestrado) - Universidade Federal do Rio Grande do Sul (UFRGS), Porto Alegre, 2003. Disponível em:

$<$ http://www.lume.ufrgs.br/bitstream/handle/10183/2961/000379728.pdf?sequence $=1$ >. Acesso em: 12 fev. 2014.

TEECE, D. J. Business models, business strategy and innovation. Long Range Planning, v. 43, p. 172-194, 2010. Disponível em: <http://dx.doi.org/10.1016/j.Irp.2009.07.003>. Acesso em: 15 out. 2015.

TELEBRASIL; TELECO. O setor de telecomunicações no Brasil - uma visão estruturada. 2014. Disponível em: <http://www.telebrasil.org.br/panorama-do-setor/osetor-de-telecomunicacoes>. Acesso em: 09 dez. 2015.

TELECO intelligence in telecommunications. 2016. Disponível em: <http://www.teleco.com.br>. Acesso em: 20 jan. 2016.

TELECO (Brasil). O desempenho do setor de telecomunicações no Brasil séries temporais, preparado pelo Teleco para a Telebrasil. 2014. Disponível em: <http://www.teleco.com.br/estatis.asp>. Acesso em: 09 dez. 2015. 
TEMEL, S.; MENTION, A.; TORKKELI, M. (2013). The impact of cooperation on firms' innovation propensity in emerging economies. Journal of Technology Management \& Innovation, v. 8, n. 1, p. 54-64. Disponível em: <http://dx.doi.org/10.4067/S0718-27242013000100006>. Acesso em: 14 set. 2014.

TORI, R. Educação sem distância. As tecnologias interativas na redução de distâncias em ensino e aprendizagem. São Paulo: Ed. SENAC, 2010. 254 p.

TRAXLER, J. Current state of mobile learning. In: ALLY, M. Mobile learning transforming the delivery of education and training. Canada: Athabasca University Press, 2009. p. 9-24. Disponível em:

<http://www.aupress.ca/books/120155/ebook/99Z_Mohamed_Ally_2009-

MobileLearning.pdf>. Acesso em: 10 abr. 2010.

TRIPP, D. Pesquisa-ação: uma introdução metodológica. Educação e Pesquisa, São Paulo, v. 31, n. 3, p. 443-466, 2005.

TUCKER, T. G.; WINCHESTER, W. W. Mobile learning for just-in-time applications. In: 47th ANNUAL SOUTHEAST REGIONAL CONFERENCE ACM. New York, USA, 2009. Disponível em: <http://dx.doi.org/10.1145/1566445.1566469>. Acesso em: 08 ago. 2011.

UNESCO. O futuro da aprendizagem móvel: implicações para planejadores e gestores de políticas. Brasília: 2014. 64 p. Disponível em:

<http://unesdoc.unesco.org/images/0022/002280/228074POR.pdf>. Acesso em: 27 nov. 2015.

VALLE, A. B. Gestão da tecnologia da informação. Rio de Janeiro: Editora FGV, 2013. $232 \mathrm{p}$.

VIEIRA, A. Carga tributária e burocracia prejudicam setor de telecomunicações, dizem empresas. Agência Senado, 30 out. 2013. Disponível em:

<http://www12.senado.gov.br/noticias/materias/2013/10/30/carga-tributaria-eburocracia-prejudicam-setor-de-telecomunicacoes-dizem-empresas>. Acesso em: 25 jan. 2014.

WANG, J.; YU, Y.; SUN, H. The design and realization of mobile learning system based on WAP. In: 3rd IEEE INTERNATIONAL CONFERENCE ON COMPUTER SCIENCE AND INFORMATION TECHNOLOGY (ICCSIT), v. 9, Chengdu, 2010, p. 770-773. Disponível em <http://dx.doi.org/10.1109/ICCSIT.2010.5564536>. Acesso em: 08 ago. 2011

YIN, R. Estudo de caso: planejamento e métodos. 3. ed. Porto Alegre: Bookman, 2005.

YORDANOVA, K. Mobile learning and integration of advanced technologies in education. In: COMPSYSTECH'0, 2007, New York, USA. Proceedings of the International Conference on Computer Systems and Technologies. Disponível em <http://dx.doi.org/10.1145/1330598.1330695>. Acesso em: 08 ago. 2011. 
ZHANG, Y.; LI, J. Application of 3G-based mobile learning in teacher training. In: FOURTH INTERNATIONAL CONFERENCE ON INFORMATION AND COMPUTING (ICIC), Phuket Island, 2011. p. 27-29. Disponível em:

<http://dx.doi.org/10.1109/ICIC.2011.39>. Acesso em: 20 nov. 2013.

ZHUANG, L.; YAN, D.; XIAOYAN, C. Mobile learning applied research based on 3G technology. In: SEVENTH ACIS INTERNATIONAL CONFERENCE ON SOFTWARE ENGINEERING RESEARCH, MANAGEMENT AND APPLICATIONS. Haikou, China, 2009. p. 173-175. Disponível em: <http://dx.doi.org/ 10.1109/SERA.2009.39>.

Acesso em: 08 ago. 2011. 


\section{APÊNDICE A}

Questões sobre SMVA e a estrutura do mercado brasileiro de telecomunicações Respondentes: representantes da integradora estudada

1. Como analisa o mercado de telecomunicações brasileiro?

- quais são os principais players e serviços?

- como se estrutura a produção e a distribuição de SMVA?

2. Como definiria o negócio da empresa?

- quais são os principais serviços?

- a empresa está mais orientada para consumidores finais ou para negócios?

3. Quais são os recursos, infraestrutura e áreas do conhecimento que compõem a empresa?

4. Quais são os principais clientes?

- como se dá o relacionamento e a troca de informações com os clientes?

5. A empresa promove gestão do conhecimento?

- a plataforma de integração armazena dados de relacionamento com cliente e/ou comportamento do consumidor final?

- qual é a importância da gestão do conhecimento para vantagem competitiva da empresa?

6. Como é feito o monitoramento ambiental?

- quais são as principais informações estratégicas para a empresa: oportunidades, concorrência, riscos, vulnerabilidades, suposições, tendências...?

- o ambiente monitorado é interno ou externo?

- quais são as ferramentas utilizadas para o monitoramento ambiental?

- quais são as principais fontes de informação?

7. A empresa utiliza alguma ferramenta de Business Intelligence ou sistemas de suporte à decisão?

8. A empresa investe em inovação?

- se sim, como ocorre o processo de gestão da inovação?

9. Como a empresa otimiza o capital humano, capital estrutural e capital relacional?

- há foco maior para uma das formas de capital?

- como se dá a aprendizagem organizacional? 
10. Considera que em sua função obtém informações importantes para o negócio da empresa?

- se sim, como ocorre a coleta e a disseminação destas informações?

11. Como é o relacionamento com os demais setores da empresa?

- há espaços para trocas de informações de negócio e experiências?

12. Você participa do processo de tomada de decisões?

- em quais situações?

- de modo formal ou informal? 


\section{APÊNDICE B}

Questões sobre SMVA e a estrutura do mercado brasileiro de telecomunicações Respondentes: representantes das ORMs

1. Você poderia enumerar, em ordem de prioridade, os principais SMVA consumidos no Brasil?

$\begin{array}{ll}\text { ( ) SMS } & (\text { ) ringtones } \\ (\text { ) MMS } & (\text { ) pagamento móvel } \\ (\text { ) música } & (\text { ) banda larga móvel } \\ (\text { ) vídeos } & (\text { ) publicidade móvel } \\ \text { ( ) jogos } & \end{array}$

2. Na sua opinião, o fluxo apresentado abaixo representa a estrutura do mercado de telecomunicações brasileiro?

( ) Sim ( ) Não

Caso não represente, poderia destacar os principais setores do mercado de telecomunicações brasileiro que integram o fluxo de produção/distribuição de SMVA e as porcentagens de faturamento?

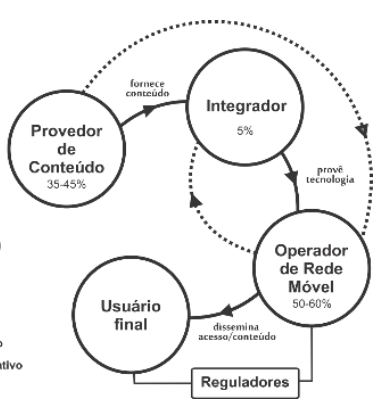

3. Você observa o mercado serviços móveis como um ecossistema? Sua empresa troca informações estratégicas com outros setores do mercado?

4. Quais são as principais diferenças entre a estrutura do mercado de telecomunicações nacional e internacional?

5. Como você observa o papel do integrador no mercado nacional de telecomunicações?

( ) Além da sua importância para a integração operacional, o integrador fornece informação estratégica que influencia na tomada de decisões na minha empresa.

( ) O integrador é importante no mercado devido apenas à sua capacidade de fornecer integração operacional.

( ) O papel do integrador está ameaçado pela possibilidade de conexão direta entre provedores de conteúdo e ORMs de serviços móveis.

( ) Outro: 
6. Que tipo de informação fornecida pelo integrador é mais relevante para seu negócio?

( ) Comportamento dos consumidores

( ) Tendências do mercado

( ) Perfil de tráfego

( ) Faturamento

( ) Melhoria em serviços

( ) Outro:

7. Sua empresa tem investido em inteligência competitiva?
( ) Sim
De que forma?
( ) Não

8. Você poderia enumerar os dados estratégicos relacionados abaixo, de acordo com as prioridades de sua empresa?

( ) Oportunidades de negócio

( ) Ameaças da concorrência

( ) Riscos competitivos

( ) Principais vulnerabilidades

( ) Pressupostos essenciais

( ) Outro:

9. Sua empresa tem investido em gestão do conhecimento?
( ) Sim
Quais são as ações principais?
( ) Não

10. Como você observa os dispositivos com conexão à Internet?

( ) Representam um risco para minha empresa

( ) Representam um risco para a estrutura atual da cadeia produtiva de SMVA

( ) Representam uma possibilidade para novas parcerias e serviços

( ) Outro:

11. Como você observa a entrada das lojas de aplicativos no mercado de telecomunicações?

( ) Representam um risco para minha empresa

( ) Representam um risco para a atual cadeia produtiva de SMVA

( ) Representam um possibilidade para novas parcerias e serviços

( ) Outro: 
12. Quais são os principais desafios do mercado nacional de telecomunicações? E para o mercado internacional?

$\square$ Eu autorizo o uso exclusivo das informações apresentadas neste formulário para o desenvolvimento de pesquisa acadêmica de doutorado, desde que meu nome e o da minha empresa não sejam identificados. 


\section{APÊNDICE C}

Roteiro da entrevista semiestruturada realizada na empresa de implantação e O\&M Respondentes: presidente e o supervisor de treinamentos

1. Quais são os principais serviços prestados?

2. Quais são os principais clientes?

3. A atuação da empresa poderia ser definida como uma atuação basicamente técnica ou há também produção de conhecimento (consultorias, etc.)?

4. Na apresentação da empresa, há uma frase que expressa a necessidade de excelência em gerenciamentos, e não apenas conhecimento técnico, devido a diversidade tecnológica, concorrência, baixo custo e urgência. Poderia explicar?

5. Qual é o perfil profissional de sua equipe?

6. A equipe passa por algum treinamento ao entrar na empresa?

7. Qual seria a demanda por treinamentos corporativos?

8. Quais são as tecnologias utilizadas para comunicação entre as equipes?

9. A empresa atua em todo o território nacional?

10. A empresa conta com sistema de gerenciamento, CSM para controle de supervisão e manutenção, e Sistema de Gerenciamento de Frota. Qual é a finalidade de cada sistema? Esses foram desenvolvidos pela própria empresa?

11. Na apresentação, destaca-se que o foco principal da gestão atual é o controle de custos através de desenvolvimento e uso de ferramentas de TI e Telecom. Este controle refere-se aos custos internos?

12. Como observa a concorrência em relação à área de atuação da empresa?

13. A empresa conta com um setor que observa os movimentos da concorrência e/ou do mercado? Como isso é realizado? 


\section{APÊNDICE D}

Formulário de levantamento de dados e informações aplicado na empresa de implantação e O\&M

Respondentes: gerente de operações e coordenador de RH

Prezado(a), este é um instrumento de pesquisa que visa a levantar dados e informações da empresa, a serem considerados em pesquisa acadêmica com foco em melhoria de processos. Obrigada pela colaboração. Em caso de dúvidas, entre em contato através do e-mail ou telefone.

\section{Perfil dos Colaboradores:}

\begin{tabular}{l} 
Número de $\quad \%$ homens/mulheres: Idade média: \\
colaboradores: \\
\hline Nível médio de escolaridade: \\
\hline Porcentagem de colaboradores que estão estudando (e principais cursos que \\
fazem):
\end{tabular}

Hierarquia na empresa:

Habilidades que precisam ser desenvolvidas:

- Técnicas:

- Comportamentais:

\section{Comunicação:}

- Como é feita a comunicação entre as equipes?

- Os colaboradores apresentam dificuldades no uso de equipamentos de trabalho? Quais?

- A comunicação sobre ocorrências entre o técnico e o colaborador que monitora a alocação da equipe é clara e objetiva? O que poderia ser aprimorado?

- Os colaboradores têm a noção clara de suas funções e de seu papel profissional e social atuando na empresa? Ou seja, entendem a importância de seu trabalho para a empresa e para a sociedade?

- A comunicação via website e intranet é efetiva? O que poderia ser aprimorado? 
- Quais são os principais conteúdos disponibilizados nos canais de comunicação (website, intranet, etc.)?

- Há uma estimativa do número acessos à intranet/mês?

- A empresa já realizou alguma ação de comunicação interna? Como foi?

- A empresa realiza eventos que reúnem todos os colaboradores da empresa ou aqueles que atuam em um mesmo estado?

- Como é feita a comunicação com os fornecedores? Esta comunicação é efetiva?

- Como é feita a comunicação com os clientes? Esta comunicação é efetiva?

- A empresa realiza pesquisa de satisfação com os clientes?

- De modo geral, observa-se prejuízos na produtividade e otimização de tempo por conta de falhas na comunicação? Poderia relacionar alguns?

\section{Treinamento:}

- Frequência anual de treinamentos para novos colaboradores:

- Frequência anual de treinamentos de atualização/reciclagem:

- Frequência anual de treinamentos comportamentais:

- Principais dúvidas levantadas pelos colaboradores nos treinamentos introdutórios:

- Principais dúvidas levantadas pelos colaboradores durante a fase de experiência em campo (quando são acompanhados por um técnico experiente):

- Há avaliação de reação dos treinamentos? Ou seja, há algum espaço para os colaboradores comentarem sobre metodologia utilizada, conteúdo, didática, recursos, ambiente, etc.?

- Os treinamentos têm sido efetivos? Ou seja, os processos/produtividade são aprimorados a cada treinamento ou persistem dúvidas que não se justificariam após os treinamentos?

\section{Perfis Desejados (técnico e comportamental):}

- Quais são as principais competências profissionais técnicas que os colaboradores que irão atuar nos seguintes setores devem ter?

Setor técnico:

Setor gerencial: 
Setor administrativo:

- Quais são as principais deficiências profissionais técnicas identificadas nos colaboradores que atuam nos seguintes setores?

Setor técnico:

Setor gerencial:

Setor administrativo:

- A que atribuem estas deficiências técnicas?

- Quais ações são tomadas pela empresa no sentido de tentar padronizar e aprimorar o perfil técnico dos colaboradores dos seguintes setores?

Setor técnico:

Setor gerencial:

Setor administrativo:

- Quais são as principais competências profissionais comportamentais que os colaboradores que irão atuar nos seguintes setores devem ter?

Setor técnico:

Setor gerencial:

Setor administrativo:

- Quais são as principais deficiências profissionais comportamentais identificadas nos colaboradores que irão atuar nos seguintes setores?

Setor técnico:

Setor gerencial:

Setor administrativo:

- A que atribuem estas deficiências comportamentais?

- Quais ações são tomadas pela empresa no sentido de tentar padronizar e aprimorar o perfil comportamental dos colaboradores dos seguintes setores? Setor técnico:

Setor gerencial:

Setor administrativo:

- Quais estratégias consideram importantes para aprimorar os perfis técnico e comportamental nos próximos treinamentos? 


\section{APÊNDICE E}

Questões sobre serviços de implantação e O\&M

Respondentes: representantes das ORMs

O objetivo deste formulário é coletar informações sobre os serviços prestados por empresas da área de implantação e O\&M de equipamentos de telecomunicações. As informações coletadas serão consideradas, exclusivamente, para a elaboração de tese de doutorado. A proposta é contar com a sua participação, garantindo seu anonimato e o da sua empresa.

1. Qual é a sua expectativa ao contratar uma empresa de implantação e O\&M de equipamentos de telecomunicações?

2. Qual é o fator de decisão na hora de optar por uma empresa da área de infraestrutura de telecomunicações?

3. Quais são as principais ocorrências verificadas em seus equipamentos ou em sua rede?

4. Qual é o impacto gerado pelo atraso na resolução de ocorrências relacionadas aos equipamentos de telecomunicações?

5. Quais são as principais dificuldades encontradas no relacionamento com a empresa que faz a implantação e O\&M de seus equipamentos?

6. Quais são os diferenciais desejados em uma empresa que presta este serviço?

7. Quais são os serviços entregues pela empresa contratada? Há outros serviços, não oferecidos atualmente, que você considera importantes para seu negócio?

8. Além dos dados relacionados às ocorrências, você recebe algum arquivo ou comunicação apresentando informações estratégicas e sugestões de melhorias relacionadas à manutenção de seus equipamentos/serviços? Se não, acharia interessante receber relatórios com informações estratégicas? Que tipo de informação agregaria valor ao seu negócio?

9. Há algum comentário ou sugestão relacionados ao tema abordado neste questionário?

$\square$ Eu autorizo o uso das informações apresentadas neste questionário para a elaboração de tese de doutorado, sem a identificação do meu nome e de minha empresa. 


\section{APÊNDICE F}

Questões sobre serviços de implantação e O\&M

Respondentes: representante do setor comercial da empresa de implantação e O\&M

O objetivo deste formulário é coletar informações sobre a elaboração de propostas de prestação de serviços para as ORMs e sobre as ações de relacionamento com o cliente. As informações coletadas serão consideradas, exclusivamente, para a elaboração de tese de doutorado. A proposta é contar com a sua participação, garantindo seu anonimato e o da sua empresa.

1. O que considera como expectativas das empresas que contratam serviços de implantação e O\&M de equipamentos de telecomunicações?

2. Qual seria o fator de decisão considerado pelas ORMs na hora de optar por uma empresa da área de infraestrutura de telecomunicações?

3. Quais são os principais tipos de ocorrências verificadas nos equipamentos das ORMs clientes?

4. Quais são as médias de tempo previstas para solucionar diferentes tipos de ocorrência? Qual é o impacto gerado pelo atraso na resolução de ocorrências para sua empresa? E para as ORMs?

5. Quais são as principais dificuldades encontradas no relacionamento com as ORMs?

6. Quais são os diferenciais oferecidos às ORMs nas propostas técnicas e comerciais?

7. Quais são os serviços oferecidos atualmente? Há outros serviços, não oferecidos atualmente, que considera importantes para seu negócio e para as ORMs?

8. Além dos dados relacionados às ocorrências, são enviados relatórios ou outro formato de comunicação, apresentando informações estratégicas e sugestões de melhorias relacionadas à manutenção de equipamentos/serviços das ORMs? Se não, acharia interessante e viável enviar relatórios com informações estratégicas? Que tipo de informação agregaria valor ao negócio das ORMs?

9. Qual(is) é(são) a(s) equipe(s) que estabelece $(\mathrm{m})$ relacionamento com as ORMs?

10. Há algum comentário ou sugestão relacionados ao tema abordado?

Eu autorizo o uso das informações apresentadas neste questionário para a elaboração da tese de doutorado, sem a identificação do meu nome e de minha empresa. 


\section{APÊNDICE G}

Termo de consentimento livre e esclarecido assinado pelo CEO e pelos gerentes da integradora estudada

O sr. está sendo convidado a participar, como voluntário, em uma pesquisa, como representante da empresa XXXXX. O estudo de caso será representativo para elaboração de tese de doutorado, com finalidade de divulgação de pesquisa acadêmica, sem objetivo comercial. Após ser esclarecido sobre as informações a seguir, no caso de aceitar fazer parte do estudo, assine ao final deste documento, que está em duas vias.

Informações sobre a pesquisa:

Tema: Estudo de Caso representativo relacionado ao tema Gestão do Conhecimento. Objetivo: Analisar a gestão do conhecimento no mercado de SMVA para geração de vantagem competitiva.

Pesquisadora responsável: Rosângela Spagnol Fedoce

Doutoranda em Engenharia Elétrica

Escola Politécnica da USP

Nome e Assinatura da pesquisadora:

Consentimento da participação da pessoa como sujeito:

$\mathrm{Eu}$, , RG

(cargo na empresa), abaixo assinado, concordo em participar do estudo de caso, como representante da empresa estudada. Fui devidamente informado e esclarecido pela pesquisadora sobre a pesquisa, os procedimentos nela envolvidos, assim como os possíveis riscos e benefícios decorrentes de minha participação. Foi-me garantido que posso retirar meu consentimento a qualquer momento, sem que isto leve a qualquer penalidade.

Local e data , 1

Nome:

Assinatura: 


\section{APÊNDICE H}

Termo de consentimento livre e esclarecido assinado pelo presidente da empresa que atua na implantação e O\&M de equipamentos de telecomunicações

Sua empresa, por meio da participação de gestores e colaboradores, foi convidada a participar de uma pesquisa-ação que integra o processo de coleta de dados e análise da pesquisa de doutorado sobre o tema Gestão do Conhecimento no Setor de Telecomunicações, desenvolvida pela doutoranda Rosângela Spagnol Fedoce. A pesquisa, realizada em sua empresa, será representativa para a elaboração da tese, que tem como finalidade a divulgação de pesquisa acadêmica, sem objetivo comercial. Após ser esclarecido sobre as informações da pesquisa (relacionadas a seguir), em caso de aceite, assine ao final deste documento, que está em duas vias.

Informações sobre a pesquisa:

Tema: Gestão do Conhecimento no Setor de Telecomunicações

Período: 2013-2016

Técnicas utilizadas: entrevistas semiestruturadas, formulários de levantamento de dados e necessidades, observação participante, participação em reuniões de planejamento, produção e validação das ações.

Investigação: levantamento de dados e informações relacionados à necessidade de estruturação de processos de gestão do conhecimento e aprendizagem organizacional.

Ações: desenvolvimento de página online para coleta de informações estratégicas, divulgação de informações institucionais e integração dos colaboradores; criação/ implementação de recursos educacionais em formato online e interativo; desenvolvimento de instrumentos para validação das ações junto aos colaboradores. Pesquisadora responsável:

Rosângela Spagnol Fedoce

Doutoranda em Engenharia Elétrica

Escola Politécnica da USP

Nome e Assinatura da pesquisadora: 
Consentimento da participação da pessoa como sujeito:

Eu, $R G$

(cargo na empresa), abaixo assinado, concordo com a divulgação dos resultados da pesquisa-ação desenvolvida na empresa da qual sou representante. Fui devidamente informado e esclarecido pela pesquisadora sobre os procedimentos de pesquisa, assim como sobre os possíveis riscos e benefícios decorrentes de minha participação. Foi-me garantido o meu anonimato e o da empresa na tese de doutorado e em outras eventuais publicações que derivem da pesquisa.

Local e data

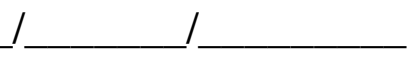

Assinatura: 


\section{APÊNDICE I}

\section{Quadro 1 - Dados qualitativos do estudo realizado com as ORMs}

\begin{tabular}{|c|c|}
\hline Categorias & Síntese das informações coletadas \\
\hline $\begin{array}{l}\text { Capital intelectual } \\
\text { (Cl) }\end{array}$ & $\begin{array}{l}\text { - Conta com área comercial atuando no relacionamento com os parceiros, } \\
\text { área técnica desenvolvendo tecnologia e área de RH e equipe estratégica } \\
\text { focadas em atividades organizacionais. } \\
\text { - Atua com foco nos três pilares do Cl: capital humano, estrutural e } \\
\text { relacional, atribuindo maior ênfase ao capital humano e relacional. } \\
\text { - Seu capital relacional refere-se ao seu foco em faturamento, com relação } \\
\text { de parceria, e não de concorrência, com os demais segmentos do } \\
\text { mercado. } \\
\text { - Conta com sinergia e troca de informações entre as áreas comercial, de } \\
\text { relacionamento com parceiros, departamento jurídico, departamento } \\
\text { financeiro, equipe de integrações, desenvolvimento e projetos. } \\
\text { - Desenvolve ações de aprendizagem organizacional distintas por } \\
\text { localidade de atuação e demandas dos profissionais. }\end{array}$ \\
\hline $\begin{array}{l}\text { Monitoramento } \\
\text { ambiental }\end{array}$ & $\begin{array}{l}\text { - Realiza monitoramento interno e externo diariamente: conversas } \\
\text { informais, informações geradas na plataforma e pesquisas de mercado. } \\
\text { - Tem como principais fontes de informação para o monitoramento os } \\
\text { registros internos e como objetivo principal a superação de desafios } \\
\text { próprios. } \\
\text { - Aplica modelo de visão não direcionada para a observação da } \\
\text { concorrência, que não é agressiva; e modelo de visão condicionada para } \\
\text { monitoramento de perfis de consumidores de determinados produtos. Os } \\
\text { provedores complementam os dados da plataforma, apresentando } \\
\text { informações sobre perfil de usuários, nichos de consumidores e tipos de } \\
\text { mídia. } \\
\text { - Tem como foco das pesquisas mercados internacionais e comportamento } \\
\text { dos consumidores, com objetivo de observar demandas para novos } \\
\text { serviços. } \\
\text { - Utiliza outras fontes de informação, como a Internet e dados da agência } \\
\text { reguladora, uma vez que conta com trânsito livre com as operadoras e } \\
\text { participa do MEF. }\end{array}$ \\
\hline $\begin{array}{l}\text { Inteligência de } \\
\text { Negócios (BI) }\end{array}$ & $\begin{array}{l}\text { - Conta com um Data Warehouse, que faz extrações para atividades de BI, } \\
\text { auxiliando no armazenamento de dados e no monitoramento ambiental. } \\
\text { - Conta com plataformas de BI desenvolvidas, em sua maioria, pela equipe } \\
\text { técnica. } \\
\text { - Gera relatórios customizados: informações necessárias à sua atuação e à } \\
\text { atuação dos demais setores. Exemplo: relatórios apresentando a receita } \\
\text { global por tipo de serviço e o ranking de parceiros. }\end{array}$ \\
\hline $\begin{array}{l}\text { Inteligência } \\
\text { competitiva (IC) }\end{array}$ & $\begin{array}{l}\text { - Conta com uma área de garantia de receita para monitoramento contínuo } \\
\text { dos serviços, cliente a cliente, e geração de comparativos entre } \\
\text { resultados do dia versus resultados anteriores. } \\
\text { - Gera índices de comportamento do mercado: quando os resultados não } \\
\text { se enquadram ao padrão, o sistema aciona um alerta. } \\
\text { - Produz relatórios mensais para os provedores: perfil de tráfego, } \\
\text { faturamento, base de usuários (crescente ou decrescente), necessidade } \\
\text { de investimento em divulgação, etc. } \\
\text { - Desenvolve análises estratégicas: a plataforma gera de } 20 \text { a } 30 \text { milhões } \\
\text { de registros/dia e a análise é necessária para transformá-los em } \\
\text { informações estratégicas para os parceiros. Exemplo: perfil de tráfego do } \\
\text { provedor (usuários pré ou pós-pago, etc.). } \\
\text { - Realiza consultoria, com o objetivo de orientar parceiros ou futuros } \\
\text { parceiros quanto à viabilidade de seus projetos no mercado de telefonia } \\
\text { móvel. }\end{array}$ \\
\hline
\end{tabular}




\section{APÊNDICE J}

Pesquisa de Satisfação aplicada na empresa de implantação e O\&M

Desenvolvida com base nas questões elaboradas pela Fundação Instituto de Administração - FIA (2011), por meio do Programa de Estudos com Gestão de Pessoas (PROGEP), que constitui a pesquisa que define as melhores empresas para se trabalhar no Brasil.

Escala de alternativas: concordo totalmente; concordo; indiferente; discordo; discordo totalmente

Questões:

1. Eu recomendaria a empresa a parentes e amigos, como um excelente lugar para se trabalhar.

2. Reconheço a importância do meu trabalho para a qualidade do serviço prestado e para a construção da imagem da empresa no mercado de telecomunicações.

3. A empresa entrega a seus clientes aquilo que promete, com alta qualidade.

4. Os serviços da empresa são importantes para nossa sociedade.

5. Recebo todas as informações necessárias para fazer bem o meu trabalho.

6. As informações sobre a empresa são transmitidas aos empregados com clareza, rapidez e agilidade.

7. Considero que o tempo que dedico ao meu trabalho é equilibrado entre as necessidades da empresa e as minhas necessidades pessoais e familiares.

8. O volume de trabalho permite que eu termine minhas tarefas no horário previsto.

9. O ambiente de trabalho e os canais de comunicação da empresa facilitam o relacionamento entre os colaboradores.

10. Eu sinto que meu trabalho é importante para que a empresa seja bem-sucedida.

11. Tenho todo o equipamento e o material necessários para realizar bem o meu trabalho.

12. Sou recompensado, de maneira justa, pela qualidade do trabalho que apresento.

13. Trabalhar na empresa reflete segurança e tranquilidade para mim e para minha família.

14. Os processos, procedimentos e rotinas de trabalho são organizados e eficientes.

15. A empresa atende adequadamente às minhas necessidades nas áreas de saúde e outros benefícios. 
16. Quando preciso de outra área da empresa, sou bem atendido.

17. Sinto que minha equipe trabalha como um verdadeiro time.

18. Gostaria de conhecer as equipes e as principais ocorrências nos diversos locais nos quais a empresa atua.

19. A realização profissional pelos desafios superados é a sensação mais frequente que sinto ao sair do trabalho.

20. Sou estimulado a contribuir para melhorar a forma como é feito o meu trabalho.

21. A empresa me estimula a conhecer o trabalho realizado por meus colegas.

22. Acredito que terei a oportunidade de fazer carreira e crescer na empresa.

23. O trabalho que realizo me permite aprender coisas novas sempre.

24. Periodicamente, recebo avaliações sinceras sobre meu desempenho por parte de meu chefe.

25. Meus colegas estão sempre dispostos a compartilhar comigo o que sabem.

26. Os métodos para realizar o trabalho na empresa são frequentemente colocados em discussão.

27. Sinto-me estimulado a buscar novos conhecimentos fora da empresa.

28. Todos têm oportunidade de participar de atividades de treinamento na empresa.

29. Sentiria-me motivado a compartilhar minhas experiências e casos específicos vivenciados na empresa, a fim de ajudar colegas de trabalho que venham a se deparar com a mesma situação.

30. Meu chefe sempre deixa claro o que espera do meu trabalho.

31. Sinto-me livre para contribuir com críticas e sugestões sobre o trabalho para meu chefe.

32. As solicitações e as orientações de minha chefia facilitam a realização do meu trabalho.

33. Meu chefe conhece profundamente sua área de atuação.

34. Que ações a empresa poderia considerar para melhorar a comunicação entre os colaboradores?

35. Quais são suas sugestões e críticas em relação aos treinamentos desenvolvidos pela empresa?

36. O que você espera de sua atuação na empresa em relação à satisfação pessoal e profissional? 
37. Você se sentiria motivado a compartilhar suas experiências de trabalho, a fim de auxiliar outros colaboradores que possam vir a vivenciar ocorrências semelhantes?

38. Quais são as principais vantagens de se trabalhar na empresa?

39. Quais são as principais desvantagens de se trabalhar na empresa?

40. Quais são suas sugestões para que a empresa se consolide como uma excelente empresa para se trabalhar? 


\section{APÊNDICE K}

\section{Quadros com resultados qualitativos da pesquisa de satisfação}

\section{Quadro 2 - Ações que a empresa poderia considerar para melhorar a comunicação entre os colaboradores}

\begin{tabular}{|c|c|}
\hline Categoria & Comentários selecionados \\
\hline $\begin{array}{l}\text { Criar/ utilizar } \\
\text { canais internos }\end{array}$ & $\begin{array}{l}\text { - Não vejo necessidade de melhorias, pois quando preciso me comunicar com } \\
\text { - Naum colaborador sou bem atendida. } \\
\text { portanto, não há o que melhorar. } \\
\text { - Nós, técnicos, é que temos que nos policiar e compartilhar mais. } \\
\text { - Os canais existentes são ferramentas úteis para ampliar a comunicação. } \\
\text { - Divulgar mais os canais de comunicação existentes. } \\
\text { - Creio que este site poderá fazer com que os colaboradores possam interagir } \\
\text { com outras áreas. } \\
\text { - Criar um site com informações direcionadas para orientar e tirar dúvidas sobre } \\
\text { os principais equipamentos da planta. } \\
\text { - Começou bem ao abrir esse portal para, pelo menos, ouvirem nossa opinião, } \\
\text { ouvir se estamos precisando de alguma coisa. } \\
\text { - Ter um portal } 24 h \text { aberto para reclamações e sugestões, com uma equipe que } \\
\text { possa estudar e repassar para resolução. } \\
\text { - Divulgar mais esses canais internos de comunicação. } \\
\text { - Ter um local definido para divulgação das informações, que seja oficial e } \\
\text { centralizado. } \\
\text { - Criar canais de comunicação ou redes sociais para contar a história da } \\
\text { empresa, informando sobre seus contratos, estados/regiões em que possui } \\
\text { filiais, cursos disponíveis no mês, datas comemorativas, calendário do RH (com } \\
\text { informações sobre prazo de entrega de relatórios, solicitação de VR, VR, etc.). } \\
\text { Ou seja, algo que exponha várias informações ao mesmo tempo, seja de fácil } \\
\text { acesso, atrativo para quem o procura, com abas de sugestões (como essa } \\
\text { pesquisa que estamos preenchendo), e que seja diferente do site da empresa, } \\
\text { que é muito resumido e dificilmente atualizado. }\end{array}$ \\
\hline Fazer reuniões & $\begin{array}{l}\text { - Operacionais e gerenciais regulares para traçar metas em conformidade com o } \\
\text { objetivo esperado. } \\
\text { - Sempre que houver mudanças ou eventos que envolvam todo o contrato. } \\
\text { - Via Internet, para discutir dúvidas do trabalho. } \\
\text { - Para debater tarefas executadas e pendências. } \\
\text { - Reunir os profissionais para trocar experiências. } \\
\text { - Para saber quais pontos devemos melhorar. } \\
\text { - Para apresentação e debate dos processos internos, bem como interdisciplinar, } \\
\text { agregando as diversas áreas em que atua. } \\
\text { - Reuniões mensais entre as equipes, mas de maneira em que o colaborador } \\
\text { tenha poder de voz, afinal o técnico é quem está em campo, e não os } \\
\text { coordenadores e superiores. }\end{array}$ \\
\hline $\begin{array}{l}\text { Promover } \\
\text { ações de } \\
\text { integração }\end{array}$ & $\begin{array}{l}\text { - Desenvolver palestras e programa motivacional. } \\
\text { - Criar eventos comemorativos para desenvolver mais relações entre equipes de } \\
\text { campo e administrativas. } \\
\text { - Desenvolver confraternizações em espécie de reunião trimestral com os } \\
\text { gerentes de projeto, envolvendo coordenadores supervisão e facilitadores, para } \\
\text { debate de metas e correção de processos e/ou ações em eventos críticos na } \\
\text { busca pela satisfação dos clientes e melhorias com excelência em serviços } \\
\text { prestados. } \\
\text { - Proporcionar e incentivar prática de esportes coletivos. } \\
\text { - Realizar ações sociais e competições entre setores. }\end{array}$ \\
\hline
\end{tabular}




\begin{tabular}{|c|c|}
\hline & $\begin{array}{l}\text { - Apresentar novos colaboradores. } \\
\text { - Melhorar a integração de novos colaboradores, divulgando e-mail, telefone etc. } \\
\text { - Criar palestras/eventos motivacionais em momentos pontuais, como fusões, } \\
\text { ampliação da empresa e, até mesmo, início de ano, pois esses funcionariam } \\
\text { como um "plus" na hora de motivar seus colaboradores a crescer ou focar em } \\
\text { um projeto. }\end{array}$ \\
\hline $\begin{array}{l}\text { Divulgar } \\
\text { notícias } \\
\text { internas }\end{array}$ & $\begin{array}{l}\text { - Divulgar os principais acontecimentos internos da empresa. } \\
\text { - Acesso à informação não só para cargos hierárquicos, mas também ao } \\
\text { colaborador final. } \\
\text { - Maior clareza sobre a situação da empresa, pois fico sabendo por terceiros } \\
\text { - Hobre as mudanças que ocorrem. } \\
\text { - Há assuntos que devem chegar aos colaboradores, mas ficam retidos entre } \\
\text { - Coordenadores e gerentes. } \\
\text { estagnação na empresa. }\end{array}$ \\
\hline $\begin{array}{l}\text { Promover } \\
\text { diálogo com } \\
\text { gerência }\end{array}$ & $\begin{array}{l}\text { - Maior proximidade do gerente com sua equipe, atualizando mudanças e } \\
\text { novidades. } \\
\text { - Criar chat para facilitar a comunicação entre técnicos e coordenadores das } \\
\text { regiões. } \\
\text { - Colocar, nos cargos de chefia e coordenação, pessoas que realmente sejam } \\
\text { capacitadas a liderar, facilitar e orientar sua equipe, e não chefes que } \\
\text { desestimulam, desorganizam e dividem a equipe. } \\
\text { - líder tem que ser parte do time da execução, se comprometendo com o seu } \\
\text { plano de comunicação com os colaboradores e proporcionando liberdade de } \\
\text { expressão aos colaboradores. }\end{array}$ \\
\hline $\begin{array}{l}\text { Promover } \\
\text { colaboração }\end{array}$ & $\begin{array}{l}\text { - Permitir o acompanhamento de técnicos em atividades em outras regiões, para } \\
\text { conhecer e manusear diferentes equipamentos. } \\
\text { - Promover visitas de um setor no outro para conhecimento dos processos. } \\
\text { - Poderia haver mais troca de informações entre todos colaboradores, facilitaria } \\
\text { muito o trabalho. } \\
\text { - Criar fórum de debate sobre nossos problemas em campo no dia a dia. } \\
\text { - O fórum atual facilita a comunicação e a solução de dúvidas - precisamos criar } \\
\text { o hábito de utilizar estes meios de comunicação. }\end{array}$ \\
\hline $\begin{array}{l}\text { Desenvolver } \\
\text { cursos }\end{array}$ & $\begin{array}{l}\text { - Criar cursos sobre comunicação corporativa e comportamento organizacional. } \\
\text { - Investir em treinamento sobre novas tecnologias, pois, a cada dia, entram } \\
\text { novos equipamentos na planta e não estamos dominando os mesmos. } \\
\text { - Criar cursos específicos sobre liderança. }\end{array}$ \\
\hline $\begin{array}{l}\text { Explorar } \\
\text { comunicação } \\
\text { via celular }\end{array}$ & $\begin{array}{l}\text { - Celulares de operadoras diferentes dificultam a comunicação entre colegas. } \\
\text { - Liberar os meios de comunicação via Internet no celular. } \\
\text { - Não enviar ordem de serviço apenas por e-mail, mas, também, por meio de } \\
\text { outros canais, como mensagens de texto ou mesmo chamadas, pois não } \\
\text { estamos conectados à Internet o tempo todo. } \\
\text { - Desenvolver aplicativo para conversas online. } \\
\text { - Estamos numa fase tecnológica na qual contamos com dispositivos como } \\
\text { celulares e softwares com muito recursos que poderiam ser direcionados à } \\
\text { área técnica e operacional. }\end{array}$ \\
\hline $\begin{array}{l}\text { Desenvolver } \\
\text { feedback/ plano } \\
\text { de carreira }\end{array}$ & $\begin{array}{l}\text { - Promover feedback com os colaboradores a cada mês. } \\
\text { - Desenvolver campanhas com prêmios e folgas extras para colaboradores que } \\
\text { se destacarem. } \\
\text { - Criar conferências com os colaboradores de cada estado para avaliação do } \\
\text { rendimento da semana e troca de experiências. } \\
\text { - Apresentar um plano de carreira a todos os profissionais. } \\
\text { - Dar mais oportunidades aos que estão colaborando com o processo de } \\
\text { crescimento da empresa há mais tempo. }\end{array}$ \\
\hline $\begin{array}{l}\text { Padronizar } \\
\text { processos }\end{array}$ & $\begin{array}{l}\text { - Deixar mais claro a metodologia e a sistemática de trabalho de cada setor. } \\
\text { - Elaborar procedimentos bem definidos no estilo POP (Procedimento } \\
\text { Operacional Padrão). }\end{array}$ \\
\hline
\end{tabular}




\begin{tabular}{|l|l|}
\hline & $\begin{array}{l}\text { - Temos a sensação de cada filial da empresa trabalha de uma maneira diferente } \\
\text { da outra. }\end{array}$ \\
\hline & $\begin{array}{l}\text { - Atuar de forma clara, a fim de divulgar todos os procedimentos e mudanças da } \\
\text { empresa. }\end{array}$ \\
Promover RH & $\begin{array}{l}\text { Criar um sistema de comunicação mais eficaz entre RH e empresa. } \\
\text { mais atuante } \text { Deveria usar mais o e-mail para comunicados importantes a respeito de todos. } \\
\text { - RH mais atuante, trazendo novidades, campanhas, etc. } \\
\text { - Age muito pouco, poderia divulgar jornais impressos, boletins informativos, etc. }\end{array}$ \\
\hline
\end{tabular}

Fonte: Autora.

\section{Quadro 3 - Sugestões e críticas em relação aos treinamentos desenvolvidos pela empresa}

\begin{tabular}{|c|c|}
\hline Categoria & Comentários selecionados \\
\hline $\begin{array}{l}\text { Desenvolver } \\
\text { mais } \\
\text { treinamentos }\end{array}$ & $\begin{array}{l}\text { - Desenvolver programa de treinamento a cada } 6 \text { meses, EAD ou presencial, da } \\
\text { empresa ou de um fabricante. } \\
\text { - Investir em treinamento técnico: nosso pessoal tem baixa qualificação técnica } \\
\text { e isso reflete na nossa imagem junto ao cliente. } \\
\text { - Treinamento para os projetos de infraestrutura. } \\
\text { - No momento, na área em que atuo, não há treinamento, mas gostaria muito } \\
\text { que houvesse. } \\
\text { - Mais treinamentos para o setor administrativo. } \\
\text { - Treinamentos na integração de novos colaboradores. } \\
\text { - O mercado e a tecnologia estão sempre à frente e não temos treinamento. } \\
\text { - Temas para novos treinamentos: gestão e liderança; centrais NGN; brigada de } \\
\text { incêndios; NR17; cursos na área de transmissão; DO N1; Rádio NEC, MUX; } \\
\text { infra (fontes, climatização); Excel; gestão de pessoas; IDU, NODEB; } \\
\text { comunicação assertiva e liderança; refrigeração; Rádio IP, tellabs e DWDM; } \\
\text { Radio, Erickson, Huawei. } \\
\text { - Organizar cursos diretamente com os fabricantes. }\end{array}$ \\
\hline $\begin{array}{l}\text { Manter } \\
\text { qualidade }\end{array}$ & $\begin{array}{l}\text { - Os treinamentos são bons, capacitam o colaborador para o trabalho do dia a } \\
\text { dia. } \\
\text { - Tenho visto uma equipe comprometida em melhorar os processos de ensino e } \\
\text { transmissão de conhecimento dentro da empresa. } \\
\text { - Estive presente em apenas um treinamento ao longo de um ano e todas minhas } \\
\text { dúvidas até hoje foram sanadas por supervisores e coordenadores de minha } \\
\text { regional, sempre estive cercado por excelentes profissionais que sempre } \\
\text { estiveram dispostos a me ajudar, porém, ainda acho que, se houvesse uma } \\
\text { consulta sobre as dificuldades de campo, os treinamentos seriam mais } \\
\text { eficientes. } \\
\text { - Ótima qualidade e bons instrutores. } \\
\text { - O cadastro de colaboradores no site interno, para saber seu nível de } \\
\text { conhecimento, é um bom caminho. }\end{array}$ \\
\hline $\begin{array}{l}\text { Não tive } \\
\text { treinamento }\end{array}$ & $\begin{array}{l}\text { - Não tive treinamento, somente me sentei ao lado de um operador e visualizei o } \\
\text { atendimento, o que é muito precário, pois para aprender no atendimento tem } \\
\text { que haver recebimento por parte dos supervisores, comunicação para ensinar } \\
\text { e material para tirar dúvidas. } \\
\text { - Estou na empresa há } 1 \text { ano e } 4 \text { meses e nunca fiz treinamento. } \\
\text { - } 5 \text { anos de empresa e nunca realizei treinamento. }\end{array}$ \\
\hline $\begin{array}{l}\text { Desenvolver } \\
\text { treinamentos } \\
\text { mais práticos }\end{array}$ & $\begin{array}{l}\text { - Desenvolver treinamentos mais práticos e menos teóricos. } \\
\text { - Mais em campo e menos em sala de aula. } \\
\text { - Após treinamento teórico, acho que deve se fazer treinamento em campo com } \\
\text { a equipe experiente de manutenção, para evitar acidentes e incidentes no } \\
\text { trabalho. }\end{array}$ \\
\hline $\begin{array}{l}\text { Criar mais } \\
\text { cursos online }\end{array}$ & - Investir em treinamentos EAD. \\
\hline
\end{tabular}




\begin{tabular}{|c|c|}
\hline & $\begin{array}{l}\text { - Gostei muito de alguns treinamentos online, pois tiveram a mesma eficiência } \\
\text { que os presenciais, me possibilitando continuar trabalhando na minha região, } \\
\text { sem me afastar do trabalho e da minha família. } \\
\text { - Acredito que poderemos ter algo muito efetivo, caso consigamos sedimentar o } \\
\text { EAD. } \\
\text { - Estou muito satisfeito com a forma como estão acontecendo os cursos e } \\
\text { treinamentos, mas acredito que, quando for a opção de curso a distância, seria } \\
\text { melhor conversar primeiro com a coordenação, pois, neste último curso, não fui } \\
\text { informado em nenhum momento sobre o horário que eu poderia destinar ao } \\
\text { estudo. }\end{array}$ \\
\hline $\begin{array}{l}\text { Desenvolver } \\
\text { treinamentos } \\
\text { mais frequentes }\end{array}$ & $\begin{array}{l}\text { - Temos equipamentos novos entrando na planta todos os anos, e não temos } \\
\text { treinamentos. Aprendemos na marra em campo e na correria. } \\
\text { - São muito vagos e distantes, por isso, seria importante ter uma rotina de } \\
\text { desenvolvimento e proximidade com o operacional. } \\
\text { - Não há reciclagem periódica, quando os equipamentos novos chegam na } \\
\text { planta, temos que bater muita cabeça e ir atrás de informações. }\end{array}$ \\
\hline $\begin{array}{l}\text { Ampliar acesso } \\
\text { aos } \\
\text { treinamentos }\end{array}$ & $\begin{array}{l}\text { - Que todos os colaboradores, de todas as regiões, possam participar por igual } \\
\text { dos treinamentos oferecidos não somente pela empresa como também pelos } \\
\text { clientes. } \\
\text { - Não há treinamentos para o administrativo, o que seria importante para o } \\
\text { desenvolvimento interno. }\end{array}$ \\
\hline $\begin{array}{l}\text { Criar mais } \\
\text { cursos } \\
\text { presenciais }\end{array}$ & $\begin{array}{l}\text { - Cursos presenciais seriam mais válidos. } \\
\text { - Treinar os colaboradores em suas próprias cidades de atuação ou o mais perto } \\
\text { possível. } \\
\text { - Em relação ao NR10, deveria ser feito com a presença de profissionais } \\
\text { qualificados, e não por Internet. }\end{array}$ \\
\hline $\begin{array}{l}\text { Criar apoio para } \\
\text { formação } \\
\text { complementar }\end{array}$ & $\begin{array}{l}\text { - A empresa poderia dar uma ajuda de custo para que o técnico faça cursos na } \\
\text { área em que atua. } \\
\text { - Fazer convênios com faculdades e escolas, oferecendo descontos aos } \\
\text { colaboradores. }\end{array}$ \\
\hline Integrar equipes & $\begin{array}{l}\text { - Desenvolver seminários com equipes de diferentes estados do Brasil, que } \\
\text { atuam na mesma área (gerências, coordenações e pessoal interno), para troca } \\
\text { de experiências e diferenciação entre as atuações em cada UF. } \\
\text { - Realizar treinamentos, mesclando técnicos de regionais diferentes, trazendo } \\
\text { mais parceria entre esses e disseminando experiências. }\end{array}$ \\
\hline $\begin{array}{l}\text { Formar tutores/ } \\
\text { multiplicadores }\end{array}$ & $\begin{array}{l}\text { - Aproveitar melhor o conhecimento e a vivência das equipes de campo, } \\
\text { utilizando o próprio colaborador como palestrante. } \\
\text { - Treinar uma pessoa que conheça muito bem o assunto para que a mesma } \\
\text { repasse o treinamento em sua região. }\end{array}$ \\
\hline $\begin{array}{l}\text { Desenvolver } \\
\text { mais recursos } \\
\text { educacionais }\end{array}$ & $\begin{array}{l}\text { - Material didático abrangente e completo, ressaltando os pontos mais } \\
\text { importantes dos cursos. }\end{array}$ \\
\hline $\begin{array}{l}\text { Padronizar } \\
\text { processos }\end{array}$ & $\begin{array}{l}\text { - Fiz somente um treinamento em } 4 \text { anos de empresa e não há um padrão de } \\
\text { trabalho, um sistema que tenha começo, meio e fim, e nem onde procurar, } \\
\text { como um site ou material impresso, somente ligando para outras pessoas e } \\
\text { perguntando. }\end{array}$ \\
\hline $\begin{array}{l}\text { Divulgar os } \\
\text { cursos }\end{array}$ & $\begin{array}{l}\text { - Nomear um CQ (controle de qualidade) em todas as bases, a fim de } \\
\text { divulgarmos melhor os cursos e treinamentos oferecidos. }\end{array}$ \\
\hline $\begin{array}{l}\text { Identificar } \\
\text { colaboradores } \\
\text { interessados }\end{array}$ & - Identificar colaboradores interessados a participar dos treinamentos. \\
\hline
\end{tabular}

Fonte: Autora. 
Quadro 4 - O que você espera de sua atuação na empresa em relação à satisfação

\section{pessoal e profissional}

\begin{tabular}{|c|c|}
\hline Categoria & Comentários selecionados \\
\hline $\begin{array}{l}\text { Crescer pessoal/ } \\
\text { profissionalmente }\end{array}$ & $\begin{array}{l}\text { - Continuar crescendo e aprendendo junto com a empresa. } \\
\text { - Espero evoluir profissionalmente dentro da mesma, pois minha formação em } \\
\text { Telecom me mostrou que a área tem ramificado por vários setores e, no } \\
\text { mundo atual, é preciso estar sempre em evolução, tanto pessoal como } \\
\text { profissionalmente. } \\
\text { - Equilibrar trabalho x família: entendo que, à medida que conseguir equilibrar a } \\
\text { carga de trabalho com a atenção familiar, terei grande nível de satisfação. }\end{array}$ \\
\hline Ser reconhecido & $\begin{array}{l}\text { - Reconhecimento financeiro e funcional. } \\
\text { - Minha satisfação pessoal seria ver meu trabalho e meu esforço reconhecidos. } \\
\text { - Eaber que tem alguém me olhando, me orientando, me ajudando a melhorar. } \\
\text { para o sucesso do projeto, por parte dos gestores, para motivar cada vez mais } \\
\text { suas equipes. } \\
\text { - Desempenhar o meu trabalho de forma satisfatória e ter o reconhecimento por } \\
\text { isso, seja com um elogio ou com uma melhoria salarial. } \\
\text { - Receber avaliações sinceras sobre o meu desempenho. } \\
\text { - Meritocracia. }\end{array}$ \\
\hline $\begin{array}{l}\text { Contribuir com } \\
\text { trabalho }\end{array}$ & $\begin{array}{l}\text { - Atender às exigências dentro da minha função. } \\
\text { - Ser o mais proativo possível. } \\
\text { - Trabalhar com bastante transparência e profissionalismo para alcançar } \\
\text { projeção. } \\
\text { - Desempenhar minhas funções da melhor maneira, contribuindo para o } \\
\text { crescimento da empresa. }\end{array}$ \\
\hline $\begin{array}{l}\text { Agregar } \\
\text { conhecimento }\end{array}$ & $\begin{array}{l}\text { - Estou estudando para buscar mais conhecimento e reconhecimento na área } \\
\text { de atuação. } \\
\text { - Aprender mais a ter o conhecimento total da função que exerço. } \\
\text { - Ampliar o conhecimento profissional, desenvolver ferramentas para evitar } \\
\text { retrabalho e me tornar uma pessoa útil à equipe e realizada pessoalmente. } \\
\text { - Fazer pós-graduação. } \\
\text { - Contar com mais treinamentos, workshops e palestras, para que eu possa me } \\
\text { manter atualizado, entregando melhor qualidade de trabalho às equipes. }\end{array}$ \\
\hline $\begin{array}{l}\text { Trabalhar em } \\
\text { equipe }\end{array}$ & $\begin{array}{l}\text { - Corresponder com quem trabalha no meu grupo, no sentido de } \\
\text { companheirismo, liberdade e trabalho em grupo. } \\
\text { - Proporcionar a ajuda necessária aos meus colegas e atender às expectativas } \\
\text { dos meus superiores. } \\
\text { - Conquistar respeito dos meus colegas de trabalho e contar com nova postura } \\
\text { dos supervisores no tratamento dos subordinados, como falar e dar um } \\
\text { feedback. } \\
\text { - Que eu tenha um ambiente saudável para realizar minhas atividades e } \\
\text { desenvolver e ampliar meus conhecimentos, cercado por profissionais com o } \\
\text { mesmo intuito. } \\
\text { - Continuar tendo bom relacionamento com os colegas de trabalho e recebendo } \\
\text { suporte para que possa realizar todas atividades com disposição e eficiência. }\end{array}$ \\
\hline Alcançar metas & $\begin{array}{l}\text { - Espero atingir os objetivos e metas acordados com a empresa. } \\
\text { - Contribuir para o alcance das metas da empresa, para que ela mantenha sua } \\
\text { saúde financeira e, assim, gere oportunidades de crescimento profissional } \\
\text { interno. }\end{array}$ \\
\hline $\begin{array}{l}\text { Satisfazer } \\
\text { clientes }\end{array}$ & $\begin{array}{l}\text { - Fazer o melhor para satisfazer o cliente e, dessa forma, contribuir para a } \\
\text { valorização da empresa como prestadora de serviços em Telecom. } \\
\text { - Sempre focar no cliente, atendendo de forma rápida, de maneira que eu me } \\
\text { torne imprescindível para a empresa. }\end{array}$ \\
\hline
\end{tabular}




\begin{tabular}{|l|l|}
\hline Agregar valor & $\begin{array}{l}\text { Espero poder agregar valor para a companhia, gerando receita e perenidade } \\
\text { para a mesma e, em contrapartida, gerando valor e conhecimento para a } \\
\text { minha carreira profissional. } \\
\text { - Com a determinação e o conhecimento que trago na bagagem, espero somar } \\
\text { ao crescimento da empresa, porém, para isso, é preciso que a coordenação } \\
\text { ou a supervisão ouçam um pouco mais nossas opiniões. }\end{array}$ \\
\hline $\begin{array}{l}\text { Sem } \\
\text { perspectivas }\end{array}$ & $\begin{array}{l}\text { Ná há perspectiva de crescimento profissional, acadêmico ou financeiro. Não } \\
\text { há plano carreira, aperfeiçoamento e valorização de grau de estudo. }\end{array}$ \\
\hline
\end{tabular}

Fonte: Autora.

\section{Quadro 5 - Motivação para a compartilhar suas experiências de trabalho}

\begin{tabular}{|c|c|}
\hline Categoria & Comentários selecionados \\
\hline Motivado & $\begin{array}{l}\text { - Sim, desde que isso torne-se uma cultura e que tenha valor. } \\
\text { - Há } 2 \text { anos sempre que me deparo com uma situação nova, faço material e } \\
\text { repasso aos colegas, porém não existe reciprocidade, além de } \\
\text { reconhecimento, seja financeiro ou de função na empresa. } \\
\text { - Isso já acontece na regional, um ajudando o outro. } \\
\text { - Sempre que posso, envio e-mail ao meu chefe para informar e auxiliar novas } \\
\text { descobertas referentes ao serviço prestado. } \\
\text { - No nosso grupo, sempre trocamos informação sobre defeitos em } \\
\text { equipamentos e manuseio dos mesmos, tanto de comunicação, climatização, } \\
\text { sinalização, elétrica etc. } \\
\text { - Com toda certeza, pois estou sendo muito bem auxiliado por meus parceiros } \\
\text { de trabalho. } \\
\text { - Não só me sinto motivado, como sempre atuei e atuo desta forma, pois } \\
\text { acredito que somente repassando conhecimentos e recebendo } \\
\text { conhecimentos alheios é que poderemos construir uma empresa sólida e de } \\
\text { sucesso no mercado. } \\
\text { - O compartilhamento de experiências agrega não só conhecimento como } \\
\text { também estabelece um vínculo de confiança entre a equipe. } \\
\text { - Sim; e a participação em fóruns sobre atividades me parece uma boa iniciativa } \\
\text { para difundir o conhecimento e unificar a linguagem dos técnicos nas diversas } \\
\text { regiões. }\end{array}$ \\
\hline Não motivado & $\begin{array}{l}\text { - Não, porque temos várias resistências de pessoas que trabalham há anos e } \\
\text { não estão dispostas a se colocar à disposição para novos desafios. }\end{array}$ \\
\hline
\end{tabular}

Fonte: Autora.

Quadro 6 - Principais vantagens de se trabalhar na empresa

\begin{tabular}{|l|l|}
\hline Categoria & Comentários selecionados \\
\hline \multirow{1}{*}{ Empresa sólida } & $\begin{array}{l}\text { - Referência neste ramo de atuação. } \\
\text { - Organização idônea e que está sempre se adequando aos requisitos do } \\
\text { mercado. } \\
\text { - Segurança de uma empresa sólida. } \\
\text { - Ótima qualidade: muitos anos no mercado, auxilia de forma clara minhas } \\
\text { funções e distribui os serviços adequadamente. } \\
\text { - Empresa bem-sucedida na área de telecomunicações e de grande } \\
\text { abrangência nacional. } \\
\text { - Obedece a todas as regras vigentes pela lei. } \\
\text { - Empresa sólida, que atua em diversos segmentos, com perspectiva de } \\
\text { ampliação. } \\
\text { - Comprometida com as leis trabalhistas. } \\
\text { - Fazer parte de uma empresa preocupada com a eficiência de seu serviço } \\
\text { leva os colaboradores a buscarem a perfeição. } \\
\text { - Grande conhecimento na área de atuação. }\end{array}$ \\
\hline Bons benefícios & $\begin{array}{l}\text { - O plano de saúde me tranquiliza, me deixa seguro e despreocupado para } \\
\text { me dedicar ao trabalho. }\end{array}$ \\
\hline
\end{tabular}




\begin{tabular}{|c|c|}
\hline & $\begin{array}{l}\text { - Plano odontológico. } \\
\text { - Transporte. } \\
\text { - Telefonia. }\end{array}$ \\
\hline $\begin{array}{l}\text { Remuneração } \\
\text { adequada }\end{array}$ & $\begin{array}{l}\text { - De acordo com a média do mercado. } \\
\text { - Pontualidade. } \\
\text { - Segurança financeira. }\end{array}$ \\
\hline $\begin{array}{l}\text { Possibilidade de } \\
\text { agregar } \\
\text { conhecimento }\end{array}$ & $\begin{array}{l}\text { - Possibilidade de adquirir conhecimento tecnológico. } \\
\text { - Novos desafios do dia a dia, proporcionando novos conhecimentos. } \\
\text { - A flexibilidade e as novidades tecnológicas as quais nos deparamos } \\
\text { diariamente fazem-nos descobrir soluções novas para os velhos problemas. }\end{array}$ \\
\hline $\begin{array}{l}\text { Ambiente de } \\
\text { trabalho agradável }\end{array}$ & $\begin{array}{l}\text { - Agradável. } \\
\text { - Sempre poder interagir com as pessoas, fazendo com que se abram vários } \\
\text { leques de amizade e conhecimento. }\end{array}$ \\
\hline $\begin{array}{l}\text { Possibilidade de } \\
\text { crescimento } \\
\text { pessoal/profissional }\end{array}$ & $\begin{array}{l}\text { - Boas expectativas profissionais. } \\
\text { - Realização profissional. }\end{array}$ \\
\hline $\begin{array}{l}\text { Trabalho em } \\
\text { equipe satisfatório }\end{array}$ & $\begin{array}{l}\text { - De alta qualidade. } \\
\text { - União e interação entre os colaboradores. } \\
\text { - Fazer parte de um time vencedor nos mantêm sempre motivados. } \\
\text { - Colegas dispostos a ajudar. } \\
\text { - Satisfação de fazer parte de um time que pensa em conquistas, de ser } \\
\text { respeitado e de ser compensado, saber que estou em uma empresa } \\
\text { organizada estruturalmente com qualidade. }\end{array}$ \\
\hline $\begin{array}{l}\text { Interação com a } \\
\text { gerência }\end{array}$ & $\begin{array}{l}\text { - Canal de comunicação direto com supervisor, coordenador e gerente, } \\
\text { facilitando a resolução dos problemas. } \\
\text { - Gosto do modo como os líderes interagem com os colaboradores, não são } \\
\text { "opressores", nos dizem o que querem de uma forma cortês e educada e eu } \\
\text { procuro atender sempre. }\end{array}$ \\
\hline Reconhecimento & $\begin{array}{l}\text { - A empresa e seus clientes dão valor às pessoas que fazem o seu trabalho } \\
\text { se destacar. } \\
\text { - O respeito com que os colaboradores são tratados demonstra o quanto são } \\
\text { importantes para a empresa. } \\
\text { - Permite ao colaborador sentir-se real membro da empresa. }\end{array}$ \\
\hline Trabalho motivador & $\begin{array}{l}\text { - Conhecer uma planta grande e as variações de uso de múltiplas tecnologias. } \\
\text { - Atuar na área de tecnologia avançada. } \\
\text { - Ter sempre algo novo para ser executado. } \\
\text { - Trabalhar no que gosto. } \\
\text { - Novos desafios todos os dias. }\end{array}$ \\
\hline Estabilidade & - Segurança. \\
\hline $\begin{array}{l}\text { Ferramentas/ } \\
\text { recursos } \\
\text { adequados }\end{array}$ & - Oferece todas as necessárias: carro, notebook, smartphone, etc. \\
\hline $\begin{array}{l}\text { Carga horária } \\
\text { adequada }\end{array}$ & $\begin{array}{l}\text { - Horário flexível. } \\
\text { - Permite trabalhar e estudar. } \\
\text { - Escala de plantão correta. }\end{array}$ \\
\hline $\begin{array}{l}\text { Compromisso com } \\
\text { o colaborador }\end{array}$ & - Comprometimento com o colaborador. \\
\hline Autonomia & $\begin{array}{l}\text { - Tenho um pouco mais de liberdade para tomar decisões relacionadas às } \\
\text { minhas tarefas do que em outras empresas onde trabalhei. } \\
\text { - Flexibilidade para assuntos pessoais. }\end{array}$ \\
\hline
\end{tabular}

Fonte: Autora. 
Quadro 7 - Principais desvantagens de se trabalhar na empresa

\begin{tabular}{|c|c|}
\hline Categoria & Comentários selecionados \\
\hline $\begin{array}{l}\text { Carga horária } \\
\text { excessiva }\end{array}$ & $\begin{array}{l}\text { - Acionamentos em horários diversos, fora do horário comercial. } \\
\text { - Pouco tempo com a família. } \\
\text { - Trabalhar para mais de uma operadora ao mesmo tempo. } \\
\text { - Não estou conseguindo cursar minha pós-graduação, pois todos os dias tenho } \\
\text { muito trabalho fora do horário. } \\
\text { - A escala atual, que nos tirou dois finais de semana no mês, poderia ser } \\
\text { repensada. } \\
\text { - O fato de não existir horas extras, e sim banco de horas, desmotiva alguns } \\
\text { colaboradores. }\end{array}$ \\
\hline Gestão ineficiente & $\begin{array}{l}\text { - Necessidade de mudança de algumas culturas de gerenciamento. } \\
\text { - Dificuldade em resolver problemas de bem comum, quando expostos aos } \\
\text { chefes. } \\
\text { - Temos um chefe "dificultador", e não um facilitador; a empresa deveria ser } \\
\text { mais criteriosa na escolha de supervisores e coordenadores, os quais, na } \\
\text { maioria das vezes, nem sabem suas funções, seus posicionamentos e ações, } \\
\text { sendo retrógrados, inseguros e radicais. } \\
\text { - A empresa é boa, mas a gestão da região não dá incentivo algum para o } \\
\text { colaborador. } \\
\text { - Não cumprimento dos procedimentos criados pela empresa pelos gestores. } \\
\text { - Chefia desorganizada para liderar nossas tarefas. } \\
\text { - Falta de respeito dos gestores com o profissional de campo. } \\
\text { - Suporte muito deficiente dos departamentos centralizados (TI, RH, Frotas, } \\
\text { etc.). }\end{array}$ \\
\hline $\begin{array}{l}\text { Remuneração } \\
\text { inadequada }\end{array}$ & $\begin{array}{l}\text { - Teria que ter uma remuneração mais equilibrada, com relação às mesmas } \\
\text { atividades realizadas. } \\
\text { - Poderia ser um pouco melhor, respeitando o nível técnico de cada um. }\end{array}$ \\
\hline $\begin{array}{l}\text { Ausência de } \\
\text { feedback/ plano } \\
\text { de carreira }\end{array}$ & $\begin{array}{l}\text { - Não tem avaliação de cargos e salários, nem avaliação por competência. } \\
\text { - Falta de avaliação de desempenho para verificação se as pessoas são as } \\
\text { melhores para aquela função. }\end{array}$ \\
\hline $\begin{array}{l}\text { Poucos } \\
\text { benefícios }\end{array}$ & $\begin{array}{l}\text { - Desorganização para depositar vale transporte. } \\
\text { - Não ter PLR. } \\
\text { - Falta de auxílio combustível. } \\
\text { - Falta de incentivo aos estudos. } \\
\text { - Não pagamento de periculosidade. }\end{array}$ \\
\hline $\begin{array}{l}\text { Estrutura } \\
\text { organizacional } \\
\text { ineficiente }\end{array}$ & $\begin{array}{l}\text { - Processos básicos não definidos. } \\
\text { - Os cargos/funções não são atualizados conforme a atividade exercida pelo } \\
\text { - Colaborador. } \\
\text { - Como temos vários setores e contratos, teríamos que ter uma maior interação } \\
\text { - Logístrica de trabalho que deixa muito desejar. } \\
\text { - Almoxarifado lento e de acesso complicado. } \\
\text { - Falta de planejamento para as mudanças, que acontecem de forma muito } \\
\text { rápida. } \\
\text { - Pouco tempo para estudar a atividade a ser realizada. } \\
\text { - Falta de apoio técnico para a solução de problemas. }\end{array}$ \\
\hline $\begin{array}{l}\text { Falta de } \\
\text { treinamento/ } \\
\text { desenvolvimento }\end{array}$ & $\begin{array}{l}\text { - Falta treinamento: a maioria do conhecimento é empírico, vivencial através } \\
\text { de erros e acertos. } \\
\text { - Sempre fazemos a mesma coisa e não temos treinamentos para aperfeiçoar } \\
\text { o que já aprendemos com os colegas de trabalho e para aprender mais para } \\
\text { ajudar a empresa a crescer. } \\
\text { - Não há oportunidades para compartilhar conhecimentos. }\end{array}$ \\
\hline Distância/viagens & $\begin{array}{l}\text { - Distâncias percorridas: é chato passar tanto tempo longe da família. } \\
\text { - Distância em relação à sede da empresa: muitas coisas, como exames de } \\
\text { saúde periódicos, poderiam ser feitas na cidade onde trabalho. }\end{array}$ \\
\hline
\end{tabular}




\begin{tabular}{|c|c|}
\hline $\begin{array}{l}\text { Comunicação } \\
\text { ineficaz }\end{array}$ & $\begin{array}{l}\text { - Diversos setores/projetos não se conversam, transformando a empresa em } \\
\text { "diversas ilhas". } \\
\text { - A informação, muitas vezes, não chega: ficamos sabendo de alguma } \\
\text { mudança de procedimento quando estamos atuando. } \\
\text { - Falta comunicação sobre as oportunidades internas. } \\
\text { - Algumas áreas dentro da própria empresa não se conversam, parecem ser } \\
\text { concorrentes e isso gera conflitos internos desnecessários. }\end{array}$ \\
\hline $\begin{array}{l}\text { Ferramentas/ } \\
\text { recursos } \\
\text { inadequados }\end{array}$ & $\begin{array}{l}\text { - Falta equipamentos e ferramentas. } \\
\text { - Valor baixo de aluguel de carro particular. } \\
\text { - Como trabalho na região nordeste do Brasil, acho que poderíamos utilizar } \\
\text { carros climatizados, camisas e bonés com proteção UVA/UVB. } \\
\text { - Os veículos, em sua maioria, são básicos demais para nós técnicos que } \\
\text { passamos boa parte do tempo viajando. }\end{array}$ \\
\hline $\begin{array}{l}\text { Falta de } \\
\text { reconhecimento }\end{array}$ & $\begin{array}{l}\text { - Reconhecimento salarial, pois a diferença entre quem tem CREA e quem não } \\
\text { tem é enorme, porém ambos desenvolvem as mesmas funções, com o } \\
\text { mesmo comprometimento, dedicação e agilidade. } \\
\text { - O não reconhecimento pela responsabilidade que carrego. }\end{array}$ \\
\hline $\begin{array}{l}\text { Falta de } \\
\text { profissionalismo/ } \\
\text { colaboração }\end{array}$ & $\begin{array}{l}\text { - Pelo alto volume de serviços e colaboradores, pode acontecer de se destacar } \\
\text { apenas o mais "puxa-saco" ou comunicativo da equipe, e não o mais dedicado } \\
\text { às atividades propostas e efetivamente realizadas. } \\
\text { - A única desvantagem que vejo, e que não me afeta diretamente, é o fato de } \\
\text { trabalhar com algumas pessoas que se sentem melhores que outras, assim } \\
\text { tomo cuidado para não gerar atrito com ninguém e manter o ambiente o mais } \\
\text { confortável possível para todos. } \\
\text { - Equipe desunida. }\end{array}$ \\
\hline $\begin{array}{l}\text { Políticas } \\
\text { diferenciadas }\end{array}$ & $\begin{array}{l}\text { - A empresa adota políticas diferentes para colaboradores: para alguns pagam } \\
\text { periculosidade e para outros, que executam a mesma função, não, ou seja, } \\
\text { há dois pesos e duas medidas. } \\
\text { - Existem funções iguais, de mesma responsabilidade, para cargos diferentes } \\
\text { (na carteira de trabalho). } \\
\text { - Há colaboradores desempenhando as mesmas funções, mas com benefícios } \\
\text { e salários diferenciados, gerando grande descontentamento. } \\
\text { - Divisão desigual de tarefas. }\end{array}$ \\
\hline Local de trabalho & $\begin{array}{l}\text { - Não ter escritório adequado. } \\
\text { - Local para nos reunirmos de forma adequada, tanto para reuniões como para } \\
\text { usarmos Internet e impressora. } \\
\text { - Falta de estrutura física. }\end{array}$ \\
\hline
\end{tabular}

Fonte: Autora.

\section{Quadro 8 - Sugestões para que a empresa se consolide como uma excelente}

\section{empresa para se trabalhar}

\begin{tabular}{|c|c|}
\hline Categoria & Comentários selecionados \\
\hline $\begin{array}{l}\text { Promover } \\
\text { treinamento/ } \\
\text { desenvolvimento }\end{array}$ & $\begin{array}{l}\text { - Para gestores: liderança, gestão do tempo, etc. } \\
\text { - A empresa se transformou em uma grande prestadora de serviços, } \\
\text { adquirindo grandes contratos e se tornando uma empresa responsável por } \\
\text { grande parte do tráfego de voz e dados das operadoras de telefonia no } \\
\text { Brasil. Os colaboradores precisam sempre estar em sinergia com esta nova } \\
\text { realidade e buscar sempre a melhoria contínua nos processos para garantir } \\
\text { a satisfação dos clientes. Quem faz uma empresa de sucesso são as forças } \\
\text { da mão de obra de qualidade. } \\
\text { - Melhorar a questão da oferta de cursos de aprimoramento e capacitação do } \\
\text { seu quadro de colaboradores, ou seja, investir no seu maior patrimônio, que } \\
\text { é o seu quadro de colaboradores. } \\
\text { - Treinamentos de reciclagem. } \\
\text { - Treinamento de outras áreas com certificado. }\end{array}$ \\
\hline
\end{tabular}




\begin{tabular}{|c|c|}
\hline & $\begin{array}{l}\text { - Treinamentos sobre equipamentos que estão sendo implantados na rede } \\
\text { - Das contratantes e instrumentos de medições. } \\
\text { - Dara que hartunidades de acompanhar, no dia a dia, técnicos mais experientes, } \\
\text { - Fazer convênio com universidades. } \\
\text { - Reembolso ou ajuda de custo para cursos e/ou formação acadêmica. }\end{array}$ \\
\hline $\begin{array}{l}\text { Desenvolver } \\
\text { feedback/ plano de } \\
\text { carreira }\end{array}$ & $\begin{array}{l}\text { - Ter um plano de carreira bem definido. } \\
\text { - Sempre avaliar os colaboradores e dar oportunidades de plano de carreira, } \\
\text { pois, assim, o colaborador se sentirá motivado a atentar-se às melhorias e, } \\
\text { caso seja reconhecido, estará demonstrando aos outros que "vale a pena } \\
\text { vestir a camisa". } \\
\text { - Melhorar a forma de avaliação do profissional para proporcionar crescimento } \\
\text { por mérito, e não por indicação pessoal. } \\
\text { - Avaliar: aquisição de conhecimentos (nos processos da empresa e/ou } \\
\text { departamentos), estudos na área, desempenho na elaboração das tarefas e } \\
\text { cumprimento de prazos. } \\
\text { - Ajustar salários de acordo com estudos e conhecimentos adquiridos para a } \\
\text { melhoria do processo da empresa. }\end{array}$ \\
\hline Manter qualidade & $\begin{array}{l}\text { - Acredito que já seja uma empresa de excelência para se trabalhar. } \\
\text { Evoluções serão pontuais. } \\
\text { - Acredito que a empresa está indo no caminho certo, tem um ótimo ambiente } \\
\text { para se trabalhar e abre espaço para colocarmos em prática todo nosso } \\
\text { conhecimento e adquirir muito mais, através das experiências do dia a dia. } \\
\text { - Continuar exercendo o trabalho ético, responsável e eficiente que realiza. } \\
\text { - Manter a qualidade de serviço prestado. } \\
\text { - Garantir bons contratos para prestação de serviço. } \\
\text { - Buscar a excelência e acompanhar as mudanças na área de telecom. }\end{array}$ \\
\hline $\begin{array}{l}\text { Promover } \\
\text { reconhecimento } \\
\text { dos colaboradores }\end{array}$ & $\begin{array}{l}\text { - Pelos gerentes e coordenadores. } \\
\text { - Melhoria de salários como forma de reconhecimento. } \\
\text { - Promover encontros de discussão com debates envolvendo áreas diversas, } \\
\text { estimulando colaboradores com objetivos a serem alcançados e premiando- } \\
\text { os com reconhecimento, seja financeiro ou motivacional. } \\
\text { - Valorizar mais os profissionais que buscam qualificações. }\end{array}$ \\
\hline $\begin{array}{l}\text { Promover } \\
\text { comunicação } \\
\text { interna }\end{array}$ & $\begin{array}{l}\text { - Tornar as informações um bem comum entre as áreas envolvidas. } \\
\text { - Caixa de sugestões permanente. } \\
\text { - Foco no marketing interno/externo. } \\
\text { - Continuar mantendo canal aberto com os colaboradores, para analisar as } \\
\text { - dificuldades e procurar adotar algumas sugestões, que sejam pertinentes. } \\
\text { - Escutar o colaborador nas críticas e sugestões à empresa. } \\
\text { - Fazer com que as informações e as mudanças de planejamento sejam } \\
\text { informadas aos colaboradores, antes das cobranças - somos cobrados de } \\
\text { coisas das quais nem sabíamos que tinham sido alteradas. } \\
\text { - A empresa poderia abrir um centro de interação com pessoas altamente } \\
\text { treinadas para ajudar a solucionar problemas nos sites, onde o técnico é } \\
\text { carente de conhecimento. } \\
\text { - Precisam elevar o nível de satisfação e felicidade de seus colaboradores, } \\
\text { com métodos de posicionamento da empresa entre a equipe, elevando a } \\
\text { comunicação interna ao nível máximo, divulgando informações em primeira } \\
\text { mão e trabalhando sua marca de empregador em conjunto com o pessoal } \\
\text { de marketing. }\end{array}$ \\
\hline $\begin{array}{l}\text { Criar política de } \\
\text { cargos/ salários }\end{array}$ & $\begin{array}{l}\text { - Plano de remuneração de cargos e salários que incentive o colaborador a } \\
\text { permanecer na empresa e, com isso, sua experiência e conhecimento } \\
\text { adquiridos vão garantir uma mão de obra eficiente. } \\
\text { - Colocar em prática a implantação do sistema estruturado de cargos e } \\
\text { salários, deixando tudo mais claro e mais correto. }\end{array}$ \\
\hline $\begin{array}{l}\text { Criar novos } \\
\text { benefícios }\end{array}$ & $\begin{array}{l}\text { - Depositar vale transporte e vale alimentação em dia. } \\
\text { - PLR. } \\
\text { - } 14^{\circ} \text { salário. }\end{array}$ \\
\hline
\end{tabular}




\begin{tabular}{|c|c|}
\hline & $\begin{array}{l}\text { - Plano de previdência privada. } \\
\text { - Pagamento de periculosidade. }\end{array}$ \\
\hline $\begin{array}{l}\text { Considerar opinião } \\
\text { dos colaboradores }\end{array}$ & $\begin{array}{l}\text { - Maior envolvimento dos colaboradores nas melhorias da empresa. } \\
\text { - Fazer acontecer, na medida do possível, as observações dos colaboradores } \\
\text { - Ca empresa, principalmente dos que estão em campo. } \\
\text { críticas. } \\
\text { - Criar mais iniciativas como essa para conhecer a opinião dos colaboradores. } \\
\text { - Pesquisa de satisfação: talvez esse seja o caminho, abrindo espaços para } \\
\text { se ouvir a voz do empregado/trabalhador. Isso é muito bom. }\end{array}$ \\
\hline $\begin{array}{l}\text { Disponibilizar } \\
\text { melhores } \\
\text { ferramentas/ } \\
\text { recursos }\end{array}$ & $\begin{array}{l}\text { - Apoio e fornecimento de equipamentos para que o colaborador possa } \\
\text { realizar um bom trabalho em campo. } \\
\text { - Proporcionar condições de conforto para as equipes de campo, como carros } \\
\text { com ar-condicionado, uniformes e calçados de proteção mais ergonômicos. } \\
\text { - Melhorar a frota. } \\
\text { - Liberar a compra de materiais para uso em campo com mais flexibilidade. } \\
\text { - Disponibilizar bônus para ligações particulares, para agilizar os } \\
\text { atendimentos em casos de emergências, fora do horário de expediente. }\end{array}$ \\
\hline $\begin{array}{l}\text { Promover estrutura } \\
\text { organizacional } \\
\text { eficiente }\end{array}$ & $\begin{array}{l}\text { - Mais gente qualificada, motivada e treinada para fazer o serviço e menos } \\
\text { chefia para criticar e cobrar, sem auxiliar e ajudar nos resultados. } \\
\text { - Menos burocracia. } \\
\text { - Minimizar as dificuldades encontradas em campo. } \\
\text { - Melhorar a logística de material de preventivas e corretivas. } \\
\text { - Ser mais ágil quanto à necessidade dos trabalhadores de campo (materiais, } \\
\text { EPIs, etc.). } \\
\text { - Fazer levantamento sobre onde há maior demanda de serviço e menor } \\
\text { número de pessoal, para que a carga horária dos colaboradores possa ser } \\
\text { reduzida, proporcionando uma condição de trabalho melhor. }\end{array}$ \\
\hline Melhorar a gestão & $\begin{array}{l}\text { - Melhorar a gestão regional: todos estarem envolvidos e participativos nas } \\
\text { opiniões e decisões de maneira que estejam condizentes com a realidade, } \\
\text { isto é, ir ao encontro dos objetivos que foram formatados nos contratos de } \\
\text { maneira coerente. Com certeza, o clima organizacional vai mudar, vamos } \\
\text { nos sentir parte da empresa. } \\
\text { - Líderes com experiências no que fazem. } \\
\text { - Gestores com bons conhecimentos técnicos. } \\
\text { - Maior contato entre diretoria e colaboradores para conhecimento dos } \\
\text { problemas diários. }\end{array}$ \\
\hline $\begin{array}{l}\text { Padronizar } \\
\text { processos }\end{array}$ & $\begin{array}{l}\text { - Evitar a constante mudança de regras. } \\
\text { - Ter procedimentos/processos bem definidos e que sejam aplicados a todos } \\
\text { os projetos. } \\
\text { - Melhorar os padrões de trabalho. }\end{array}$ \\
\hline $\begin{array}{l}\text { Motivar os } \\
\text { colaboradores }\end{array}$ & $\begin{array}{l}\text { - Uma grande empresa não se faz com um grande faturamento, mas com } \\
\text { grandes pessoas. } \\
\text { - Programas para motivar os colaboradores. } \\
\text { - Colaboradores satisfeitos trabalham muito melhor e produzem melhores } \\
\text { resultados. }\end{array}$ \\
\hline $\begin{array}{l}\text { Promover respeito } \\
\text { e qualidade de } \\
\text { vida }\end{array}$ & $\begin{array}{l}\text { - Respeitar mais os colaboradores. } \\
\text { - Melhorar as condições de hospedagem em casos de trabalhos externos. } \\
\text { - Promover a consciência sobre trabalho seguro por parte dos gestores. }\end{array}$ \\
\hline $\begin{array}{l}\text { Divulgar vagas } \\
\text { internas }\end{array}$ & $\begin{array}{l}\text { - Dar oportunidade a quem já faz parte do grupo, e não contratar estranhos: } \\
\text { isso desmotiva, principalmente, financeiramente, pois aceitam pagar muito } \\
\text { mais para uma pessoa que acabou de chegar na empresa do que valorizar } \\
\text { os antigos colaboradores. }\end{array}$ \\
\hline $\begin{array}{l}\text { Ampliar/ melhorar } \\
\text { contratação }\end{array}$ & $\begin{array}{l}\text { - Contratar técnicos qualificados, quando necessário recompor a equipe. } \\
\text { - Ampliar quadro de colaboradores. }\end{array}$ \\
\hline Satisfazer clientes & $\begin{array}{l}\text { - Melhorar o atendimento ao cliente. } \\
\text { - Ouvir o cliente com mais atenção e com maior frequência. }\end{array}$ \\
\hline
\end{tabular}




\begin{tabular}{|l|l|}
\hline & - Garantir a satisfação do cliente. \\
\hline $\begin{array}{l}\text { Estruturar carga } \\
\text { horária adequada }\end{array}$ & $\begin{array}{l}\text { - Escala de folgas efetivas. } \\
\text { - Temos que ter vida social junto à nossa família e amigos. Algumas pessoas } \\
\text { me perguntam se eu trabalho embarcado. Isso tem que ser revisto. }\end{array}$ \\
\hline $\begin{array}{l}\text { Promover RH mais } \\
\text { atuante }\end{array}$ & $\begin{array}{l}\text { - Atuar como RH, e não como DP. } \\
\text { Quando precisamos esclarecer dúvidas, não somos atendidos ou } \\
\text { respondidos por e-mail ou telefone. } \\
\text { Deve ser desenvolvida uma melhor política de RH, com ênfase na } \\
\text { valorização humana. } \\
\text { - Ter um RH estratégico com foco nos colaboradores. }\end{array}$ \\
\hline $\begin{array}{l}\text { Promover melhor } \\
\text { ambiente de } \\
\text { trabalho }\end{array}$ & $\begin{array}{l}\text { - Criar um ambiente melhor para as refeições. } \\
\text { - Melhorar a ergonomia dos colaboradores frente ao computador. } \\
\text { - Investir mais em infraestrutura interna (mesas, cadeiras, armários, baias, } \\
\text { sala de jogos, cozinha mais confortável, local para descontrair, etc.). }\end{array}$ \\
\hline
\end{tabular}

Fonte: Autora. 


\section{APÊNDICE L}

Avaliação de reação dos cursos desenvolvidos como provas de conceito da pesquisa-ação

Esta avaliação tem como objetivo conhecer a sua opinião em relação ao treinamento ministrado pela empresa. Seus comentários e sugestões nos auxiliam no aprimoramento contínuo do conteúdo, metodologia e recursos empregados, permitindo-nos desenvolver treinamentos cada vez mais focados em suas necessidades de capacitação e aperfeiçoamento. Participe!

Escala de alternativas: concordo totalmente; concordo; indiferente; discordo; discordo totalmente

Questões:

1. Meu conhecimento sobre o conteúdo abordado foi ampliado após o treinamento.

2. O conteúdo atendeu às minhas expectativas.

3. O conteúdo tem aplicação prática no meu trabalho.

4. O conteúdo foi abordado com a profundidade necessária às minhas atividades.

5. A sequência de apresentação do conteúdo foi adequada, permitindo-me compreendê-lo de forma gradativa.

6. Os exercícios ajudaram a fixar o conteúdo.

7. As atividades práticas foram valiosas para a compreender o conteúdo e para entender sua aplicabilidade no dia a dia de trabalho.

8. O ambiente virtual de aprendizagem (Moodle) foi adequado.

9. As instruções para acessar a plataforma foram adequadas.

10. A mediação do tutor foi adequada.

11. A interação via fórum complementou o processo de aprendizagem do conteúdo.

12. A explicação do conteúdo foi clara e objetiva.

13. O tutor foi atencioso e prestativo.

14. O tutor mostrou-se disposto a esclarecer dúvidas.

15. Houve momentos para interação com os colegas e com o tutor.

16. Os recursos educacionais utilizados (vídeos, textos, atividades e animações) foram ricos para a compreensão do conteúdo. 
17. Os recursos utilizados permitiram-me "visualizar" a importância dos procedimentos no dia a dia de trabalho.

18. Após o treinamento, sinto-me apto a executar as atividades diárias da minha função.

19. O treinamento foi importante para conhecer a cultura organizacional e o perfil dos colaboradores da empresa.

20. Em caso de dúvidas no trabalho, sei a que/quem recorrer para esclarecê-las.

21. Após o treinamento, estou apto a utilizar os canais de comunicação e os equipamentos disponibilizados pela empresa.

22. Recursos como vídeos, imagens, animações e gráficos auxiliam-me a compreender melhor determinado conteúdo.

23. A leitura de textos e os exercícios individuais são importantes para meu processo de aprendizagem.

24. O uso de recursos sonoros, como músicas, ajuda na fixação de conteúdos.

25. Aprendo mais quando posso interagir e discutir sobre o conteúdo com colegas e instrutores.

26. Considero importantes os cursos a distância e tenho facilidade para participar de um treinamento neste formato.

27. Acredito que o uso de novos recursos educacionais, como os jogos, torna os treinamentos mais interessantes.

28. Considero importante contar com ferramentas online que permitam consultar temas relacionados ao conteúdo e às ocorrências de trabalho a qualquer momento.

29. Considero o deslocamento físico para participação de treinamentos corporativos e de cursos presenciais uma barreira para a realização de novas capacitações.

30. Considero importante a interação constante com colegas de trabalho para solucionar problemas e trocar experiências do dia a dia.

31. Tenho interesse em participar de outros cursos online realizados pela empresa.

32. Tenho interesse em fazer novos cursos que tornem meu currículo mais interessante.

33. Comentários e Sugestões: 


\section{APÊNDICE M}

Quadros com resultados qualitativos das avaliações de reação dos cursos

Quadro 9 - Resultados qualitativos da avaliação de reação do curso de Integração

\begin{tabular}{|c|c|}
\hline Categoria & Comentários selecionados \\
\hline Elogios & $\begin{array}{l}\text { - Curso muito construtivo. Acredito que toda empresa deveria apresentar aos } \\
\text { seus colaboradores toda política da forma como nos foi apresentada. } \\
\text { - Excelente metodologia. } \\
\text { - Estou há pouco tempo na empresa e, até agora, só tenho a elogiar a firma } \\
\text { pela estrutura, pela atenção aos colaboradores e, principalmente, pelas } \\
\text { boas condições de trabalho (ferramental e capacitação de atividades). } \\
\text { - Obrigado à empresa por nos dar oportunidades de crescermos em } \\
\text { conhecimentos profissionais, dispondo de cursos tão importantes para o } \\
\text { nosso dia a dia em campo e para a vida! } \\
\text { - Acredito que a empresa esteja focada na qualidade do seu colaborador e, } \\
\text { com isso, quem ganha somos nós, por sermos profissionais qualificados e } \\
\text { atualizados, em um mercado de trabalho cada vez mais competitivo. } \\
\text { - Gostei muito. Já trabalhei em várias empresas e essa é a única a fazer um } \\
\text { curso deste tipo. } \\
\text { - Dá uma segurança começar a trabalhar sabendo como funciona a empresa. } \\
\text { Parabéns pelo curso. } \\
\text { - Fico grato a toda equipe pela elaboração do treinamento, pois o conteúdo } \\
\text { interessa diretamente às demandas de trabalho. }\end{array}$ \\
\hline Conteúdo & $\begin{array}{l}\text { - Na minha avaliação, foi um curso muito enriquecedor, pois pude dirimir } \\
\text { dúvidas que, até o momento, não haviam sido elencadas, fazendo com que } \\
\text { possamos seguir a diretriz da empresa, sem ter problemas futuros. } \\
\text { - O curso foi bem instrutivo em relação à visão da empresa e aos } \\
\text { procedimentos a serem adotados no dia a dia. } \\
\text { - Curso claro, explicações fáceis e de aprendizado rápido. } \\
\text { - Muito didático. } \\
\text { - Achei o conteúdo bem explicativo, interativo e muito claro. } \\
\text { - Esse curso foi de grande valia, tendo em vista que acabo de entrar na } \\
\text { empresa, pois, além de mostrar nossos direitos e deveres, tem como } \\
\text { objetivo apresentar um pouco da filosofia da empresa. } \\
\text { - Integração muito importante para interação do colaborador com a empresa } \\
\text { - Gua ideologia! } \\
\text { esclei muito dos temas abordados, são de suma importância para } \\
\text { empresa. }\end{array}$ \\
\hline EAD/Moodle & $\begin{array}{l}\text { - Esta ferramenta é indispensável para o aprimoramento do nosso trabalho } \\
\text { no dia a dia, pois nem sempre podemos contar com o auxílio físico dos } \\
\text { colegas e, tendo o fórum à disposição, fico mais à vontade para poder tirar } \\
\text { minhas dúvidas. } \\
\text { - Acho muito importante esta ferramenta de interação e aprendizado da } \\
\text { empresa, pois nos facilita quanto ao tempo para a realização das } \\
\text { atividades, considerando nosso horário diferenciado de trabalho e } \\
\text { flexibilizando a oportunidade de adquirir maiores conhecimentos junto a } \\
\text { empresa. } \\
\text { - A iniciativa da empresa em criar um canal para troca de experiências do } \\
\text { trabalho é ótima. } \\
\text { - As mudanças tecnológicas acontecem, indiscutivelmente, mais rápidas do } \\
\text { podemos realmente acompanhar. Assim sendo, todas as formas, todos os } \\
\text { recursos disponibilizados devem ser aproveitados da melhor maneira } \\
\text { possível, a fim de minimizarmos os impactos que a desatualização pode } \\
\text { provocar na carreira de um profissional. }\end{array}$ \\
\hline
\end{tabular}




\begin{tabular}{|l|l|}
\hline & - Essa é uma excelente forma de estarmos integrados com informações \\
importantes, de forma econômica e no conforto do local onde escolhemos \\
para acompanhar o treinamento.
\end{tabular}

Fonte: Autora. 
Quadro 10 - Resultados qualitativos da avaliação de reação do curso TCP/IP

\begin{tabular}{|c|c|}
\hline Categoria & Comentários selecionados \\
\hline Elogios & $\begin{array}{l}\text { - Iniciativa construtiva, útil e de grande valia. } \\
\text { - Mostra o comprometimento da empresa com o aprendizado e a reciclagem } \\
\text { dos colaboradores. } \\
\text { - Já faço um curso de graduação semipresencial EAD e posso dizer que } \\
\text { nosso treinamento não deixou a desejar. } \\
\text { - Gostaria de parabenizar pela iniciativa dos cursos online, pela importância } \\
\text { do conteúdo no dia a dia, pela reciclagem e pelos conhecimentos } \\
\text { adquiridos. } \\
\text { - Obrigado pela oportunidade de reaprender a aprender! Espero usar este } \\
\text { conhecimento no dia a dia. }\end{array}$ \\
\hline Conteúdo & $\begin{array}{l}\text { - Seria interessante inserir alguns módulos com comandos sobre como fazer } \\
\text { uma configuração em um router ou switch e, também, desenvolver alguns } \\
\text { exercícios a serem realizados no simulador Packet Tracer. } \\
\text { - Melhorar o capítulo sobre Máscara de Rede, explicando melhor a } \\
\text { distribuição dos endereços, mediante o número de máquinas propostas. } \\
\text { - Gostaria de mais detalhamento de recursos, como contas diretas nas } \\
\text { conversões binário/decimal para encontrar o número IP, MASK, da rede, } \\
\text { além de aplicativos de calculadora IP. Gostaria, também, de mais conteúdo } \\
\text { sobre a evolução das categorias de cabos, desde pares trançados até fibras } \\
\text { ópticas. } \\
\text { - Especificar mais detalhadamente os órgãos nacionais e internacionais } \\
\text { relacionados à padronização e à evolução da Internet, bem como siglas e } \\
\text { aplicações. } \\
\text { - Realizar cursos focados nas certificações. } \\
\text { - Seria necessário aumentar a quantidade de material disponibilizado em } \\
\text { cada conteúdo e duração do curso. }\end{array}$ \\
\hline Recursos & $\begin{array}{l}\text { - Sugiro que possamos baixar cada módulo em formato de vídeo contínuo, e } \\
\text { não em fragmentos ou somente em áudio. Com isso, poderemos assistir } \\
\text { offline quantas vezes quisermos. } \\
\text { - Liberação de mais exercícios ou fontes na Internet para que possamos } \\
\text { exercitar mais. } \\
\text { - Deveriam haver mais animações para interações com os usuários, acho que } \\
\text { isso facilitaria o entendimento do conteúdo. } \\
\text { - Gostaria que o recurso de vídeo fosse mais utilizado devido ao fato de todo } \\
\text { o material ser online. } \\
\text { - Como sugestão, destaco a possibilidade de o aluno pausar a apresentação } \\
\text { ou selecionar em qual parte da aula deseja revisá-la de uma forma mais } \\
\text { ampla. }\end{array}$ \\
\hline Aprofundamento & $\begin{array}{l}\text { - Senti um pouco de dificuldade nos últimos capítulos. O conteúdo aplicado } \\
\text { não atendeu às minhas dúvidas. } \\
\text { - Em determinados assuntos tratados, julguei as explicações insuficientes } \\
\text { para a realização dos exercícios propostos, porém considero que o curso } \\
\text { pode ser muito proveitoso, a partir do esclarecimento de dúvidas através de } \\
\text { pesquisas em ambiente externo ao treinamento ou fóruns. } \\
\text { - Alguns assuntos foram abordados de forma simples e cobrados nos testes } \\
\text { de forma complexa. }\end{array}$ \\
\hline Equipe & $\begin{array}{l}\text { - Agradeço aos profissionais envolvidos na construção do curso, desde } \\
\text { abordagem, apresentação, conteúdo e fórum de dúvidas. } \\
\text { - A equipe que montou o treinamento está de parabéns e tenho certeza de } \\
\text { que está buscando melhorar ainda mais para os próximos cursos. } \\
\text { - Alguns módulos são complicados para quem não possui muito } \\
\text { conhecimento, mas com o auxílio do tutor acredito que deu para entender } \\
\text { bem a matéria de cálculo de hosts. }\end{array}$ \\
\hline
\end{tabular}

Fonte: Autora. 


\section{APÊNDICE N}

Descrição dos elementos do jogo sério TCP/IP

- Situação: um técnico de plantão é acionado para resolver o seguinte evento: restaurar o sinal $3 G$ de um site. Se não resolvido, o problema afetará diretamente a transmissão de um jogo de futebol, que ocorrerá no final do dia.

- Personagens: técnico da empresa e atendente responsável por acionar os colaboradores escalados para resolver ocorrências.

- Objetivo principal: restaurar o sinal do site.

- Objetivos secundários: possibilitar a transmissão do jogo de futebol e permitir aos amigos um momento de entretenimento.

- Métricas: resolução ou não da ocorrência; aplicação dos procedimentos da forma mais objetiva e de acordo com o curso TCP/IP; tempo gasto para encerrar o evento: dentro ou fora das estimativas; transmissão ou não do jogo.

- Barreiras e conflitos: tempo, pneu furado e falta de combustível.

- Controle (das barreiras e conflitos): tempo: pode ser controlável ou não, dependendo da falha detectada - o jogador pode "lutar" contra essa barreira, utilizando corretamente o conhecimento apresentado no curso; pneu furado: não controlável, cabendo ao colaborador adotar o procedimento correto quando surgir esta barreira; falta de combustível: controlável, uma vez que é dever do colaborador garantir que o carro esteja abastecido antes do atendimento de uma ocorrência.

- Cadeia de objetivos: escolher os melhores caminhos para chegar até o site; chegar até o site para configurar o IP e acessar o equipamento; acessar o equipamento para fazer os testes e detectar a falha; detectar a falha para resolvê-la; resolver a falha para permitir a restauração do sinal; permitir a restauração do sinal para possibilitar a transmissão do jogo; possibilitar a transmissão do jogo para permitir que os amigos o assistam pela Internet; permitir que os amigos o assistam pela Internet para ser o "herói" da história.

- Recompensas: torres de transmissão: à medida em que avançar no jogo, o jogador receberá torres bronze, prata e dourada; reconhecimento na empresa: por ter resolvido a ocorrência de forma objetiva e de acordo com o tempo estimado; 
reconhecimento dos amigos (emocional): por ter possibilitado uma situação que não seria possível se a ocorrência não fosse resolvida.

- Fases: fase 1 - quatro questões múltipla-escolha sobre procedimentos; fase 2 quatro questões múltipla-escolha conceituais; e fase 3: quatro questões operacionais, sendo duas múltipla-escolha e duas com lacunas para inserção da resposta.

- Game over: o aluno irá refazer a fase. 


\section{APÊNDICE 0}

Avaliação de reação da prova de conceito jogo sério TCP/IP

Esta avaliação tem como objetivo conhecer a sua opinião em relação ao jogo sério TCP/IP. Seus comentários e sugestões nos auxiliam no aprimoramento contínuo do conteúdo, metodologia e recursos empregados, permitindo-nos desenvolver recursos educacionais cada vez mais focados em suas necessidades de capacitação e aperfeiçoamento. Participe!

Escala de alternativas: concordo totalmente; concordo; indiferente; discordo; discordo totalmente

Questões:

1. O conteúdo abordado no jogo relaciona-se às atividades do meu dia a dia de trabalho?

2. A usabilidade do jogo foi adequada, permitindo-me navegar sem dificuldades.

3. A ferramenta de ajuda foi útil para analisar e responder as questões.

4. Senti-me motivado a prosseguir até o final do jogo.

5. As instruções sobre objetivos e missão do jogo foram adequadas.

6. O objetivo final do jogo revela a importância do meu trabalho para a sociedade.

7. A abordagem lúdica deixou as questões mais interessantes em relação aos exercícios de fixação?

8. Gostaria que mais jogos como esse sejam desenvolvidos.

9. Comentários e sugestões 